\title{
CULTURE AND ART: DISCURSIVE DIMENSION IN THE EARLY XXI CENTURY
}

Collective monograph

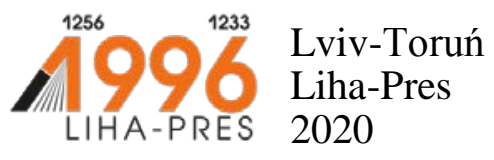




\section{Reviewers:}

Prof. nadzw., dr hab. Stanislaw Kunikowski, Rektor of Cuiavian University in Wloclawek (Republic of Poland);

Prof. dr hab. Kazimierz Pierzchala, Katolicki Uniwersytet Lubelski/Catholic University of Lublin (Republic of Poland);

Prof. dr hab. Stanistaw Juszczyk, Uniwersytet Ślaski / University of Silesia (Republic of Poland).

Culture and art: discursive dimension in the early XXI century : collective monograph / A. A. Genkin, M. P. Kalashnyk, Yu. I. Loshkov, T. S. Ovcharenko, A. P. Ovchynnikova, T. I. Uvarova. - Lviv-Toruń : LihaPres, 2020. $-136 \mathrm{p}$.

ISBN 978-966-397-215-2

Liha-Pres is an international publishing house which belongs to the category „C” according to the classification of Research School for Socio-Economic and Natural Sciences of the Environment (SENSE) [isn: 3943, 1705, 1704, 1703, 1702, 1701; prefixMetCode: 978966397]. Official website www.sense.nl. 


\section{CONTENTS}

"THE AGE OF VIRTUOSOS"

AS A SPECIAL DAY OF EUROPEAN PIANISM

Genkin A. A.

MUSIC THESAURUS COMPILING TECHNIQUE

Kalashnyk M. P.

ORCHESTRAL CONDUCTING:

SPECIFIC NATURE OF FORMATION

Loshkov Yu. I.

PLACE OF THE JEWISH THEATER

ON THE THEATER MAP OF UKRAINE AND ODESSA

(REVIEW AND ANALYSIS OF THE ARCHIVE MATERIALS

OF THE ODESSA PRESS)

Ovcharenko T. S.

SUCCESSFUL SPEECH:

PLANNING AND PREPARATION

Ovchynnikova A. P. .84

FORMATION OF MEDIACULTURE

AS A DIRECTION OF SCIENTIFIC RESEARCH

Uvarova T. I. 
DOI https://doi.org/10.36059/978-966-397-215-2/5-26

\section{"THE AGE OF VIRTUOSOS" AS A SPECIAL DAY OF EUROPEAN PIANISM}

\section{Genkin A. A.}

\section{INTRODUCTION}

The long-term period of birth and the formation of pianism as playing new instrument and the separation of piano and performance practice as a self-sufficient means of musical expression have led to the actualization of the need for the specification of pianism through the development of its own "language", as well as a set of appropriate techniques of motor skills and sound. Therefore, the issue of mastering the instrument, which meant first and foremost the high aesthetic level of piano playing, was on the agenda. As a result, the ideal of "pure" pianism was born, that is, perfection, and professional skill. Thus, pianism grew "from below" from the level of its system, which in this monograph was called basic. All these circumstances contributed to the development of virtuosity, its absolutization and the emergence of its carrier - the virtuoso pianist, which makes it possible to characterize the period of formation of pianism by the expression "era of virtuosos".

Therefore, the aesthetic ideal of the "era of virtuosos" is the "piano" of the performance through the help of pianism; the main carrier of this ideal is the pianist, who is able to act with a high degree of skill within it, creating a specific, aesthetically perfect world of motor and sound plastic. However, along with this ideal and its carrier, the virtuoso pianist, another has emerged, connected with interpretative tasks and more broadly, with the understanding of piano performance in the context of its cognitive capabilities, capable of delivering the most widespread, even comprehensive content. The coexistence of diverse artistic preferences in a single historical plane makes it possible to understand the "virtuoso era" under the sign of "polyphonic" with the asynchronous actualization of its various tendencies. The "hero" of this era, if considered from the inside, still remained a virtuoso pianist, and only in the second half of the nineteenth century he conceded to an interpreting pianist. 


\section{A virtuoso and virtuosity as aesthetic standards of excellence in performing arts}

The concepts of "virtuoso" and "virtuosity" are widely got covered in modern science. Researchers agree that these concepts are firmly stored in the sociocultural use of a vast historical time-space, and the phenomena identified in creative practice and the consumer environment. Since virtuosity is always associated with skill and - in axiological terms - with value as an "uninteresting" activity, O. Belobrova actually identifies it with the category of aesthetic, considering it as a "standard of perfection" ${ }^{1}$. The musicologist does not limit the sphere of virtuosity to the performance, extending it essentially to all kinds of art as its integral part. Because virtuosity thus becomes one of the attributes of artistic creativity, it acquires the value of universality, revealing its presence in various musical styles, both individual and national, and, ultimately, a crystalline imprint of the aesthetics of the "intramuscular sounding" era ${ }^{2}$.

Virtuosity and its virtuoso occupy the virtually stable position in the performing arts. N. Usenko has been a leader of their historical existence since the first half of the XVIII century, linking with the formation of modern-day musical art and its most important "leader" instrumentalism. During this period, as the musicologist notes, there was a type of concert virtuoso, presented by various instrumentalists. Demonstrating their skills in front of the public, virtuosos invented all sorts of game techniques that contributed to the formation of the outside of musical art, its "body". The culmination of this process, according to N. Usenko, is the turn of the XVIII - XIX centuries ${ }^{3}$. The period highlighted by the author coincides with the emergence of the first virtuoso pianists, musicians who have mastered the new instrument both in terms of mechanics and motor skills, and in terms of sound formation, more broadly - a new instrumental sound image. N. Usenko focuses on the hierarchical indeterminacy of pianists among the total mass of

1 Белоброва О. Принцип виртуозности как фактор музыкального стилеобразования // Київ. музикознавство : зб. ст. / Нац. муз. акад. України ім. П. І. Чайковського, Київ. держ. вище муз. уч-ще ім. Р. М. Глієра. Київ, 2003. Вип. 9. С. 38-47.

2 Белоброва О. Принцип виртуозности как фактор музыкального стилеобразования // Київ. музикознавство : зб. ст. / Нац. муз. акад. України ім. П. І. Чайковського, Київ. держ. вище муз. уч-ще ім. Р. М. Глієра. Київ, 2003. Вип. 9. С. 45-46.

${ }^{3}$ Ibid. 
concert instrumentalists and their quantitative small number, naming M. Clementi, J.L. Dusik, J.B. Kramer, J. Jelinek, J. Welfel, D. Steibelt ${ }^{4}$. However, for three decades, as the author writes, "the distribution of forces" among the touring artists has changed radically: the definition of "virtuoso" was now associated with pianists, "whose competitors could only be violinists" 5 .

Therefore, based on the obtained scientific information, in the XVIII and XIX centuries, the virtuoso was a concert instrumentalist who demonstrated to the public "his own person" and not rather than the author of the music ${ }^{6}$. Firmly settled in his busy sociocultural niche, the virtuoso was invariably in high demand in the audience. N. Usenko points out that in the romantic era, the most outstanding pianists, beginning with L. Beethoven and G. von Bülow, recognized the right of the virtuosos to subordinate the author's musical text to their own tasks. This state of affairs allows her to consider the whole of the nineteenth century as the "age of virtuosos"7. Let's clarify that the term "virtuoso" in this historical period means, as can be seen from the above information, "virtuoso pianist", in contrast to its use in relation to all specialties of instrumentalists in the Baroque era.

However, the conceptual difference in the use of the word "virtuoso" in different centuries is not limited to transferring its meaning to pianists, since cultural and historical development created specific conditions for the virtuoso's activity, which gave him new requirements and, accordingly, corrected the concept of virtuosity. Considering this phenomenon from such an angle of view, H. Muradyan distinguishes his baroque understanding, as mostly connected with inventio - ingenuity in the art of improvisation and composition of the organist; manifestation of taste in the design of melisms, the beauty of sound (at certain speed and motor performance) in the game on the harpsichord of the "gallant" century the quality of the piano background and the ability to move fingers on the keyboard of a new instrument at the turn of the XVIII XIX centuries. It is essentially about the variability not only of "cult"

4 Белоброва О. Принцип виртуозности как фактор музыкального стилеобразования // Київ. музикознавство : зб. ст. / Нац. муз. акад. України ім. П. І. Чайковського, Київ. держ. вище муз. уч-ще ім. Р. М. Глієра. Київ, 2003. Вип. 9. С. 45-46.

${ }^{5}$ Ibid.

${ }^{6}$ Ibid.

${ }^{7}$ Ibid. 
instruments in different historical periods, but also of the ideals of virtuosity ${ }^{8}$. Like N. Usenko, H. Muradian focuses on the perception of outstanding artists of romantic piano art by the public: "Of course, today it is unusual to consider Chopin, Brahms or Liszt not composers but virtuoso pianists, however, the historical logic is inexorable in modern times ${ }^{9}$. However, the cited author does not regard the whole romantic era as the realm of virtuosos with the dominant ideal of virtuosity - "pure" pianism. The new direction of history, which divided the XIX century into two major stages in the development of musical culture - the maturation and crystallization of romanticism in the first half of the century and its later stage in the second - contributed to the stabilization of the new ideal of pianism. The focus on virtuosity gives way to the era of interpretation of the masterpiece recorded by the music spread by the publications is coming. Its inviolability "engenders another "cult" - an inspired pronunciation, expression, i.e. intonation ${ }^{10}$. Accordingly, the concept of virtuosity was rethought: "It was no longer aware of the speed and textural complexity, but of the objectivity and subjectivity of the masterpiece" ${ }^{11}$. In other words, the ideal of "finger fluidity" is replaced by the ideal of interpretation, and the virtuoso pianist - the pianist-interpreter. It would be wrong to claim that a virtuoso pianist completely disappears from the concert stage at this time. It must be about the dominance of one ideal of piano performance over another. The antinomy of the virtuoso artist and interpreter, "virtuosity as a conscious demonstration of technique and virtuosity as a means necessary for the realization of deep meaningful tasks" ${ }^{12}$ extends to $\mathrm{H}$. Muradian throughout the history of performing arts. In his piano branch, the musicologist establishes a parabolic movement in which one ideal, the other acquires the role of an aesthetic dominant. In particular, the periods of return of the cult of virtuosity coinciding with the borders, respectively, of the XIX-XX and XX-XXI centuries are distinguished $^{13}$. It is quite obvious that the characteristics of different

8 Мурадян Г. В. Виртуозность как феномен в истории фортепианной культуры : автореф. дис. ... канд. искусствоведения : спец. 17.00.02 / Ростов. гос. консерватория им. С. В. Рахманинова. Ростов н/Д, 2014. С. 8-10.

${ }^{9}$ Ibid. C. 14.

${ }^{10}$ Ibid. C. 18-19.

11 Ibid.

12 Ibid.

${ }^{13}$ Ibid. C.18-21. 
ideals of pianism should not be absolutized. Like any other generalization, in the case of their "application" to specific phenomena, "material resistance" develops. However, reduced to a particular system, they show the heterogeneity of the aesthetic landmarks of pianism within one historical epoch, in this romantic context, which in turn motivates the legitimacy of the separation of two epochalities in it, one of which is marked by the dominance of ideals of "clear" pianism, and the other - by "interpretive" pianism. We conditionally define the first as "the era of virtuosos" by analogy with the name "era of interpretation of the masterpiece", also conditional, assigned to the pianism of the second half of the XIX century by $\mathrm{H}$. Muradian ${ }^{14}$. Its beginning should be referred to the 1780s, and completion - to the 1840s. Accordingly, the creative practice of "father of pianism" - M. Clementi and F. Chopin's innovations serve as the basis for establishing such a framework. In other words, it covers about the last decades of the XVIII century and the first half of the XIX century.

\section{Chronological boundaries of the "era of virtuosos"}

As follows from scientific sources $[1 ; 2 ; 6 ; 7 ; 8 ; 9 ; 14 ; 16-20]$, there were four interrelated processes at that time: the perfection of the instrument, the self-determination of the piano performance, the search for pianistic means of play - from adaptation to the specific sound, and the evolution of the subject of a new kind of instrumental and performing activity - a pianist, endowed with a special type talent, such as virtuoso artist. Thus, the piano set of techniques of motor skills, "fundamental formulas", a special kind of texture, and the phenomenon of a specific piano sound have formed, which together provided the creation of "language" of this creativity, its rhetoric and poetics, developing a solid structure, such as pianism.

We shall consider the raised issues in more detail. The first is the periodization of the "era of virtuosos" and its chronological boundaries. A. Moffa refers to it the time of the historical existence of the first London - pianist school, which activities cover 1777 and the first two decades of the XIX century. The limits set by the author of the London School's activities are motivated, on the one hand, by the sonatas of

14 Мурадян Г. В. Виртуозность как феномен в истории фортепианной культуры : автореф. дис. ... канд. искусствоведения : спец. 17.00.02 / Ростов. гос. консерватория им. С. В. Рахманинова. Ростов н/Д, 2014. С. 18. 
Op. 2 № 2 M. Clementi, which became "a declaration and at the same time a reference point for the formation of the school; on the second, the crystallization in the 1820 s of a single sound ideal of the piano, as a result of which the "instrument of the English model became obsolete" ${ }^{15}$. Therefore, the aesthetic ideal of the pianism itself is somehow related to the technical and acoustic properties of the piano of a particular design.

O. Aleksieiev does not periodize pianism as an interesting phenomenon, but identifies the end of the XVIII - first half of the XIX century, referring to the work by representatives of London and Viennese pianist schools, considering separately the achievements of L. Beethoven, the piano art of F. Schubert, K.M. Weber, F. Mendelssohn, calling them as "Advanced creative trends <...". He further characterizes R. Schumann's piano legacy, the art of virtuosos of the 1830-1840's, F. Chopin, and completes this part of his work with the F. Liszt pianism ${ }^{16}$. It is easy to make sure that the distribution of material in O. Aleksieiev's book in general does not contradict the chronological limits of the "ear of virtuosos" presented by us. Considering the appeal of "pure" pianism as a certain stage of creativity or its obligatory element - is obvious for all, except, perhaps, for F. Schubert, who were named as composers, the legitimacy of their pianism as "era of virtuosos". It is very telling that N. Kashkadamova begins her book on piano music of the XIX century precisely from the art of virtuosos, which is true both chronologically and historically ${ }^{17}$.

I. Boreiko offers another principle of periodization of the piano and performing arts. The researcher proceeds from the common linguistic and epoch-style criteria and considers on this basis the algorithm of the historical movement of pianism. The chronological boundaries of this periodization coincide with the XVII - the verge of the XIX and $\mathrm{XX}$ centuries, thus encompassing almost the entire musical culture of the classic-romantic era. The first, the Clavier period, coincides with the Baroque era, but its inclusion in the process of formation of the piano

15 Мофа А. В. Английские фортепиано и некоторые стилевые черты лондонской фортепианной школы // От барокко к романтизму. Музыкальные эпохи и стили: эстетика, поэтика, исполнительская интерпретация / отв. ред. С. В. Грохотов. М., 2010. С. 149-156.

16 Алексеев А. Д. История фортепианного искусства. Ч. 1 : учеб. для муз. вузов. М. : Музыка, 1967. 286 с.

17 Кашкадамова Н. Історія фортеп'янного мистецтва. XIX сторіччя : підручник. Тернопіль : АСТОН, 2006. 608 с. : ноти. 
and performing arts, albeit on the rights of its prehistory, is justified, according to the author, by the repertoire of the works by J.S. Bach, G.F. Handel, F. Couperin, J.F. Rameau, and D. Scarlatti in contemporary concert and academic practice. Style features of Baroque clavier music polyphonic composition, "unity of affect", "terraced" dynamics; its subject is a universal musician. But most importantly, in the Clavier period, the "tendency towards instrumental neutrality" prevails ${ }^{18}$.

The transition from clavier to piano dates, according to the periodization of I. Boreiko, to the 1760s and 1780s, partly coinciding with the "Age of Enlightenment" and such artistic phenomena as sentimentalism and Viennese classical school. Homophonic and harmonic thinking, clear delineation of texture plans were predominant; the subject of the performance is not completely separated; universalism remains in pedagogy; the design of the piano is not stable; harmonious figures are laid out in a close arrangement; the right pedal is used as an additional means of expression.

Referring to the authority of G. Abert, I. Boreiko exposes the boundaries of the third period: 1782-1812. However, the Russian researcher tends towards a more generalized chronology: the junction of the XVIII - XIX centuries. The most typical is "the figure of the performer-composer, whose creativity is dominated by the performance component" (the author calls M. Clementi and J.L. Dusik) ${ }^{19}$. Pedagogy of this period focuses on the formation of technical skills, in connection with which the genre of instructional etude develops, the manual technique predominate, the texture acquires a characteristic of concert ${ }^{20}$.

The period of the romantic piano, according to I. Boreiko, covers "almost all the XIX century and is characterized by a powerful flourishing of piano performance" ${ }^{21}$. Since the researcher does not distinguish the internal milestones of the piano-performing process in the era of Romanticism, a summary picture of the state of pianism

${ }^{18}$ Борейко И. М. Методика преподавания дисциплины «История фортепианного исполнительства» у студентов-пианистов средних специальных учебных заведений : автореф. дис. ... канд. пед. наук : спец. 13.00.02 «Теория и методика обучения и воспитания (музыка; уровень проф. образования)». Екатеринбург, 2010. С. 12.

19 Ibid. C. 12-13.

${ }^{20}$ Ibid. C. 12.

${ }^{21}$ Ibid. C. 13. 
emerges, resulting in such characteristic features of romantic performance as "through" his subject - a touring virtuoso, - with a pianist, namely with the figure that A. Aleksieiev finds only in the 1830-1840ss, and H. Muradian - in the second half of the XIX century. I. Boreiko completes the periodization by the XIX and XX centuries. Equally significant, according to the researcher, is the emergence of recording devices. Thus, by the criteria of differences of historical periods, I. Boreyko chooses the general purpose orientation of the great musical era, the type of instrument and its perception, the subject of music and performance. With all the cognition of this approach, he does not answer two questions: whether the chronological limits of stabilization of the New European sound system and piano performance coincide, or whether the process of movement of this kind of art from within, represented in its entirety, is synchronized. Considering them, we shall try to outline the contours of the phases of pianism in the "era of virtuosos".

The periodization of pianism in the way of its formation is complicated by two circumstances. The first of these is the stressful nature of the activities of representatives of different schools, each of which contributed to the specialization of piano performance and, as a result, culture. Such synchronization in time of different technological ideas and sound representations complicates the establishment of internal boundaries of the historical process in this field and contributes to the impression of a more panoramic picture, the dynamism of which is caused more by the set of constantly emerging new "nominal" phenomena than by a purposeful single-line movement. The second circumstance is related to the coexistence of at least two main "heroes" of the piano-performance act: according to O. Aleksieiev, composer-virtuoso and virtuosocomposer. In the first case, we are talking about musicians who place the same value on both varieties of musical creativity - composition art and performance - and enrich each other; the second is about the performers who create the repertoire for their performances ${ }^{22}$.

One should also remember that together with $\mathrm{M}$. Clementi and J.N. Gummel, J. Field and D. Steibelt, piano art also included works by L. Beethoven. An exemplary characteristic of the time limits outlined above is contained in $\mathrm{M}$. Chernyavskaya's textbook and its title:

${ }^{22}$ Алексеев А. Д. История фортепианного искусства. Ч. 1 : учеб. для муз. вузов. М. : Музыка, 1967. С. 8-9. 
"Beethoven's Era"23. The scientific literature sometimes expresses doubts about the "piano" of the composer's thinking of the last Viennese classic. Here is what B. Jaworski wrote about this: "Beethoven's stringquartet thinking, and he" instrumented "it for orchestra, singing, or piano." < ..> "In Beethoven's piano sonatas, the composition is based not on the nature of the piano, but on the presentation of the four-voice vocabulary, each of which is similar to a string quartet"24.

Beethoven's understanding of "piano" was shared by representatives of late romanticism - F. Liszt, J. Brahms, S. Frank, who proposed their own decision. However, they showed their aural perception of the instrument and individual approaches to it even when the foundations of pianism, its poetics and the "linguistic" thesaurus had already developed, and the piano and performing arts no longer required a definition of their essence, instruments and artistic and aesthetic boundaries. Another matter is L. Beethoven, included historically and chronologically in the process of the formation of this art. Therefore, if the foresight of the master in terms of going beyond the "pure" pianism is beyond doubt, then his involvement in the formation of this phenomenon needs comment.

As a creative genius of colossal scale, L. Beethoven seemed to be compressed in his pianism, which derives not only from his concert practice, but also from the texts of his piano works, the way that the art of playing the piano and related spiritual and aesthetic beginning passed through the entire XIX century and preceding it for decades. L. Beethoven's piano and creative heritage proved to be a huge potential energy, the kinetic unfolding of which made the history of pianism of a certain time from the "virtuoso era" to the discoveries of F. Liszt, J. Brahms and S. Frank. If, from the very first opus of the piano sonatas, L. Beethoven declares his conception of the piano as an instrument capable of bringing to the audience all the power of his intellect and courage of spirit and, therefore, understands his resources - and opens them! - as a means of creating an adequate content of this kind of sound image, in other genres, it performs a rapid ascent from the tasks of pianism itself to compositional and "human studies". For example, in

23 Чернявська М. С. Піанізм бетховенської доби. Становлення фортепіанної фактури : навч. посіб. до курсу «Історія фортепіан. виконав. мистецтва» для студентів вищ. спец. навч. закл. III-IV рівнів акредитації. Харків : Смугаста тип., 2015. 208 с.

${ }^{24}$ Наследие Б. Л. Яворского : к 120-летию со дня рождения : сб. ст. М. : Гос. центр. музей муз. культуры им. М. И. Глинки, 1997. С. 59. 
piano concerts he quickly departed from the fascination of contemporary authors with the theme of the figurative plan, the demonstration of mastery of the pianist formulas of motor skills to their symphonization, which was a refusal to improvise with a cadence soloist. N. Kashkadamov notes an analogous metamorphosis of L. Beethoven's instrumental style in the genre of variations: "If at first the main principle in variations was the use of varieties of figurative technique, then in the last cycle of the composer, there were 33 Variations on Diabelli's Waltz, op. 120 - the development of all elements of the theme, its melody, harmony and rhythm" 25 .

Numerous variations of the young KM Weber, who created them for his own concert performances as a virtuoso artist, were marked by simultaneous composer and performing intentions. A. Aleksieiev considers the performance style of German early romance the phenomenon of the transition "from the piano letter of the period of classicism to the texture of Leaf pianism". Specifying this thesis, the scientist notes the various game techniques used by K.M. Weber: in addition to homo and arpeggio passages - chords, octaves, double notes, jumps; "pearl nature" - next to "the expected accuracy and bravura of a great concert plan"; the actual piano effects are combined with orchestral sound. N. Kashkadamova unambiguously classifies pianist Weber as a virtuoso, noting therefore his very large, nimble, keyboard-adapted hand, and brilliant technique - both manual and chord, impeccability in performing double notes, unusual ease in performance jumps. In the genre of variations, K.M. Weber moved, like L. Beethoven, from the fascination with the virtuoso interpretation of the genre, "where the method of variation was prompted by a nimble movement of the hand on the keyboard" to the understanding of variance as "meaningful and imaginative transformations of themes". Also, in parallel with his senior contemporary, the German early romantic turned to genre variation, turning the cycle of variations into suites, and each of them into a miniature. However, K.M. Weber has never given up the opportunity to shine with skill, efficiency of presentation of musical material, artistic manner of expression on the instrument. Even in the high genre of sonata, K.M. Weber does not refuse the opportunity to demonstrate his virtuoso features.

25 Кашкадамова Н. Мистецтво виконання музики на клавішно-струнних інструментах (клавікорд, клавесин, фортеп'яно). XIV-XVIII ст. : навч. посіб. 2-ге вид., випр. і допов. Київ : Освіта України, 2009. С. 354. 
It is easy to see that K.M. Weber, unlike L. Beethoven, does not distinguish between concert and variety and serious forms of composition, invariably combining in all genres the commitment to "pure" pianism and a pronounced characteristic as a manifestation of creative imagination. Such a fusion of the performing and composing gift hides the properties of $\mathrm{K}$. Weber's pianism: "<...> the extraordinary emotional brightness of the performance, its "magnetic force“ which undoubtedly subdued the listeners”. N. Kashkadamova considers this a manifestation of an early-romantic performing style, "which painted brilliant virtuosity with 'superhuman pathos' and gave it exaltation and fantasy" 26 .

Continuing the line of division between piano art by K.M. Weber and L. Beethoven, we note two more points. According to M. Cherniavska, the latter organizes the texture with the help of thematic development ${ }^{27}$. He thinks primarily of the categories of composition, subordinating them to the components of "pure" pianism. Metaphorically speaking, when L. Beethoven creates his artistic concepts, his virtuoso pianist "dies". He is not always concerned about the convenience of the performer, the fitness created for playing the piano. Hence, obviously, the pathos of the "accusation" of Beethoven's opuses in "unpopularity", expressed by B. Yavorskyi ${ }^{28}$. K.M. Weber always maintains a syncretis of his hypostasis, never neglecting a virtuoso, "purely" pianistic beginning, though involving in the aesthetically-playful action the characteristics, that is, does not go beyond the immanently pianistic, but colors it with figuratively-theatrical poetic semantic overtones. L. Beethoven is hence closely in the usual means of piano music: proven textural techniques and pianistic formulas, the most aural aura; on the contrary, K.M. Weber fully trusts the established practice, not joining the opposition to it, but continuing the development of ideas contained in it, that is - with all innovations - never losing "piano" thinking.

26 Кашкадамова Н. Історія фортеп'янного мистецтва. ХIX сторіччя : підручник. Тернопіль : АСТОН, 2006. С. 100.

27 Чернявська М. С. Піанізм бетховенської доби. Становлення фортепіанної фактури : навч. посіб. до курсу «Ітторія фортепіан. виконав. мистецтва» для студентів вищ. спец. навч. закл. III-IV рівнів акредитації. Харків : Смугаста тип., 2015. С. 104.

${ }^{28}$ Наследие Б. Л. Яворского : к 120-летию со дня рождения : сб. ст. М. : Гос. центр. музей муз. культуры им. М. И. Глинки, 1997. 155 с. 
The comparative table contained in the above-mentioned book by M. Cherniavska and drawn on the basis of some observations of S. Feinberg gives a clear idea of the isolation of L. Beethoven's piano style from that developed by virtuoso pianists. The type of texture of L. Beethoven's piano music by M. Cherniavska, after S. Feinberg, is called "orchestral and ensemble", which clearly resonates with the content of B. Yavorskyi's observations above. It is characterized by the tendency to overcome the limitations of "piano", the disclosure of the musical idea by means of juxtaposition of themes, the variety of colors, dialogue, the cohesiveness of different registers, the complexity of the pedal, the understanding of the role of the pedal as a means solely used to extend the fingers while extending the fingers clarity in the presentation of thematic material, the possibility of re-commissioning the ensemble without drastic changes in the texture. The type of texture inherent in pianism and piano works by virtuoso pianists is referred to by the named authors as "fortepiano". It is characterized by disclosure of typical properties of the instrument, convey the musical idea with the texture, uniformity of colors, monologue, avoid sharp change of registers, use of the middle of the keyboard, excess technical techniques, use of the pedal outside the finding of the finger on the keyboard, creation of harmonious colors and hidden voices formed by the texture, the inability to transfer the musical text to the conditions of the ensemble without a radical change of the texture.

\section{A "brilliant style" as the specificity of "pure" pianism}

It is quite obvious that the revealed properties of the "piano" texture determine the specificity of "pure" pianism as a performance and instrument of embodiment of the composer's plan, and ultimately, with some adjustment, the immanent structure of the piano and performing arts, its poetics. An intermediate position in the table compiled by M. Cherniavska could refer to K.M. Weber. The "piano" of his texture is undoubted, and his created piano opus will lose a lot when plaid using other instruments. However, the fusion of pianism with the creativity of composer intentions, the characteristic of thinking (let's not forget that K.M. Weber succeeded equally in conductor and opera arts), extramarital impulses that nourish his creative consciousness, stimulate the search for individual intonational-thematic-thematic. Continuing the metaphor proposed above, K.M. Weber does not "die" either as a composer in favor of "pure" pianism or as a virtuoso in composer's intentions. This is 
how the musical style is born, in which pianistic and composer reflections form an indivisible, syncretic unity. According to the musical role of the first half of the XIX century, highlighted by O. Aleksieiev ${ }^{29}$, K.M. Weber can be classified as a virtuoso composer.

Unlike KM Weber, F. Mendelssohn is the least associated with virtuoso piano performance. In cultural and historical memory, his successes in organ and conductor practice have been preserved to a greater extent. A characteristic name the composer gave to one of his works - "Serious Variations", op. 54, which is impossible not to recognize the polemical meaning directed against the virtuoso interpretation of the genre. Still, it would be too careless to dissuade F. Mendelssohn from his general admiration for demonstrating his brilliant mastery of the art of pianism. Significantly, considering his piano legacy under the auspices of "advanced creative tendencies", O. Aleksieiev identifies a quantitatively significant group of works of German romance, written in a fashionable "brilliant style". The scientist attributes to her two piano concerts, "Brilliant Capriccio", "Serenade" and Allegro giocoso, "Rondo Capriccio", a series of etudes $^{30} \ldots$ We shall also mention youthful double concerts with orchestra - for two pianos and for violin and piano, as well as Fantasy, op. 28 and some songs without words. The heir to the London school, the musical "grandson" of M. Clementi, whose pianistic achievements young F. Mendelssohn received "from the hands" of the student maestro Ludwig Berger. by him the piano works on the "mirror" of a certain era - not only in terms of their belonging to romanticism, but also in terms of the mode of consciousness of the "virtuoso era". As with K.M. Weber, the purely aesthetic task of perfect playing the instrument dissolves without rest in poetic and compositional intentions, but is part of the semantic complex of the work, acts as a factor of spiritual-meaningful level. The real school of pianism is a song without the words of F. Mendelssohn, which shows his composer's ingenuity side by side with a specific pianistic expression both intonational-sound, textural, and motor. In masterly passages and sections of F. Mendelssohn's compositions, N. Kashkadamova sees in particular heritable connections with K.M. Weber, and calls "Serious

${ }^{29}$ Алексеев А. Д. История фортепианного искусства. Ч. 1 : учеб. для муз. вузов. М. : Музыка, 1967. 286 с.

${ }^{30}$ Ibid. C. 66. 
Variations" an "encyclopedia of textured techniques" ${ }^{31}$. The last example is illustrative of the fact that its creator thinks in terms of equally compositional and textural-variational development, and pianistic and textured-piano texture, while continuing the line of concert variations of the "era of virtuosos" in the transformed form of poetic. The decades of F. Mendelssohn's creative maturity, when his most innovative works for the piano were being created, coincided with those of the London and Viennese schools, as well as with Paris, which declared itself later. The concert practice of F. Kalkbrenner and A. Hertz, S. Talberg and I. Mosheles consolidated the authority of virtuoso composers and the urgency of social ordering for their performances, which convinces the value and self-sufficiency of pianism as a special way of self-disclosing personality in comparison with composition, in turn, it testifies to a deep rooting in the musical culture of a new kind of art, born by the "era of virtuosos". The multivector process of becoming pianism as a "nominal", specifying basis of piano performance provokes the question of the existence of a single aesthetic ideal of this phenomenon in the considered historical time. Responding thereto, one should keep in mind the multilevel of the aesthetic ideal, just as artistic style is represented in scientific knowledge. It is necessary to distinguish between the aesthetic ideal of the personal-authorial, of a certain pianistic school and of an epochal one. In accordance with the philosophical categories, they can be defined by the concepts of singular, special, and general. Thus, a hierarchical system of subordination is formed, in which each higher degree "removes" the most frequently repeated features of the previous ones, abstracting from the obvious differences. Thus, the London School was famous for its multi-tone sound of the piano, and M. Clementi wanted to see it a worthy rival of the polychrome orchestra, and his student - J. Field sought a quality, which is usually metaphorically defined by the concept of "illusory". J.N. Gummel was famous for its strikingly transparent "pearl" of passages ${ }^{32}$, and virtuosos of the Paris school became famous for "octave kings" ${ }^{33}$.

${ }^{31}$ Кашкадамова Н. Історія фортеп'янного мистецтва. XIX сторіччя : підручник. Тернопіль : АСТОН, 2006. С. 128-129.

32 Алексеев А. Д. История фортепианного искусства. Ч. 1 : учеб. для муз. вузов. М. : Музыка, 1967. С. 17.

${ }^{33}$ Ibid. C. 92. 
K.M. Weber's aesthetic ideal of pianism is seen in the addition of "pure" pianism properties of characteristics; F. Mendelssohn's - in its transformation into one of the composer's (linguistic) expressive means. But over everything, the search for a characteristic piano in all things prevailed - technology, motor skills, vocabulary, adaptive actions, adjustment of the executive apparatus, carcasses, pianistic formulas, sound palette, etc. Without exaggeration, it can be argued that it was an exploration of ways to communicate with the instrument, its unique acoustic and technical potential and the definition of the limits of "piano". Thus, the aesthetic ideal of the "era of virtuosos" consists in the absolutization of "piano" and pianism as such as its achievement and demonstration, gaining spiritual pleasure from the awareness of the infinite possibilities of the creator.

In this regard, an interesting parable that combines the early period of the "era of virtuosos" with its conditionally later stage. In the creative practice of $\mathrm{M}$. Clementi, the principal figure of the London School, the "founding father" of the pianistic cultural tradition, "piano" is still closely connected with the heritage of the keyboardists, on the one hand, the classic acoustic perception of the keyboard instrument in the paint orchestra. From Clementi, the vectors branch that lead to the development of the piano sound palette, in particular, by J. Field, and the chamberliness (saloon), elegance, finesse, and consonant with the clavier works by J. Haydn and V.A. Mozart. Another vector, by contrast, aims at rethinking classicist orchestration to sound density, power, symphonic scale in L. Beethoven. They are all brought together into a single node in F. Liszt, which thus opens the "era of virtuosos" and finds itself after 1847 on its other side. This allows us to offer conditional periodization of the "era of virtuoso", beginning with its prehistory and ending with exhaustion - while maintaining virtuosity as a stable component of the performing arts and its carrier: pianism. Its birth was preceded by a lengthy phase of understanding the prospects for instrumentalism in connection with the advent of the hammer fortepiano. As follows from the treatises of the middle and second half of the XVIII century - C.P.E. Bach, J. Relshhtab, D.G. Türk and others, analyzed by P. Zaslavska, theorists and educators-clavierists paid considerable attention to the differences in the mechanics and sound of old and new keyboard instruments, as well as contact with the latter. They were concerned about the issues of landing on the piano, the position of the hands and fingers on the keyboard, the ratio of the 
elbow and the brush, the movement of the fingers, fingering - that is, adjusting the pianistic apparatus to achieve a musical sound piano background, because, as the author said, the aesthetic ideal of the music of the time as sources of "pleasure for hearing". Accordingly, the piano performer - however, as with his key predecessors and contemporaries required the clarity of the play, that is, the completeness and expressiveness of each sound; an elaborated arrangement which characterized the baroque-classic era of the connection between music and rhetoric; a sense of musical form that consisted of the phrases of phrase, period, larger compositional units and the whole. A register of expressive means was also made: features and possibilities of dynamics, peculiarities of strokes, fortepiano touch ${ }^{34}$.

As we can see, at the dawn of the birth of practical play of the piano and the thought of it, slowly emerged those components of communication with the instrument, which would later form a multilevel system of pianism. It is no less remarkable that the declared or implied, middle and second half of the XVIII century, keyboardists of the performer - to provide aesthetic satisfaction with the means of skill and grace, i.e. through auditory receptors - corresponds with the understanding of pianism in the following to bring the audience the impulse to contemplate the beauty It is significant that the breakthrough in piano playing by $\mathrm{M}$. Clementi and his associates in the transitional period of centuries has remained strong links with the recent past. A. Moffa observes that Londoners use active melismatics along with its reduction, terraced dynamics - with its flexibility, and abstract forms of movement - with their considerable expansion and enrichment. As a result of their activities, "the whole arsenal of diverse piano technique" has developed ${ }^{35}$. Simultaneously with the formation of pianism as an aesthetic-play structure, that is, as special value, its imaginative potential was considered in the interaction with this process. According to the named researcher, the piano technique itself became of great significance for M. Clementi and was a carrier of artistic and aesthetic content.

34 Заславская П. И. Немецкая клавирная педагогика и теория исполнительства середины и второй половины XVIII века : автореф. дис. ... канд. искусствоведения : спец. 17.00.02 «Муз. искусство». Владивосток, 2009. 27 с.

35 Мофа А. В. Лондонская фортепианная школа конца XVIII - начала XIX веков : автореф. дис. ... канд. искусствоведения : спец. 17.00.02 «Муз. искусство». М., 2013. С. 16. 
All this indicates that at the turn of the XVIII and XIX centuries the basic categories and phenomena of pianism were laid, suggesting that L. Beethoven organically perceived the attitudes of the London School with all the independence of his pianistic, and more broadly, fortepiano thinking.

The second period of this era, as we think, dates back to the 1810 1820 ss, that is, the time of early romanticism, the emergence of romantic composers who take on the achievements of "pure" pianism and adapt them to their own creative tasks. K.M. Weber, never losing his taste for virtuosity as such, reveals in it such emotional and imaginative possibilities as admiration for movement, immersion in the cycle of events, boiling of life, carnival fuss. Movement in its "transcendental" forms is included in the arsenal of composer's means of expression. F. Schubert becomes closer the image of the "singing" piano, created, including, by J. Field. It is significant that the Londoners' miniatures in Russia were called "romances"; in the Austrian romance the piano "singing" linked to the song nature of intonation-instrumental vocabulary. In the 1820s, young F. Mendelssohn often combined modern movement with the baroque-classicist formulas of movement, etc. In our view, the influence of pianism on the emergence of romantic style in composer creativity means its stabilization as a system that has proven to be independent, and at the same time open to the enrichment of two varieties of musical art composition and performance, on a parity basis. The possibility of such a view is supported by the observation given above regarding the establishment in the 1820s of a single ideal of "piano" sound.

Bringing pianism to a state of "solid structure", "ready" quality, determines its development in 1830-1840ss. The coexistence of performers who cultivate "pearl" and "octave" play leads to their synthesis in a single space of performance and composer text - a tendency that is clearly evident in the creative practice of the young F. Liszt. This is the way to the future, to the crystallization of the Liszt reform efforts already beyond the "virtuoso era". On the contrary, the innovative transformations in pianism that belong to F. Chopin - with all their prospects up to the conquest of the French Impressionists - can more likely be regarded as a complete implementation of the ideas of the "virtuoso era" and an incredible expansion of their capabilities - as in the plan of "pure" pianism, and in terms of artistic and aesthetic potential. From these perspective, F. Chopin culminates in a process that began with the virtuosos of London - and Vienna - schools, after which 
pianism came to a new stage in its development related to the activities of F. Liszt and his students - G. Bylov, K. Tausig, E. d'Alber and others. The consolidation of the virtuoso era noted by O. Aleksieiev in the piano-performing practice of the pianist-interpreter's role of play can also be confirmed by the end of the XIX century ${ }^{36}$.

Thus, having developed over about sixty years, "pure" pianism held its ground, taking on various forms throughout its formation and evolution. In the most general terms, there are the intra-pianistic (immanent), which carries the meaningful "radiation" of the piano and performing arts, and the extra-pianistic (general and extra-musical). The first of them are based on the preference for perfection and harmony, which index the image of beauty, and the clarity and equality of the game in motor skills (mostly manual) is juxtaposed with the "illusory" sound, which is achieved with the help of textural and pedal means. In the long run, it becomes fascinated with octave technology while maintaining the main condition - the purity and clear articulation of the performing "language". The second form of manifestation of the aesthetic ideal of pianism in the "era of virtuosos", while maintaining its "purity", is aimed at attracting pianistic means to a wider range of spiritual-meaningful and stylistic phenomena. Piano movement and cantilen ("singing") are conceived as a symbolic expression of the two main figurative-semantic spheres of the romantic worldview: play and lyrics, which act on different facets of personal expression. Thus, the "piano", which underlies the aesthetic ideal of "pure" pianism, turns out, on the one hand, the sound emblem of romanticism, on the other the conductor of common linguistic (species) ideas of a certain historical time.

\section{CONCLUSIONS}

Separation of piano art from other varieties of this kind of musical creativity, on the one hand, and composition, on the other, was during differentiation in the artistic consciousness and practical activity of new and old keyboard instruments, which led to the development of another performing instrument, exploration of technical and expressive possibilities of the piano and its improvement, formation of a special sound image, techniques and game formulas. In other words, the named

${ }^{36}$ Алексеев А. Д. История фортепианного искусства. Ч. 1 : учеб. для муз. вузов. М. : Музыка, 1967. С. 92. 
process was marked by the formation of a "solid nucleus" of piano performance, namely, pianism. The solution to this problem was objectively the work of virtuoso musicians who run the concert stage for about sixty years. Despite the heterogeneity of the ways of mastering the piano and comprehending its associated activities, as well as the understanding of the "face" of pianism, a generalizing principle that makes it possible to speak of the "virtuoso era", the aesthetic ideal of "pure" pianism prevails in these years in achieving a higher degree of piano playing. Thus, a "brilliant style", which, in all its unity, took various forms in a particular school or in personal creative practice. For several decades, "brilliant style" has evolved, confronting the romantic at various stages of its formation, penetrating into it and absorbing it, while maintaining its "physiognomic" features. This makes it possible to periodize the "virtuoso era" from prehistory, transitional decades on the verge of the XVIII and XIX centuries, before crystallization and subsequent destabilization until the middle of the XIX century.

The virtuoso ideal of pianism was influenced by the interaction of three processes in the musical culture of that time: the search for ways to achieve the quality of "piano" - from adaptive technologies to sound, perfection of the instrument itself, the formation of the piano-performing profession, and art as a special, autonomous aesthetic and cultural activities. The emerging specialization was personified primarily by the figure of a virtuoso pianist. The combination of these processes determined the emergence of the cult of "pure" pianism, whose domination period in performance practice - from the late XVIII century untill the 1830s-1840s - created the "era of virtuosos". In parallel with its leading trends, partly collided with them L. Beethoven, a courageous genius who made a powerful breakthrough in the future, developed his pianistic practice, supplying the creative imagination of such giants as F. List and J. Brahms, as well as musicians. Thus, along with the ideal of "pure" pianism, another appeared - an interpretive one that began to dominate in the second half of the XIX century. The presence of the two named ideals of pianism led to the establishment of criteria for their differences concerning, including the type, means and purpose of communication, the pianistic role, the type of personal expression. The rapid emergence of pianism as a new kind of instrumentalism led to a certain algorithm of this process, allowing to create its periodization. The first period coincided with the years of vivid activity of 
representatives of the London School, led by M. Clementi, the second with the creativity of the early romantics, and the third - with the achievement of "pure" crystalline pianism, including F. Chopin's one.

\section{SUMMARY}

The article considers the pianism of the virtuoso era as a carrier of the aesthetic and performing component of piano activity. It is proven that the theoretical aspects of the study of pianism are associated with the understanding of virtuosity as a factor in pianistic mastery.

\section{REFERENCES}

1. Алексеев А. Д. История фортепианного искусства. В 3 ч. Ч. 1, 2 : учебник. 2-е изд., доп. М. : Музыка, 1988. 415 с.

2. Алексеев А. Д. История фортепианного искусства. Ч. 1 : учеб. для муз. вузов. М. : Музыка, 1967. 286 с.

3. Белоброва О. Принцип виртуозности как фактор музыкального стилеобразования // Київ. музикознавство : зб. ст. / Нац. муз. акад. України ім. П. І. Чайковського, Київ. держ. вище муз. уч-ще ім. Р. М. Глієра. Київ, 2003. Вип. 9. С. 38-47.

4. Борейко И. М. Методика преподавания дисциплины «История фортепианного исполнительства» у студентов-пианистов средних специальных учебных заведений : автореф. дис. ... канд. пед. наук : спец. 13.00.02 «Теория и методика обучения и воспитания (музыка; уровень проф. образования)». Екатеринбург, 2010. $23 \mathrm{c}$.

5. Заславская П. И. Немецкая клавирная педагогика и теория исполнительства середины и второй половины XVIII века : автореф. дис. ... канд. искусствоведения : спец. 17.00.02 «Муз. искусство». Владивосток, 2009. 27 с.

6. Заславский И. И. Клавирное исполнительство и педагогика Англии второй половины XVIII века (на материале трактатов и школ) : автореф. дис. ... канд. искусствоведения : спец. 17.00.02 «Муз. искусство». Л., 1990. 25 с.

7. Кашкадамова H. Історія фортеп'янного мистецтва. XIX сторіччя : підручник. Тернопіль : АСТОН, 2006. 608 с. : ноти.

8. Кашкадамова Н. Мистецтво виконання музики на клавішнострунних інструментах (клавікорд, клавесин, фортеп'яно). XIV-XVIII ст. : навч. посіб. 2-ге вид., випр. і допов. Київ : Освіта України, 2009. 416 с. 
9. Мелешкина Е. А. Становление пианизма в контексте развития европейской музыкальной культуры // Учен. зап. Рос. гос. соц. унта. 2012. № 10. С. 146-148.

10. Мофа А. В. Английские фортепиано и некоторые стилевые черты лондонской фортепианной школы // От барокко к романтизму. Музыкальные эпохи и стили: эстетика, поэтика, исполнительская интерпретация / отв. ред. С. В. Грохотов. М., 2010. C. 149-156.

11. Мофа А. В. Лондонская фортепианная школа конца XVIII начала XIX веков : автореф. дис. ... канд. искусствоведения : спец. 17.00 .02 «Муз. искусство». М., 2013. 26 с.

12. Мурадян Г. В. Виртуозность как феномен в истории фортепианной культуры : автореф. дис. ... канд. искусствоведения : спец. 17.00.02 / Ростов. гос. консерватория им. С. В. Рахманинова. Ростов н/Д, 2014. 26 с.

13. Наследие Б. Л. Яворского : к 120-летию со дня рождения : сб. ст. М. : Гос. центр. музей муз. культуры им. М. И. Глинки, 1997. $155 \mathrm{c}$.

14. От барокко к романтизму. Музыкальные эпохи и стили: эстетика, поэтика, исполнительская интерпретация / отв. ред. С. В. Грохотов. М. : Моск. консерватория, 2010. 288 с.

15. Усенко Н. М. Фортепианное виртуозное исполнительство XIX столетия // Международный научно-исследовательский журнал. 2014. Вып. 11, ч. 3. С. 92-94.

16. Чернявська М. С. Епоха романтизму в фортепіанній музиці (до проблеми різноманіття фортепіанних стилів XIX століття) // Теоретичні питання культури, освіти та виховання : зб. наук. пр. / Нац. муз. акад. України. Київ, 2002. Вип. 20. С. 186-191.

17. Чернявська М. С. 3 історії формування фортепіанної фактури // Культура України : зб. наук. пр. / Харків. держ. акад. культури. Харків, 2001. Вип. 8 : Мистецтвознавство. С. 144-152.

18. Чернявська М. С. Л. ван Бетховен і фортепіанна культура кінця XVIII - початку XIX ст. (проблема формування фортепіанної фактури) : автореф. дис. ... канд. мистецтвознавства : спец. 17.00.03 «Муз. мистецтво». Харків, 2001. 19 с.

19. Чернявська М. С. Муціо Клементі: «Прогрес фортепіано імітація оркестру...»// Культура України : зб. наук. пр. / Харків. держ. акад. культури. Харків, 2000. Вип. 6 : Мистецтвознавство. C. 149-158. 
20. Чернявська М. С. Піанізм бетховенської доби. Становлення фортепіанної фактури : навч. посіб. до курсу «Історія фортепіан. виконав. мистецтва» для студентів вищ. спец. навч. закл. III-IV рівнів акредитації. Харків : Смугаста тип., 2015. 208 с.

\section{Information about the author:}

Genkin A. A.,

Candidate of Art Criticism,

Elder teacher of «Fortepiano. Orgel», Dnipropetrovsk M. Glinka Academy of Music 10, st. Foundry, Dnipro, 49000, Ukraine 
DOI https://doi.org/10.36059/978-966-397-215-2/27-44

\section{MUSIC THESAURUS COMPILING TECHNIQUE}

\section{Kalashnyk M. P.}

\section{INTRODUCTION}

Before presenting the scientific provisions that form the theoretical basis of this subsection of our study, let us note that knowledge about music penetrates the consciousness of society and the individual in all ways accessible to a person: from image-subject with direct contemplation or perception of artistic word - to abstract-scientific. However, the very multichannel communication with musical knowledge causes the urgent need for it to be reduced to a single, compact enough document. The music thesaurus takes on this role, the creation of which becomes especially relevant in the context of the present information boom.

The music thesaurus is a document where the meaningful (informational) space of this type of art is implemented through a system of words, concepts organized in the framework of music theory and practice, in a certain organized and presented way. Subject to the complexity of musical knowledge, the ambiguity of the very concept of "music", the variety of forms of its existence, as well as the large number of related activities, it is possible to invest in the used term "information space" the content that its scholars use on a geopolitical scale, noting, in particular, that it is "the only, holistic social information phenomenon that can be considered as a set of interacting information processes and systems $<\ldots>^{\prime 1}$.

The procedure for the creation of thesauruses is described in detail in the Techniques developed by the Institute of Informatics and set out in special editions of the State Standard of Ukraine. ${ }^{2}$ We shall refer to the main provisions of these documents. The structure of a thesaurus is predetermined by its purpose: to give a brief systematic view of a

1 Berestova T.F., Information space as a result of informational process development / T.F. Berestova, Bulletin of MSUCA. - 2005. - No. 3. - P. 112.

2 State Standard of Ukraine. Information and documentation. A multilingual thesaurus: the development methodology. - Official edition - K.: State Standard of Ukraine, 2001. - 76 p. 
particular field of knowledge or practice. Compression involves, first, the reduction of a large number of phenomena to unity through their comprehension with the help of a token; second, the choice of a nonarbitrary meaning. The following claim is laid to the terms that specializes the thesaurus: "Unlike the terms in the dictionary, which can be accompanied by a number of different definitions that reflect common usage, each term of the thesaurus is rigidly tied to a single meaning that best meets the requirements of the indexing system" ${ }^{3}$. Thesaurus is a structure consisting of lexical concepts with certain relationships established between them. There are two types: a posteriori (syntagmatic, conveying the meaning of the phenomenon in a set of terms), and a priori (paradigmatic, assuming the presence of other terms). The latter are to be processed in a thesaurus ${ }^{4}$. In other words, a thesaurus "reproduces through its structure relationships that generally establish the "semantic context" of a given term, with specific references to terms with a broader or narrower connotation (additional meaning). This is usually enough to indicate a scientific interpretation of a particular term ${ }^{5}$.

An important feature of a thesaurus that distinguishes it from unstructured lists of terms, such as a dictionary, is its hierarchy, which means generic, whole-part relationships, and intance ${ }^{6}$. Finally, if the same phenomenon or concept can be defined by different synonymous terms, the most common one should be chosen ${ }^{7}$.

The above recommendations for the compilation of a thesaurus are of a general methodological nature, therefore they require appropriate mediations for their practical application in artistic creativity, and especially in such "meaningless" area as music. This is all the more important because the terminological apparatus of the humanities itself assumes a rather high degree of ambiguity and even metaphoricity. One should not forget the practice of transferring lexical concepts from one art or related discipline to another, adaptation of terminological units of philosophy, literary studies, linguistics, etc. in the content field of music science, as a result of which they acquire new semantics until a complete

${ }^{3}$ State Standard of Ukraine. Information and documentation. A multilingual thesaurus: the development methodology. - Official edition - K.: State Standard of Ukraine, 2001. - P. 7.

${ }^{4}$ Ibid. - P. 1-2.

${ }^{5}$ Ibid. - P. 16.

${ }^{6}$ Ibid. - P. 26.

${ }^{7}$ Ibid. - P. 7. 
rethink (well known examples). Thus, the question arises to the equivalence of twin, chameleon words that travel across different contextual spaces and require assistance in their proper placement in a thesaurus with regard to their formulations, through which they will be embedded in a conceptual system of knowledge. The above is very important for the fundamental terms, concepts of the art disciplines, namely, artistic direction, genre, style, method, etc., which in each of them have their own set of connotations and have different subject expressions. It should also be borne in mind that music is in direct contact with the natural and man-made habitat (acoustic phenomena of nature and civilization), linguistic communication (intonation, melody, phonetic properties of verbal language), as well as the key parameters of being (space and time), reproduced by ancient Greek thinkers in a concept-image of the music of the spheres. Saying nothing of the very nature of sound: it is studied by physics - science, far cry from the phenomenon of art. Thus, the music thesaurus should contain concepts through which at the same time the specificity of music would be revealed as a form of art and a way of indirectly engaging and broadcasting information about the structure of the culture and the universe itself.

\section{The superstuctural level of a music thesaurus}

Before making some constructive suggestions for creating a music thesaurus, we need to come up with some general guidelines. The starting point in our search for the most optimal approach to compiling a list of music-related concepts related is to understand the thesaurus simultaneously as a way of capturing (storing) it in a special form of knowledge itself, as well as encoded information about it, as a key to musicology, which is understood quite widely. In the second case, it is related to the alphabet of the verbal language or the musical sound scale of musical art, both in tempered and non-tempered tuning systems. Adding the initial moment of immersion in a certain sign system, its minimal units formed in a given order make an "elementary" level of knowledge, if we consider this concept synonymous with fundamentality rather than with primitiveness. In the same semantic section, the "primacy" of a thesaurus should be interpreted as a reduction to the system of terms of all the variety of knowledge that has arisen in sociocultural and scientific practice. 
The task of embracing the content of the music thesaurus determines the preference for a morphological approach, which, in turn, presupposes a thematic principle of arrangement of material subordinate to the hierarchical system of relationships in the course of cross-linking. In other words, encyclopedic coverage of information seems to be close for us, however, without alphabetical order and without explanatory remarks and, moreover, without detailed articles. According to the structure of a music thesaurus, the dictionary includes three levels of concepts: "superstuctural", "basic", and one that appeals to the musical-sound realities of routine life ("background"). The first combines concepts contained in the fields of science, education, enlightenment, sociocultural ways of existence of musical forms, that is, with those fields of activity that are powered from music, but do not directly belong to its "body". The "basic" level of knowledge otherwise implies immersion in the music plane and comprehension of music as a phenomenon. The mediators between the "top" and "bottom" of the emerging structure are the individual activity forms associated with the creation of notationgraphic and sonar-background text. The composer and performer "shape" the musical fabric, control its movement, and are involved in the mysteries of musical being, but also exist outside it (the fabric), rather simulating a complete dissolution in it, which should be understood only metaphorically. The musical-sound environment creates the acoustic atmosphere of the present and is confronted with the phenomenon of the musical as a conductor of the non-musical, which feeds the music with immediate life impressions and implements its cognitive function.

Since the 'superstuctural' layer of the thesaurus refers to the knowledge gained in connection with music, it is advisable to group the first subject block around the keyword 'science'. Words combined thereunder can be alphabetical and meaningful. In the first case, they form a simple series, and in the second, - a system of relationships that is preferred to the thesaurus dictionary. Based on the above, the registry of "science" should be headed by the fundamental branches of musicology: music theory with deciphering (elementary theory, harmony, polyphony, instrumental studies, analysis), as well as its history, including the history of orchestral styles, study of local lore, and archival studies. Considering that musical art is not limited to composer work and includes performing arts, it is necessary to add to the third line of the list of terms of this block the discipline title "Theory and History of Performing Arts" with its partial divisions (history of pianism, playing the string, wind, percussion instruments, as well as vocal, orchestral, conductor, capella, choral and 
other arts). In our opinion, fundamental subjects are also the pedagogy and teaching methods of musical subjects (theoretical, historical, performing). Given the active development of the contemporary stage of musical liturgy due to the ever-growing interest in the spiritual-singing templar art, it can also be considered as a fundamental field of science. This also includes folklore treated as a methodological basis for the study of specific realities and the phenomenon of oral folk music-aesthetic worldview. Other areas of science, which are more or less established, are a combination of specifically musical and other problems. Musical semiotics, semantics, psychology, sociology, aesthetics, and philosophy of music have emerged at the intersection of different scientific disciplines. The latter two are maximally abstracted from the "body" of music by virtue of their appeal to the highest, generalized conceptual layer of cognition, thereby bringing musicology to the sphere of philosophical problems. This register of terms would feasibly include scientific and source studies, which make it possible to understand, on the one hand, the regularities of the movement of knowledge about music, and, on the other, to systematize their greater achievements. Bibliography is a special instrument of music science as an instrument for solving this problem. It is no exaggeration to say that this part of the "science" registry forms a bundle of affiliated lines of musicology, the number of which is easy to increase.

Following the laws of logic, the second thematic block of the thesaurus should be devoted to education, i.e. to the institutions where the knowledge of music is transmitted. At the same time, given the specific information and sound nature of music, which determines its existence in two forms (oral and written), the field of education is aimed at acquiring performing professionalism, that is, the instrument or voice mastering skills. Higher music education is taken as a basis, so this part of the register should be legally occupied by higher education institutions: conservatories, academies of music (music academy), institutes of arts, music and drama institutes, music and pedagogical colleges (universities, institutes), universities of arts, universities of music, departments of pedagogical institutes and universities. The list of these educational institutions can follow both hierarchical and alphabetical principle of naming. This part of the register is associated with the words-meanings of secondary and elementary specialized and non-specialized education units: children's music school (CMS), a a study group, an art lyceum, music classes in a secondary school, a music school, a ten-year music school. 

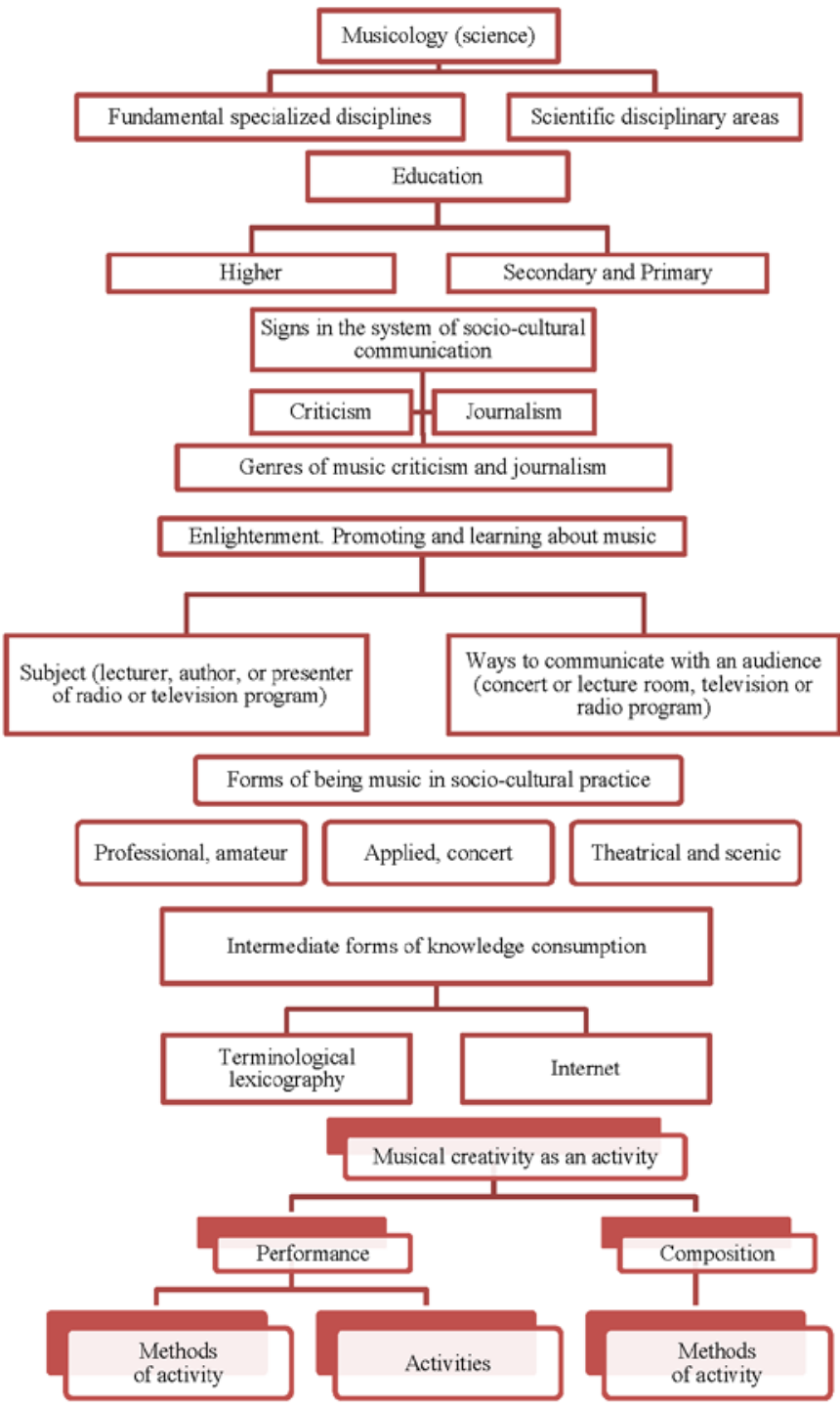

Means of storage of musical knowledgectice

Sheet music and books (handwritten and published texts in hooks, snares, banners, etc.)
Book and record libraries
Audio and video

Figure 1. The superstuctural level of a music thesaurus 
Given that music functions in a particular communication system, music criticism and journalism belong to the third thematic block. Both of these activities brought to life an extensive system of genres, the names of which should appear in the thesaurus (a survey, abstract, problematic article, review, creative portrait, booklet, interview, radio and television broadcast, etc.). Bearing in mind that these disciplines may be related to music science, it is advisable to use the experience of K. Schneider's Thesaurus and provide a "see also" note here, thus sending the user to the first thematic block of the dictionary.

As the attention of music criticism, and especially of journalism, is drawn directly to the public's need for works of art, it may be considered natural to move to a group of terms that they have formed about education (the fourth thematic block). It includes the concepts "lecturer", "popular lecture", "lecture-concert", "preface". This content line has relation to music journalism, so again, the "see also" note is appropriate.

We should note that the possibility of assigning the same words to different headings demonstrates the presence of horizontal and cross-link relations next to vertical ones, which makes the structure of the thesaurus more multidimensional. The above applies not only to individual terms within the registers, but also to the names (verbal designations) of thematic blocks. Thus, "Enlightenment" intersects, on the one hand, with "Science" and "Education", and on the other - with different forms of music being in socio-cultural practice.

The fifth thematic block contains secular and spiritual, professional and amateur, applied and concert, as well as various theatrical and stage ways of implementation of musical creativity.

The intermediate position between cultural and scientific consumption is occupied by the sixth thematic block, which includes various reference and encyclopedic editions: various dictionaries, music lexicons, mono- and multi-volume encyclopedias, the Internet system.

As far as the subject point of view is concerned, music implies, in addition to scientific or amateur knowledge of it, artistic creation itself the seventh thematic block, which in turn is divided into two large subgroups. One of them - "performance", includes the terms "reproduction", "interpretation", "improvisation", defining the content of performing activities, as well as the concepts of "performing style", "school", "tradition" - terms in the field of professional culture. The same group includes performances (solo, ensemble, choral, orchestra, vocal and instrumental) with their consecutive names (duet, trio, quartet, quintet, sextet, septet, octet, nonet; jazz band, rock band, VIA; "triadic music", 
etc.). The second subgroup includes the concept of "music making" - it means "production" of original works (opuses), "improvisation", "harmonization", "arrangement", "transcription", "instrumentation", "orchestration". There are also cross-links between these subgroups. First, the history of music knows several examples of combining in one person the performer and the composer - up to the considerable rethinking of his own opus in the concert program, as, for example, was characteristic of S. Rachmaninov; secondly, performers, including heads of choirs and orchestral teams, successfully manage the harmonization or translation process; and, finally, in the third place, such a form of activity as improvisation can equally belong to the performance as well as to the creation, since in the course of its implementation the musician simultaneously "composes" the intonation-sound text and offers it to the audience. We should add that when creating in the genres of etude, concert, transcription, fantasy, etc., the composer often pursues not only his own compositional and dramatic goals, but also provides for performing, which allows the instrumentalist to demonstrate virtuosity. Similarly, the opera composer often densely captures bellicose roulades into the text of the aria, saturates the tunes with broad jumps, extends the soundtrack, relying on the attention of the diva. At the same time, the author of the musical works does not lack the desire to demonstrate his own skill, ingenuity in creating unique samples of art, introducing unexpected sounds, methods of development, unexpected intonational, structural combinations, etc. In other words, specific artistic tasks, demonstration aspects of creativity that bring together the art of composition and performance may come to the fore. However, we should not forget about the equal desire of the author of musical works to summarize his own observations on the intonational and logical patterns of music, as evidenced by more than one generation of theorist composers who have created many epochal in their significance of scientific works: from "Treatise on Harmony reduced to its natural principle" by JeanPhilippe Rameau to "The Moving Counterpoint of Strict Letter" by S. Taneev. Thus, another link is found between the various thematic blocks of the music thesaurus vocabulary, and more broadly, between the various concepts grouped around the generic term "music".

Performing and composing forms of activity naturally require a transition to their carriers. These include musicians who work in various fields of creativity. In the academic tradition, this is, in particular, the instrumentalist, vocalist, choir or orchestra artist, bandmaster, conductor, composer, arranger, harmonizer (translator: for example, in temple 
singing), etc. In the folklore tradition, representatives of various national professional singers-narrators (akin, kobzar, guslar, etc.), participants of calendar and ceremonial activities, individuals involved in daily affairs, and others can be named. In various forms of so-called light music, we can distinguish jazzmen, rock musicians, creators of the song or its performers, members of the ensemble, etc.

Performing and composing products are stored and transmitted through various means of communication and technology: in oral form (word of mouth), visual-written, book (music, mute, hooks, banners, special marks in music of European avant-garde), audio and video. This is the eighth block of terms, which puts all the previous ones at risk. These include repositories of scientific knowledge (books), periodicals, as well as music and record libraries. It should be recalled that the reference books were discussed above, and they found their place in the second block, given their direct relation to the education sector. Concerning scientific, educational literature and periodicals, they correspond at the same time with the ways of storing knowledge and production: the creation of music, its study and the transfer of experience. Thus, the entire structure of the "superstructure" part of the thesaurus is symmetrically rounded, closing the top and bottom levels of cognition.

To visualize the proposed hierarchical structure, we present its specific system of relationships using the scheme below (Fig. 1).

\section{The "basic" part of the music thesaurus}

The "basic" part of the music thesaurus consists of two subdivisions. The first of these can be called "Music as Art" and the second - "Music as Phenomenon". It opens this hierarchical pyramid of the concept of "music", which combines a large number of manifestations of musical. In particular, it is the music of the academic tradition, folklore, varieties of entertaining types of music, author's song, city romance, etc. The conditional name of the first thematic block - "Music and Musicians". Already, there is a clear heterogeneity of meaningful content of the concept of "music". For example, in folklore, music is almost invariably fused, first, with a word or dance, and, secondly, with some practical action: routine or ritual-magical. It should be clarified that this is about the folk creativity of the oral tradition in its original habitat, and not as a folk ensemble on the concert stage. Similarly, pop genres are most often associated with singing, that is, again with the verbal series, and in modern practice - with dance, not to mention that the entertainment 
subculture does not exclusively involve listening experience, easily turning into dance accompaniment or even a means of creating a particular atmosphere for leisure at home or at the disco. As for academic music, it is also willing to come into contact with non-musical modes of expression with preserving its "name", as is often the case, for example, in the name of "vocal" music, where, quite naturally, the word is involved. This requires the selection of the second thematic block of the "basic" level of the thesaurus, which is conventionally defined as "Quality states of music". It includes so-called "pure" music, that is, that exists without the participation of non-musical factors; program, accompanied by a verbal subtitle, which refers us to all kinds of depicted, literary, landscape and other realities of the artistic and natural environment; theatrical (including music for dramatic performance), cinema, and word-related. In turn, the interaction of the musical and the performing arts has undergone multiple changes over the course of the historical development, and as a result, they can be incorporated into the context of both the musical and theatrical thesaurus. For example, in opera, the main component of synthesis is music, and in a play, even with a developed musical series, on the contrary, it is a performance (in "theater of show" - acting).

Thus, the first two thematic blocks decipher the range of meanings that are included in the generalized notion of "music". Another criterion for its differentiation the aesthetic factor acts in is revealed in evolutionary projection. It is linked to the third thematic block of the thesaurus, covering the general categories of art: artistic trends and historical (landmark, national, individual) styles. If the complete list of the former can be regarded as quite acceptable to the thesaurus due to the relatively small number of names, then among the latter only large epochal phenomena can be distinguished, which nominally coincide with the artistic directions. With regard to national and, moreover, individualauthor styles, this series is headed for virtual infinity, so it cannot claim even relative exhaustiveness.

A number of general aesthetic categories continues the fourth thematic block: genres. Given that this concept has a dual meaning in the music of the academic tradition and related scientific knowledge the type of work and the primary manifestations of the musical, inseparable from material practical activity, it is advisable to distinguish two lists of terms, one of which was formed in line with the New European professional "Written" music, and the second entered it from the outside, from the amateur, folklore and urban living environment and 
sowed in the "high spheres" of musical art an equal place. However, given that the primary genres are originally applied or semi-applied, it is appropriate to duplicate this list in the third block of the thesaurus with a "see also" note.

In listing the genres of academic music, it is best to adhere to the hierarchical principle of arrangement of concepts in accordance with their sequence under the generic "names" of "pure", programmatic, etc. music, adhered to in the second block of the "basic" layer of the thesaurus, which first lists the genres of "pure" instrumental music, then - programmatic, etc. In this case, it is appropriate to exclude the term "music for dramatic performance" that has no genre content. It should be noted, by the way, that this kind of musical art, as well as cinematic music, can also be attributed to the third, background, level of the thesaurus since under such conditions it acquires an applied value.

Given that the equivalent of "pure" music is the instrumentalism of the academic tradition, the largest fifth block of terms combined by the name "Performing Forces" should be headed by the "Orchestra" heading with the decipherment "symphonic", "chamber", "string", variety"," variety and symphony”, "jazz orchestra”, "folk instrumental orchestra”, "baroque instrumental chapel", as well as determining the composition of each. Behind it is the section "Chorus" with clarifications (female, male, children's, mixed, boy choir). These registers are supplemented by lists of "Other instruments" and "Vocal roles". Here again the question arises as to the exhaustibility of the titles of first and foremost instruments that are virtually indistinguishable. A great degree of completeness of information is provided by vocal roles, a number of which are available for review.

The next, sixth thematic block contains the concepts "composition", "dramaturgy", "musical forms" under the general name "Logical laws of the musical text organization". More detailed deployments require "Musical forms", which mention the main, located from complex to simple: cyclical ("sonata-symphonic", "suite", "party", "small", "variational", "concert" forms), contrasting component, sonata, rondo, couplet, two and three parts, period, as well as baroque specimens ("invention", "fugue", "fugato", "concert", etc.).

The methods and ways of musical presentation and development are called expositional, developing, motive development, variant-variational development, imitation, counterpoint, subheading, contradiction, canon, stretto. They include terms that denote sections of the form, such as "exposure", "development", "reprise", "episode", "trio", “interlude”, etc. 

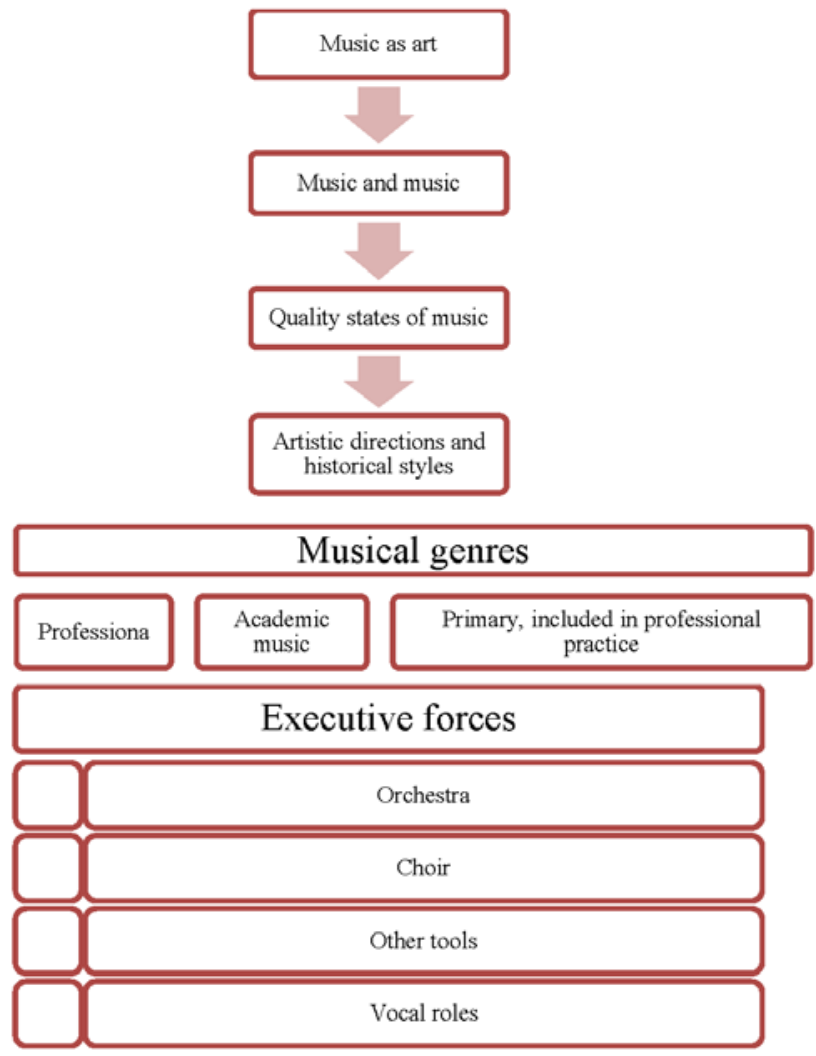

Logical patterns of organization of musical text

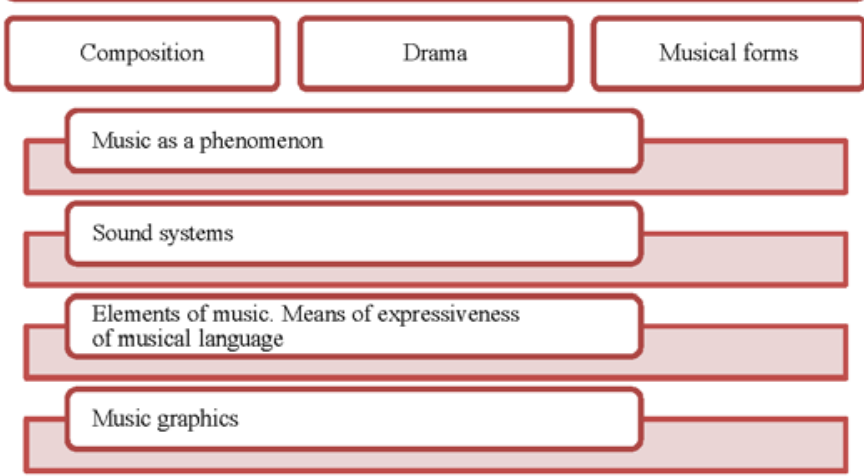

Figure 2. The basic level of a music thesaurus 
As we can see, the first section of the "basic" level of the thesaurus makes a consistent transition from more general, even non-specific, concepts to more specific, musical ones. The conceptual apparatus presented in the last thematic block transfers the thesaurus arrow to the second subdivision of its "basic" layer. It opens with the first thematic block "Sound systems", containing the concepts of "classical harmony", "tonality" (including, expanded XX century), "image", "sound system", "gamma", "modality", "seriality", sonoric-phonics principles". The next, second thematic block is "Elements of music. Means of musical language”. The terms "musical sound", "tone", "intonation", "motive", "phrase", "theme", "melody", "harmony" are involved here - with the "see also” note, "polyphony", "texture", “timbre", "register", "meter", "rhythm", "tempo", "loud dynamics", "articulation". The second subdivision of the "basic" part of the thesaurus is completed with the third thematic block of terms called "Musical graphics", where, in addition to music and other signs, indicating the absolute pitch or directionality of melodic movement ("mute", "hooks", "banners", etc.), which includes the whole set of definitions worked out by the art of music: "phrasing league", “fermata", "reprise sign", "pedal", "accolade", dynamic "fork", signs of raising or lowering tone, "fingering" etc. This may include the concepts of "digital bass", "party", "score", "basso continuo", remarks in $A$, in $B$, in $F$, etc. The written, "book" hypostasis of music creates the conditions for its scientific study and awareness. Thus, immersion in the "body" of music leads to the return of the cognitive act to its original position, closing the thesaurus dictionary into another, larger circle.

To complete the idea of the ratio of thematic blocks of the "basic" level of the thesaurus we draw the following scheme (Fig. 2).

\section{The background level of a music thesaurus}

The "background" level of the music thesaurus contains two thematic blocks: "Musical sounding" and "Extra-musical sounding" under the general name "Routine sound environment" (Fig. 3). This is the sphere that supplies music with material for aesthetic processing and emotional awareness, namely the outside world, which is absorbed by individual and collective subjects.

The first block, in turn, is divided into applied and background music. The latter refers to musical sounds that create an acoustic atmosphere of urban topos. 
Similarly, the second block has exits to the urban and natural sound spaces that are reflected in the music arts. It should be noted that all this level of thesaurus corresponds in its essence with K. Schneider's Thesaurus.

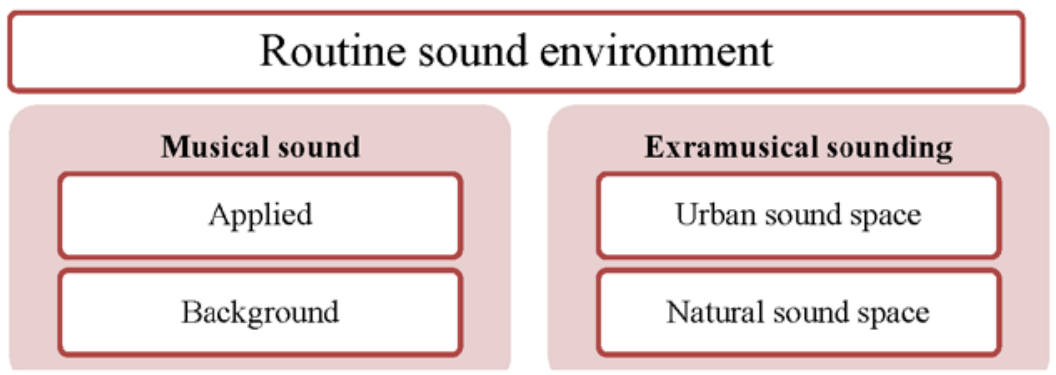

Figure 3. The background level of a music thesaurus

To sum up, let us say that both forms of being of units of knowledge - oral and written - focus on a single subject and have similarities in structure, divided into hierarchically subordinated levels: "superstructural", "basic", and "background". However, the characteristics of the information embedded in each of these forms are not identical since the transition from one state to another is a change of concepts, and the content of each level changes significantly. The "superstructural" part of a set of data stored in the mind means knowledge about music, that is, information related thereto, but is on the verge of conceptual and intuitive-sensory. In the thesaurus, it is corresponds by information that goes beyond musical art to a wide field of culture, testifies to the sources of its cognition, as well as masters the effective forms caused by its content. At the same time, this part of the thesaurus in its oral version also includes knowledge encrypted in the system of terms, located in the "basic" section. Because it is a written document, the vocabulary cannot include directly the auditory impressions encoded in the intonation system of music, as well as the aesthetic and emotional experiences arising from direct contact with musical sound, since the material substance of this art generates such a meaning in translatable into words. That is why the "basic" parts in both forms of the thesaurus do not coincide. If it is created orally by specific musical knowledge (knowledge of the music itself), then in writing it is a terminological apparatus that has historically evolved in 
musical theory and practice. The same applies to the "background" level of the thesaurus, which in one case is related to auditory impressions and reactions occurring directly, and in the other, to their conceptual awareness. In other words, with all the differences in the levels of knowledge of the thesaurus, the information contained in it is arranged in a single sign and cognitive projection because they create a certain information aura around the music and provide insightful ideas about its essence.

The difference between the oral and written forms of the thesaurus implies the purpose of the dictionary as a document and its pragmatic significance. They consist of its special gestalt quality, which allows the user to quickly reach the boundaries of the object being studied, as well as its conceptual field, acting at the same time as a means of primary contact with the subject of knowledge, as well as with a collapsed way of knowing about it. We reiterate that the thesaurus does not claim to be complete information about music or the accuracy of scientific definitions and, moreover, to explain the terms. It only orientates within the existing information space within it, and also sets a certain direction in the search for knowledge. Comprehensive data about music as art, intonation-sound phenomenon, way of comprehending reality, its internal laws and history, the user can obtain in scientific, popular, reference publications, didactic literature, as well as on the Internet, that is, in numerous material forms of music thesaurus. It is equally important to the music consumer that a thesaurus dictionary provides the key to understanding this type of artistic creativity as a particular organism, the penetration of which, for the sake of its knowledge, requires the necessary level of preparation. Thus, the dictionary is able to promote the process of cognition itself. It also helps to find sources of interest, relevant activities and ways to get music education. Finally, the dictionary contributes to the understanding of the multidimensionality of music as a form of art, its heterogeneity in terms of quality, nature of content and functional orientation.

Therefore, the concept of "music thesaurus" is subject to further development. If the first stage of this process involved the disclosure of forms of the thesaurus as a repository of musical knowledge, the focus now is on the structure of this repository, that is, the definition of its constituent units and their relationships. These are, therefore, those divisions of musical knowledge that systematize single representations, impressions, and facts, ensuring the semantic unity of the space of the music thesaurus. 
Both ideal and material forms of music thesaurus retain their relevance for solving research problems, since they have a general methodological character and allow, on the one hand, to enter music into a broad sociocultural context, presenting it as a carrier of intra- and extramusical information, and on the other - to record the fact of structured knowledge (both on different kinds of material carriers, as well as in the consciousness of the collective and the individual). At the same time, the study of the structure of a music thesaurus required the introduction of a different classification, namely, its division into oral and written forms. The first means those units of knowledge that have an ideal and material expression and are fixed in the memory of the collective and the individual; the second is a written projection of the oral, which is embodied through the thesaurus.

\section{CONCLUSIONS}

Music, like any other object of the world of nature and culture, is in the zone of cognitive aspirations of man, as a result of which the system of naming its elements, methods of studying its laws and the very essence itself develop. Thus, there is a "superstructural" knowledge of expanding music, acquiring verbality, formality, and being outlined in various ways of description. In this form, it is readily available for written fixation, the ideal means of which is a thesaurus-dictionary-a documentary display of units of storage of musical knowledge. Therefore, in terms of storage units, the music thesaurus is divided into oral and written.

The question naturally arises as to the forms of knowledge storage. Two forms of music thesaurus are distinguished: the ideal and the material, each of which has several types and modes. In this case, this is in line with the general conception of thesaurus produced by computer science and linguistics, since any knowledge is stored in the collective and individual consciousness, on the one hand, and on various carriers, on the other. And yet, the music thesaurus also manifests its specificity in this regard, applying the special character of embodiment. In an ideal form, it finds its manifestation in fixing the experience of perception and communication through the auditory channel of communication, communication through the music, general ideas about it, "traces" of musical and predetermined impressions, sound images, fragments of music material, and sometimes the whole work in the memory of a professional musician and an educated amateur; material form manifests itself in records, in particular graphic, which has its own historical 
variations, and electronic / mechanical, as well as verbal notes and symbols contained in sheet music, books of various profiles, materials and documents that reveal facts and circumstances creative biography and personal qualities of the composer or performer (including memoirs, diaries, letters), in figurative samples and in canvases of painting. Thus, a system of thematic blocks emerges, the selection of which creates a classification base for compiling a thesaurus. It should be noted that in the aspect of information storage, the oral existence of music as a sound phenomenon, which is perceived by the hearing organs, is included in the material form of the music thesaurus; on the contrary, the "superstructural" part of it implies the knowledge stored in an ideal form, that is, in the minds of the collective and the individual.

\section{SUMMARY}

The article considers information retrieval language, which allows for prompt entry into the semantic parameters of subjects in the humanities. The method of compiling a musical thesaurus and dictionary is given.

\section{REFERENCES}

1. Берестова Т. Ф. Информационное пространство как результат развития инфопроцесса / Т. Ф. Берестова // Вестн. МГУКИ. - 2005. № 3. - С. 106-13.

2. Государственный стандарт Украины. Информация и документация. Многоязычный тезаурус: методика разработки. Изд. офиц. - К.: Госстандарт Украины, 2001. - 76 с.

3. Государственный стандарт Украины. Информация и документация. Одноязычный тезаурус: методика разработки. - Изд. офиц. - К.: Госстандарт Украины, 2001. - 60 с.

4. Жмайло С. В. К вопросу об определении тезауруса / С. В. Жмайло // Науч.-техническая информ. Сер. 1. Орг. и методика информ. работы. -2003. - № 12. - С. 20-25.

5. Жмайло С. В. К разработке современных информационнопоисковых тезаурусов / С. В. Жмайло // Науч.-техническая информ. Cер. 1. Орг. и методика информ. работы. - 2004. - № 1. - С. 23-31.

6. Казанцева Л. П. Коммуникативная направленность музыки с тематическими заимствованиями / Л. П. Казанцева // Музыкальное произведение в системе художественной коммуникации: межвуз. сб. -Красноярск: Изд-во Красноярского университета, 1989. C. $110-128$. 
7. Каптерев А. И. Информация социокультурного пространства / А. И. Каптерев-М. : ФАИР-ПРЕСС, 2004. - 512 с.

8. Шейко В. М. Концептуальні основи освіти як соціокультурного феномену в умовах глобалізації / В. М. Шейко // Інформаційно-культурологічна та мистецька освіта: стан i перспективи: матеріали наук.-практ. конф., 12-13 жовтня 2004 р. I Харківська держ. акад. культури. - Харків, 2004. - С. 121-123.

9. Шейко В. М. Культура. Цивілізація. Глобалізація: (кінець XIX - початок XXI ст.): моногр.: у 2 т. - Т. 1. / В. М. Шейко. Харків: Основа, 2001. -520 с.

10.Шейко В. М. Організація та методика науково-дослідницької діяльності: підруч. для вузів / В. М. Шейко, Н. М. Кушнаренко. Харків: ХДАК, 1998. - 228 с.

11.Шейко В. М. Формування основ культурології в добу цивілізаційної глобалізації: (друга половина XIX - початок XXI ст.): моногр. / В. М. Шейко, Ю. П. Богуцький. -К.: Генеза, 2005. -592 с.

\section{Information about the author:} Kalashnyk M. P., Doctor of Fine Arts, Professor, honoured artist of Ukraine, Head of the Musical and Instrumental Training department H.S. Skovoroda Kharkiv National Pedagogical University 29, Alchevskikh str., Kharkiv, 61002, Ukraine 
DOI https://doi.org/10.36059/978-966-397-215-2/45-63

\section{ORCHESTRAL CONDUCTING: SPECIFIC NATURE OF FORMATION}

\section{Loshkov Yu. I.}

\section{INTRODUCTION}

Conducting as a means of reproducing musical text is a kind of performing art, and the formation of its specific nature is conditioned by the process of understanding the aesthetics of the interconnection of the conductor-interpreter and the musical band. Conducting as a means of directing the process of group performance has long been a functional component of the Kapellmeister's activity. However, the process of thinking about conducting as a kind of musical performing art, its isolation from the system of Kapellmeister's activity and formation of specific professional norms of conductor performance still require further research.

Thus, L. Sidelnikov and H. Makarenko do not differentiate between the concepts of "Kapellmeister's activity" and "conductor performance", functionally identifying them ${ }^{1}$. V. Pluzhnikov ${ }^{2}$ considers the problem of differentiation of the Kapellmeister and conductor activity in his theses within musicological boundaries, which makes it impossible to identify important sociocultural factors of the formation of conductor performance as an artistic phenomenon.

Thus, the objective of the proposed work is to clarify the process of forming a conductor orchestral performance that has evolved from a functional component of the Kapellmeister's activity to a full-fledged variety of musical performing art. This objective has led to the following research tasks:

${ }^{1}$ Сидельников Л. Симфоническое исполнительство. Исторический очерк. Москва, 1991. 286 с.

Макаренко Г. Творчість диригента: Естетико-мистецтвознавчі виміри. Київ, 2005. $328 \mathrm{c}$.

${ }^{2}$ Плужников В. Профессия дирижера и пути ее формирования в западноевропейской театрально-концертной практике XIX века : дисс. ... канд. искусствоведения : 17.00.03. Харьков, 2006. 237 с. 
1) to characterize the specificity of conducting the process of collective performance as part of the Kapellmeister's activity,

2) to determine the factors influencing the formation of conductor performance,

3) to reveal the specificity of comprehension of the conductor orchestral performance as a sphere of musical creativity.

Methodological understanding of the characteristics of conductor performance is carried out on the basis of the application of systemactivity approach, which procedural basis is the analysis of system movement as interdependence, on the one hand, its structure and its forming processes, and on the other, those products of the systemic movement ${ }^{3}$. On these methodological grounds, musical art is distinguished within the framework of artistic creativity in the context of the application of a specific normative system, the basis of which is musical text as an object of representation, musical instruments as a means of reproduction of text, performing technique and means of expression as a way of reproducing text, musical theory as form of creation, systematization, preservation and transmission of texts, aesthetics of performance, based on the relationship "performer audience" (place of performance, behavior on stage, appearance, etc.) ${ }^{4}$. Therefore, the logic of the presentation of the material is based on the consistent elucidation of the characteristic features of the formation of conductor orchestral performance as a specific sphere of musical creativity.

\section{Understanding conducting as a kind of musical performance}

Formation of the Kapellmeister's activity as a form of socio-cultural practice occurred under professional differentiation in musical practice. Kapellmeister art, as a form of professional activity, functioned on the basis of adherence to a certain system of rules. In particular, during the performance of the performing-conducting function, the norm was the means of leadership of collective performance, which in specific conditions were clear to all participants of the process. At the same time, the lack of formulation of other norms for the collective representation of

3 Щедровицкий Георгий Петрович. Избранные труды. Москва, 1995. C. 58-64.

${ }^{4}$ Лошков Ю. Профессиональное музыкальное искусство европейского типа // Мистецтвознавство XX століття. Херсон, 2017. С. 38-39. 
music - the composition of the orchestra, its location, the location of the conductor himself during the performance, the aesthetic principles of reading the musical text, etc. - have led to the variety of means used to guide the process. Only the ordering of these norms made it possible to form a special system of signs - conductor manual technique as a professional language of communication for the participants of the performance process - the leader and the musical band.

The formation of the orchestra, organized according to the principle of group mapping, as a form and a means of reproducing the musical text, took place within the framework of the Kapellmeister's activity. The dynamics of the process of systematic formation of the musical band was provided by the comprehension of the musical text by Kapellmeisters as universal musicians. In this context, conducting has evolved as a system of signs aimed at the optimal transmission of information (the "performance model") for reproduction of text by a musical collective. On the basis of the professional experience of Kapellmeisters, who practically implemented the philosophical understanding of music, theoretical thought was formed as a form of creation, systematization, preservation and transmission of musical texts. The final formation of the systematic components of the Kapellmeister's activity helped to distinguish the conductor's performance as the art of sole guidance by the collective representation of the musical text.

The prerequisites for a new kind of performing arts emerged in the first half of the XIX century in the musical culture of Western Europe. The major impetus was the emergence of musical romanticism, whose leading representatives formed the aesthetic basis of a new performing field orchestral conducting. The central idea of the German romantic aesthetics of the turn of the XVIII and XIX centuries was that art is a way to unite the individual soul with the "soul of the world". For the creators of this concept, identifying the single with the common is only possible in the artistic experience of "essence" (in the primary sense - "divine"). The ideologue of musical romanticism, Robert Schumann (1810-1856), emphasized that for the representatives of this artistic trend, the ultimate goal is to uplift the German spirit through German $\mathrm{art}^{5}$. This situation determined the specificity of the artistic imagery of musical romanticism and actualized the prerogative of the performer as an interpreter of the musical text and mediator between the author and the public.

\footnotetext{
${ }^{5}$ Роберт Шуман. О музыке и музыкантах. Москва, 1975. Т. 1. С. 262.
} 
This ideology served as the foundation for professionalization in music and, in particular, differentiation within the Kapellmeister's activity. Thus, the refinement and complication of musical language on the basis of ideological deepening of the content caused the composers' demand for artistic quality of the performance process in the context of improving the professional skill of both the musical band and the leader of the performance process. These changes led to the emergence of professional musicians-educators, whose goal was the qualitative professional training of performers. At the same time, the desire for selfimprovement led to the gradual focus of musicians on certain varieties of creativity, in particular compositions and directing collective performance, which previously represented a synthetic Kapellmeister art.

On the other hand, the gradual decline in the solvency of the European aristocracy led to the democratization of professional music activity. Musicians have refocused, in the sense of financial support, from court professional activity to general public performance. This situation led to a transformation within the ratio of "performer audience", the basis of which was the actualization for musicians of the problem of popularity in the public. In this regard, muscular virtuosity, musical effects aimed at instant impression, outrage not only on stage but also in life became widespread during the period of musical romanticism.

These conditions played a significant role in the formation of the "German Romantic Conducting School" (defined by D. Rabinovich ${ }^{6}$ ), whose aesthetic foundations were laid by prominent universal musicians, significantly represented by Kapellmeisters. In particular, the creation of the first artistically significant musical romantic works is related to the names of E.T. Hoffmann (1776-1882) and L. Spohr (1784-1859), whose creativity largely took place within the scope of the Kapellmeister's activity.

Hector Berlioz (1803-1869) emphasized that he became a conductor because of his dissatisfaction with the level of performance of his works. He demanded from the band members not high technical virtuosity, but artistic devotion: "The individual must retreat to serve the whole, and the latter, in turn, must obey the will of its leaders" ${ }^{7}$. Here are traces of the aesthetic aspirations of outstanding romantics to

${ }^{6}$ Рабинович Д. Исполнитель и стиль. Избранные статьи. Москва, 1981. Вып. 2. 230 с.

${ }^{7}$ Роберт Шуман. О музыке и музыкантах. Москва, 1975. Т. 1. С. 211. 
optimize the relationship of "musical text - public" in the context of the audience's perception of the author's intention. R. Wagner was one of the first to write abstracts of works performed and to publish them long before performances, which not only attracted the audience but also prepared it for a meaningful listening to music.

Understanding of a conductor by the romanticist composers as the main mediator in bringing the author's idea to the ideal listener has influenced the extension of the boundaries and tasks of manual technology as the norm of interaction of the performer-conductor with the form of reproduction of musical text - orchestra. The name of Karl Maria von Weber (1786-1826) is associated with the introduction of the rehearsal process as a mandatory norm for preparing a piece of music for public performance and for fixing a particular arrangement of the orchestra and conductor during the presentation of music. Richard Wagner (1813-1883) focused on the substantive constituent of interpretation and the means of its implementation in conducting work, and in this connection, he attached great importance to the rehearsal work, actively promoted the introduction of progressive ways of working with the orchestra. Hans von Bülow (1830-1894), as a professional conductor, paid considerable attention to the development of conducting technique, direct rehearsal, as well as the performance of a wide range of works of different eras, styles, and genres, which actively contributed to the enrichment of the conducting normative system. According to his example, the conductors began to increase the number of rehearsals, pay attention to the ensemble, and be more attentive to the reproduction of various nuances by means of manual technique.

Understanding the possibility of conveying by the conductor personal artistic intentions directly during performance led to the need for visual contact with the orchestra. Due to this, from the first half of the XIX century, as a norm of "conductor - orchestra" interaction, the faceto-musical band conducting was extended. In particular, Niccolo Paganini (1782-1840) in the 1830's wrote that already at that time the conductor's place in the European orchestras during the performance was there, where he could "convey his thoughts and wishes to singers and musicians", "make signs with his eyes, and was the center of orchestral musical unity" 8 . R. Wagner, referring to his idol - Gaspar Spontini (1774-1851), cited the words of the Italian about conducting: "My left

${ }^{8}$ Тибальди-Кьеза М. Паганини. Москва, 1981. С. 229. 
eye is the first violin, my right eye is the second violin" ${ }^{9}$. Thus, the need to provide musicians with collective information reflecting the conductor's performance model of the musical work, led to the formation of a universal system of signs based on manual technique.

Understanding the role of the conductor as an interpreter of the musical text actualized the problem of professional training. In the 1860s, R. Wagner started a performing school, educating conductors in direct practical communication while staging his works. Among them are H. von Bülow (premieres of Tristan and Isolde and Nuremberg Meisterzinger in 1865 and 1868 respectively at the Royal Music School of Munich), F. Wülner (premieres of The Rhinegold and Valkyrie in 1869 and 1870 respectively in Munich) and H. Richter (premiere of tetralogy “The Ring of the Nibelung” in Bayreuth in 1876), G. Levy (premiere of Parsifal in Bayreuth in 1882).

Felix Mendelssohn-Bartholdy (1809-1847), who actively contributed to the establishment of Leipzig Conservatory in 1843, focused on the systematic training of conductors. Appreciating Mendelssohn's conductors, R. Wagner emphasized that "... they are characterized by the sophistication of manners... are much subtler in the nature of the new orchestra, which their teacher Mendelssohn make particularly gentle and sensual in sounding..."10. L. Sidelnikov noted that it was in Mendelssohn's activity for the first time that trends of separation of performance from composing were traced, due to the fact that Mendelssohn as conductor promoted, above all, not his own works, but the works of other authors ${ }^{11}$. His name is associated with the formation of "historical" style in the performance, which made the concert stage sound of musical works of previous eras.

Thus, the practical activity of the leading representatives of musical romanticism have crystallized role functions and principles of interaction of the conductor with the musical band. At the same time, the aesthetic foundations of conductive art are defined in the journalistic creativity of romantics. The practical knowledge of Berlioz as a conductor formed the basis of the fundamental work "Grand traité de l'instrumentation et orchestration modernes" (1844), and in 1856 he published his treatise "Le chef d'ochestré et les nouveaux instruments", which is considered an

\footnotetext{
${ }^{9}$ Вагнер Р. Моя жизнь. Москва, 2003. Т. 1. С. 462-463.

${ }^{10}$ Вагнер Р. Избранные работы. Москва, 1978. С. 89.

11 Сидельников Л. Симфоническое исполнительство. Исторический очерк. Москва, 1991. С. 137.
} 
organic part of teaching about instrumentation. However, this treatise is devoted not so much to the problems of practical craft preparation as to the expression of G. Berlioz's beliefs about the aesthetic role of the conductor. The aesthetic judgments of the artist, according to the editor of the Russian translation of the "Great Treatise..." (1972) S. Gorchakov, are the basis of the main and invariable importance of labor ${ }^{12}$.

The active conduct activity of R. Wagner ended several years before he wrote an article "On Conducting" (1869), which played a significant role in understanding the conducting of collective performance as a form of creativity. The artist emphasized the fundamental need to combine creative aspirations and professional skills to bring conducting to the artistic level. It was with regard to the aesthetic significance of $\mathrm{R}$. Wagner's instructions that the outstanding German conductor B. Walter noted that none of the musicians would remain indifferent to their axiomatic significance as an educational factor ${ }^{13}$.

The ideas expressed by F. Liszt in “The Letter of Conducting” (1853) clearly reflect the differences between the highly artistic and artisanal approaches to directing collective performance. The peculiarity of F. Liszt's performance, which was based on conducting periods and musical phrases, contrary to the traditional display of the fate of the beat, provoked vicious attacks by contemporary artisans who used to be guided by the existing sign system as a form of communication between orchestrators and conductors. F. Liszt's manner of conducting, as a natural manifestation in practice of the romantic principle of infinite melody, testifies to the artist's desire for a highly artistic reproduction of a musical masterpiece in live sound. This focus of the process of collective performance conducting led to the use of not the system of signs traditional for conducting but, in the artist's view, of the optimal means of solving creative problems. In the preface to the score of the symphonic poem "Mazepa", expressing his desire to eliminate the "barred play", the artist insisted, first of all, on the conductor's understanding of the musical text, which he should be able to convey to others ${ }^{14}$. This guideline outlines another fundamental aesthetic

12 Берлиоз Г. Большой трактат о современной инструментовке и оркестровке. Москва, 1972. Т. 1-2. С. 7.

13 Вальтер Б. О музыке и музицировании // Исполнительское искусство зарубежных стран. Москва, 1962. Вып. 1. С. 14.

14 Гинзбург Л. Дирижерское исполнительство: Практика. История. Эстетика. Москва, 1975. С. 150-151. 
requirement for the conductor: the need to be able to verbally convey the performance model of the work (quality is not in the aesthetics of solo performance) determines the understanding of music not only on a sensual but also on an intellectual level.

Contrary to the tendency of spreading entertaining genres of music, the romanticists, being engaged in performing activity, actively promoted creativity of the prominent composers of previous times, especially works where the element of feeling was most freely displayed. For this reason, the successful interpretation of L. van Beethoven's works was a criterion for the musician's ability as a conductor. V. Furtwengler wrote that L. van Beethoven embodied in his works completely opposing states of mind, and only the performer was able to convey the idea of his works ${ }^{15}$. Such demand for conductors is conditioned by the sophistication of the imagery of the works of the outstanding romantic musicians. Their scores could not be performed only with a satisfactory ensemble; they needed sophisticated technique and musical insight. The composer-conductor of the Romantic era considered his creative duty to obtain from the musical band a highly artistic embodiment of both personal and other ideas. The aesthetics of the art of conducting was based on the educational principle: the conductor interprets a musical work, adhering to an author's concept, designed so that he can convey it to the performing team and then, in a joint creative impulse, to the public. That is, the conductor, while interpreting a work of art, is engaged in self-education (personal comprehension), professional (practical embodiment of interpretation in work with a musical collective) and general aesthetic education (public performance of the interpreted work).

Consequently, the orchestral conducting as a kind of musical performing arts was formed in the second half of the XIX century in the musical culture of Western Europe on the aesthetic basis of Romanticism, the main characteristic of which is "appeal to the inner, mental world of human"16. Creativity of outstanding representatives of musical romanticism, who embodied the outstanding talents of the thinker, composer and performer, contributed to the understanding of the artistic mission of the conductor, accumulated in the words of R. Wagner: "... To be the transmitter of the artist, the true representative

15 Гинзбург Л. Дирижерское исполнительство: Практика. История. Эстетика. Москва, 1975. С. 433.

${ }^{16}$ Васина-Гроссман В. Романтическая песня XIX века. Москва, 1966. С. 12. 
of the composer-creator is like (conductor - Yu.L.) special duties to maintain the seriousness and purity of the arts in general: the performer is a kind of crossing point for artistic thought, which to some extent only through his mediation becomes real life..."17.

\section{Conducting of the first half of the $X X$ century}

The verge of the XIX and XX centuries became a period of distribution and approval of conducting as a performing art. This is due to the professional work of artists - contemporaries and adherents of R. Wagner and $\mathrm{H}$. von Bülow, whose creative work led to the emergence of a large number of followers - practitioners and theorists, which contributed to the understanding of the role and importance of the German school in the evolution of conducting. L. Ginzburg noted that "If we talk about Wagner reforms in the opera field, then we deal with a real revolution in conducting. The opera has further developed in several directions, and in the performance everything that had to do with the great art on the symphony concert stage, proceeded from the ideas expressed by Wagner. Thanks to him, as well as to his generation of disciples and followers, the progress of the performance that became possible at the turn of the XX century led to the real flowering of world music culture" ${ }^{18}$.

Distinguishing from this generation the so-called "post-Wagner Five" (Hans Richter, Felix Mottl, Gustav Mahler, Arthur Nikisch, and Felix Weingartner), V. Bohdanov-Berezovskyi emphasized that their fate "had the honorable but already easier task of preserving and the further development of national traditions ${ }^{19}$. The above artists unite the time boundaries of their active creativity - the last decades of the XIX - the first decades of the XX century, and the prerogative of historical direction in repertoire politics, since the performing talent of most of them greatly outweighed the composer's, and the aesthetic task of "preserving and further developing national traditions" necessitated a constant selfexpression in the interpretations of monumental musical works. Thus, for more than 20 years (1875-1897), H. Richter (1843-1916) was a conductor of the Vienna Court Opera. His professional career was significantly

\footnotetext{
${ }^{17}$ Вагнер Р. Избранные работы. Москва, 1978. С. 57.

${ }^{18}$ Гинзбург Л. Дирижерское исполнительство: Практика. История. Эстетика. Москва, 1975. С. 143.

19 Богданов-Березовский В. Советский дирижер. Очерк деятельности Е. А. Мравинского. Ленинград, 1956. С. 271.
} 
influenced by R. Wagner, whose protection provided the 25-year-old educated pianist and composer with the post of choir master at the Munich Opera. R. Wagner's attitude to the professional pursuit of H. Richter as a conductor and his adept was to trust the latter to direct the premiere staging of tetralogy in Bayreuth in 1876.

The professional formation of F. Mottl (1856-1911) proceeded in direct communication with R. Wagner. In 1876 he assisted H. Richter in the preparation and conduct of the first Bayreuth Festival, where from 1886 to 1906 he performed Wagnerian operas 69 times. In 1914, the clavicles of R. Wagner's operas made by F. Mottl were posthumously published. Due to the professional work of Ernst von Schuh (1846-1914), whom D. Rabinovich attributed to the artists of H. Richter and F. Mottl's level ${ }^{20}$; R. Wagner's last operas were performed in the Dresden Court Opera.

If the basis of H. Richter and F. Mottl's repertoire were R. Wagner's works and classical heritage, then E. von Schuh is considered to be an excellent interpreter of Italian opera and musical drama. In particular, he staged R. Strauss's operas on the Dresden stage: "Salome" (1905), "Elektra" (1909), "The Knight of the Rose" (1911).

Among the representatives of the "post-Wagner Five" is the figure of the eminent Austrian G. Mahler (1860-1911), who, in the 1880s, was very much like $\mathrm{H}$. von Bülow in his manner as a conductor ${ }^{21}$. Already at the turn of XIX - XX centuries, G. Mahler completely departed from the influence of $\mathrm{H}$. von Bülow's technique. According to the memoirs of the Austrian opera singer Anna von Bar-Mildenburg, there was nothing ostentatious in G. Mahler's technique; conducting was not turned into acting; he did not intend to draw attention to himself, but "sought only to serve and to execute the will. When everything went according to his plan, the orchestra and conductor would have to become invisible so that no one could notice either work or sweat"22.

In relation to metric schemes, G. Mahler followed F. Liszt. Violinist Natalie Bauer-Lechner mentioned that it was impossible to determine how G. Mahler was showing tact during his conducting. The artist could only trace the first, emphasizing the second or third fate of the beat, depending on the content of the music. The artist emphasized that it is

${ }^{20}$ Рабинович Д. Исполнитель и стиль. Избранные статьи. Москва, 1981. Вып. 2. С. 50.

${ }^{21}$ Густав Малер. Письма. Воспоминания. Москва, 1968. С. 296.

${ }^{22}$ Ibid. C. 380. 
necessary to constantly suppress the beat so that it "hid behind the melody and rhythm, as the cloth base of the tapestry along the lines of the drawing" ${ }^{23}$.

Certain characteristic features of G. Mahler's creative credo are due to the combination of the genius of the composer and conductor in his personality. In particular, the artist was jealous of the adequate representation of his works, characterizing their performance, where the preparation took place without the participation of the composer, as meaningless $^{24}$. G. Mahler's dissatisfaction was largely due to the lack of creative commitment of the orchestras in the process of working on the musical text. Thus, in 1883, in a letter to the conductor of the Olomouc Opera House, F. Leroux, the artist wrote: "Often, when I ignite and want to capture, inspire them (orchestral musicians - Yu.L.), I see the astonished faces of these people, how they smile at each other with understanding... The only feeling that I suffer for the sake of my great masters is that, probably, I can still throw at least a spark of fire into the souls of these poor people, tempers my courage" ${ }^{25}$. These words were not only concerned with the orchestras of a particular collective, because 12 years later, G. Mahler expressed with pain: "I do not count on understanding my "colleagues" for a long time. I feel I should seek those who will ever follow me not where the music is being created, etc. My music is an experience, so how those who do not "live" can treat $\mathrm{it}^{26}$.

This is the reason for Mahler's desire for a meticulously accurate reading of the author's text, which his critics characterized as pedantry. But the artist was convinced that this approach alone helps to reveal thoughts and feelings embedded in the music. In this way, he determined his retouches in the instrumentation of the Beethoven's symphonies, seeking to put into service the author's designs all the means of the modern orchestra. This feature of Mahler as a conductor predetermined his careful attitude to rehearsals, which, according to the memories of the Russian conductor $\mathrm{O}$. Khessin, were more interesting than the concert itself: the artist explained the meaning of each musical phrase, made many notes, working out the smallest details ${ }^{27}$.

${ }^{23}$ Густав Малер. Письма. Воспоминания. Москва, 1968. С. 475.

${ }^{24}$ Ibid. C. 227.

${ }^{25}$ Ibid. C. 101.

${ }^{26}$ Ibid. C. 153.

${ }^{27}$ Ibid. C. 445. 
For 20 years G. Mahler headed the opera houses of Budapest (1888-1891), Hamburg (1891-1897), Vienna (1897-1907) and earned the fame of the phenomenon that personified the brilliant director and conductor. The specificity of such activity formed an uncompromising dictatorial attitude in the artist to implement creative ideas in working with a theater company: G. Mahler's demands were fulfilled unquestionably.

G. Mahler's antipode was considered Hungarian Arthur Nikish (1855-1922). In contrast to G. Mahler, A. Nikish, who formed as a musician in the specific conditions of the cultural life of Vienna in the 1860s-70s, was an improviser on the stage. He did not require dictatorial follow-up on specific details of his plan, enabling musicians to be co-authors of interpretation during the performance. Already contemporaries, recognizing A. Nikish as the largest representative of the conductive art of the romantic direction, characterized him as an inspired artist, possessing an external restraint, the exceptional force of influence on the orchestra. After observing the conductor during a concert, P. Tchaikovsky in 1887 wrote that "Mr. Nikish is calm and free from unnecessary movements, cool-headed and at the same time very strict. It seems that he does not conduct but produces some magical passes. He does not try to attract attention, but it is felt that a large orchestra, like an instrument in the hands of a skilled master, fully obeys its leader" 28 . Since 1882, A. Nikish headed the leading opera and symphonic groups of Leipzig, Boston, Budapest, Berlin, and Hamburg; engaged in active touring activity, promoting the works by L. van Beethoven, F. Liszt, R. Wagner, J. Brahms, G. Mahler, M. Reger, A. Bruckner, R. Strauss, R. Schuman, P. Tchaikovsky, and M. Rimsky-Korsakov; since 1902 he trained conductors at Leipzig Conservatory.

F. Weingartner (1863-1942) graduated Leipzig Conservatory as a conductor in 1883, whose extraordinary talent already in the late XIX century made him one of the leading conductors of Germany. F. Weingartner's fame was based primarily on the interpretation of symphonies by L. van Beethoven and other classical composers. Significant place in the work of the conductor took the journalism. In particular, in the book "On Conducting" (1895), the artist formulated the principles of the German Romantic Conducting School, among which was the premise that a qualitative interpretation of the conductor does not improve the work, but can only correspond to its true value.

${ }^{28}$ Сидельников Л. Чайковский-дирижер. Київ, 1991. С. 108. 
For a long time, F. Weingartner published methodical manuals on the problems of conductor interpretation of symphonic works by V.A. Mozart, L. van Beethoven, R. Schumann, and F. Schubert. These guides initiated a certain line of methodological literature in conductor performance aimed at assisting the interpreter in creating a performance model of a musical work. Weingartner's outstanding talent as a publicist in the first decades of the XX century significantly influenced the formation of the main areas of specialized literature in conducting. Thus, in the article "Conductor" (1912), the author first emphasized the need to master conductor manual equipment as one of the main factors for successful management of musical performance and formulated the main professional provisions for the development of conductor technique.

The decisive role in the formation of the conductor belonged to the works by Richard Strauss (1864-1949) and Karl Muck (1859-1940). R. Strauss's conducting career is mostly related to the cultural centers of Germany and Austria, but as a touring artist in Europe and the USA, he has performed with many of the world's leading orchestras of the time. A prominent artist who went from late Romanticism to expressionism and neoclassicism in composer work, Strauss was a prominent representative of the German Romantic School - contemporaries noted a marked external decency in the performance and modesty of movements. A graduate of Leipzig Conservatory, K. Muck was a Kapellmeister since the early 1880s, and since 1886 became the first conductor of the German Opera House in Prague, succeeding H. Mahler; from 1892 to 1912 he was a conductor of the Royal Opera in Berlin and at the same time directed the symphonic concerts of the Royal Chapel. K. Muck's recognition as a leading conductor contributed to his assignment in 1912 as a leader of Boston Symphony Orchestra.

In general, since the late XIX century, the authority of the German Romantic Conducting School led to the invitation of its best representatives to lead musical groups in other countries. Thus, A. Nikish was conductor of Boston Orchestra from 1889 to 1893, and H. Richter collaborated with Manchester Halle Orchestra (1897-1912). G. Mahler in the last years of his life headed New York "Metropolitan Opera", and four years later, the Austrian - Arthur Bodanski (1877-1939) as a conductor began his more-than-20-year cooperation with this theater. We should mention Fritz Rayner (1888-1963), who started his conducting career at the opera houses of Budapest and Dresden, from 1922 headed the leading music groups of the USA (1922-1931 and 1938-1948 respectively, Cincinnati and Pittsburgh Symphony Orchestras; 1949- 
1953 - Metropolitan Opera; and the last 10 years - Chicago Orchestra) and for about 30 years worked at Curtis Institute, teaching future conductors the aesthetic principles of the German Romantic Conducting School.

The second quarter of the XX century brought to the horizon two outstanding conductors-thinkers. Bruno Walter (1878-1962) debuted as a conductor at the end of the XIX century at Cologne Opera House, later moving to Hamburg, where he worked under the supervision of G. Mahler. During 1913-1922 B. Walter directed the Mozart and Wagner festivals in Munich, in 1925 he headed Berlin State Opera, and after 4 years - Leipzig "Gewandhaus". The rise to power of the Nazis forced B. Walter travel to the United States, where the artist conducted in the Metropolitan Opera, performed with the best orchestras. Much of B. Walter's repertoire was preserved in sound recordings.

B. Walter's journalistic activities played a significant role in shaping the directions of methodological literature in conducting. This concerns the work devoted to the personality and creativity of B. Walter's teacher - G. Mahler (1936) and the autobiographical book, "Theme with Variations" (1947). The book has become a remarkable historical essay providing contemporary scholars with information from various fields of culture in the first half of the XX century. The logical continuation of B. Walter's autobiographical book was the work "On Music and Music-making" (1957), where the author expressed his aesthetic and methodical views on the art of conducting. Explaining the title of the book "Theme with Variations" as a complex sequence of experiences, events, and changes in his personal life, the artist emphasized that the main theme - his musical credo - was not fully disclosed. Therefore, the book "About Music and Music-making" was considered by the author as the "final of the autobiography", which continued and supplemented "Theme with Variations" ${ }^{29}$.

Wilhelm Furtwängler (1886-1954), an extraordinary artist, whose aim was to assert the beauty and nobility of classical art, debuted in Munich in 1907. Subsequently working as a musical director of opera houses in Lübeck and Mannheim, conducting the orchestras of Frankfurt, Berlin, Vienna, W. Furtwängler took the leading positions among German conductors. He has toured as an opera and symphonic conductor, notably in the United Kingdom (since 1924) and the United

29 Вальтер Б. О музыке и музицировании // Исполнительское искусство зарубежных стран. Москва, 1962. Вып. 1. С. 17. 
States (since 1925); he headed Leipzig “Gevandhaus” (1922-1928) and Berlin Philharmonic Orchestra. After 1933, as the largest Aryan conductor, he occupied a significant place in the structure of Hitler's regime. With the fall of the Third Reich, he was excommunicated from the management of Berlin Philharmonic Orchestra. Later he conducted and recorded in Salzburg, Milan's La Scala Theater, performing in London, Paris, and Stockholm.

If B. Walter is considered an "extra-class virtuoso" (D. Rabinovich), then V. Furtwängler, although pointing in the publications on the importance of manual technology, did not possess this skill. Experts have characterized his gestures as quirky and awkward, some times out of the musical rhythm. But the musicians under his leadership appeared to be under hypnosis, resulting in extraordinary creative success based on a convincing and logical interpretation of the work. Meanwhile, similar observations apply to most representatives of all generations of the German Romantic Conducting School: the conciseness of the movements of A. Nikisch, F. Weingartner, R. Strauss, G. Knappersburg and others; the tradition of leveling metric schemes, started by F. Liszt and supported by G. Mahler and later by G. von Karayan and others; blurry of the manual technique of A. Nikish, F. Weingartner and others made it possible for art critics to identify the secondary nature of manual technique in understanding perfection of conducting skills as a characteristic feature of the phenomenon ${ }^{30}$.

During the 1930's and 40's, V. Furtwängler published his major nonfiction works. He was the first who discovered a problem in conducting art in the mid-XX century, that D. Rabinovich called "the decline of the old German romantic conducting school”. Noting that the performing style had developed in the past by the composers and pointed to the interpreting performers, constantly controlling them, V. Furtwängler emphasized that the creators of the "new music" as the antidote to the "old", also lost their internal connection with the past. From that time, the artist believed, the burden of the conductor was "unprecedented responsibility - to create a style of individual works that define the works themselves" ${ }^{31}$. Such a task could only be performed by

${ }^{30}$ Рабинович Д. Исполнитель и стиль. Избранные статьи. Москва, 1981. Вып. 2. С. 192.

${ }^{31}$ Гинзбург Л. Дирижерское исполнительство: Практика. История. Эстетика. Москва, 1975. С. 403. 
eminent artists, that is, "ideal conductors", defined by artists of the XIX century.

At the same time there were also changes in the attitude towards conducting as a professional activity. The quantitative growth of professional conductors and their qualitative alignment stimulated the struggle for the audience, which led to changes in the repertoire policy of conductors of that time. The basis of the repertoire of German conductors in the first quarter of the XX century was the works by the German classics, and the criterion of creativity was the inspiring performance of L. van Beethoven's heritage.

However, the desire for popularity made the conductor community find ways to satisfy the public's preferences. First of all, it affected the content of the concert programs, which were increasingly diversified by the exterior of spectacular music works. The focus on the departure from deep philosophical ideas, the replacement of their effectiveness, external multicolourism, "belligerent technicality" noted theorists and critics of the mid-twentieth century. In the publication Beethoven and We, V. Furtwängler, asking himself the question "Why is Beethoven so poorly performed?", answered that the composer, in accordance with his temperament, expressed in the works completely opposite mental states, which must involve a performer to achieve a positive result in interpretation $^{32}$.

\section{CONCLUSIONS}

Thus, the outstanding musicians of the XIX century on the basis of romantic aesthetics in practice and in theory formed the artistic principles of orchestral conducting due to the following factors:

- the specific nature of romanticism as an artistic trend, which feature is the appeal to the inner sensual world of man, led to the identification of the performer (especially the conductor) as an important subject of the creative process, whose role is to adequately convey the author's intention to the public;

- professional activity of K.M. von Weber, F. Mendelssohn, G. Berlioz, R. Wagner, F. Liszt, and H. von Bülow contributed to the understanding of the leadership of collective performance as a creative process, during which the conductor not only controls the reproduction

32 Гинзбург Л. Дирижерское исполнительство: Практика. История. Эстетика. Москва, 1975. С. 433. 
of the model of the musical text created by the artist during the rehearsal with the band, but also creatively adjusts this model based on his psychological state at the time of performance.

The functioning of the "German Romantic Conducting School" within the dominance of its main characteristics is limited in the middle of the XX century, when certain socio-cultural and purely artistic factors led to transformation in the aesthetics of conducting. First, the global upheavals (World War I) that led to the formation of a new musical and creative sphere - avant-gardism, which underpinned the denial of the artistic heritage of the predecessors, not so much in terms of ideology, but rather as to the use of, in their understanding, obsolete representative system of norms. Such changes have led not only to the expansion of the repertoire thinking of conductors, but also to changes in the attitude of the representatives to the process of reproduction of the author's text, which were, first of all, in the shift of the emphasis on the interpretation during the concert performance to its perfect polishing at the rehearsals. This, in turn, led to a focus on improving individual manual technique as a universal (and traditionally understandable in the professional environment) means of informing the performing band regarding the specifics of the interpretative model of the musical text. In this context, the improvement of the manual technique also led to the quantitative growth of conductors of a sufficient professional level, which, in relation to the existing musical groups, led to a competitive struggle for a place at the conductor console, and therefore to the solution of optimization of the interaction between the interpreter and the performing band.

Coming to the fore during the first half of the XX century in the performing arts of the "historical focus", the specificity of which led to the actualization of the problem of competitiveness of the new presenting repertoire, stimulated a gradual reorientation in the interaction between the composer, performer and listener, making the role of the second a prerogative in the process of popularization of the image of the artist.

\section{SUMMARY}

The subject of the study - the process of forming a conductor orchestral performance. Methodological understanding of the characteristics of conductor performance is carried out on the basis of the application of system-activity approach, which procedural basis is the analysis of system movement as interdependence, on the one hand, its structure and its forming processes, and on the other, those products of the systemic movement. The objective of the proposed work is to clarify 
the process of forming a conductor orchestral performance that has evolved from a functional component of the Kapellmeister's activity to a full-fledged variety of musical performing art. The outstanding musicians of the XIX century on the basis of romantic aesthetics in practice and in theory formed the artistic principles of orchestral conducting due to the following factors: 1) the specific nature of romanticism as an artistic trend, which feature is the appeal to the inner sensual world of man, led to the identification of the performer (especially the conductor) as an important subject of the creative process, whose role is to adequately convey the author's intention to the public; 2) professional activity of K. M. von Weber, F. Mendelssohn, G. Berlioz, R. Wagner, F. Liszt, and H. von Bülow contributed to the understanding of the leadership of collective performance as a creative process, during which the conductor not only controls the reproduction of the model of the musical text created by the artist during the rehearsal with the band, but also creatively adjusts this model based on his psychological state at the time of performance. The functioning of the "German Romantic Conducting School" within the dominance of its main characteristics is limited in the middle of the XX century, when certain socio-cultural and purely artistic factors led to transformation in the aesthetics of conducting. Such changes have led not only to the expansion of the repertoire thinking of conductors, but also to changes in the attitude of the representatives to the process of reproduction of the author's text, which were, first of all, in the shift of the emphasis on the interpretation during the concert performance to its perfect polishing at the rehearsals.

\section{REFERENCES}

1. Берлиоз Г. Большой трактат о современной инструментовке и оркестровке. М. : Сов. композитор, 1972. Т. 1-2. 527 с.

2. Богданов-Березовский В. Советский дирижер. Очерк деятельности Е. А. Мравинского. Л. : Музгиз, 1956. 283 с.

3. Вагнер Р. Избранные работы. М. : Музыка, 1978. 695 с.

4. Вагнер Р. Моя жизнь: в 2-х т. Т. 1. М. : Астрель, 2003. 558 с.

5. Вальтер Б. О музыке и музицировании // Исполнительское искусство зарубежных стран. М. : Гос.муз.изд-во, 1962. Вып. 1. C. 3-118.

6. Васина-Гроссман В. Романтическая песня XIX века. М. : Музыка, 1966. 405 с.

7. Гинзбург Л. Дирижерское исполнительство: Практика. История. Эстетика. М. : Музыка, 1975. 629 с. 
8. Густав Малер. Письма. Воспоминания. М. : Музыка, 1968. 607 с.

9. Лошков Ю. Профессиональное музыкальное искусство европейского типа // Мистецтвознавство XX століття. Херсон, 2017. C. 13-48.

10. Макаренко Г. Творчість диригента: Естетико-мистецтвознавчі виміри. Київ : «Факт», 2005. 328 с.

11. Плужников В. Профессия дирижера и пути ее формирования в западноевропейской театрально-концертной практике XIX века : дисс. ... канд. искусствоведения : 17.00.03. Харьков, 2006. 237 с.

12. Рабинович Д. Исполнитель и стиль. Избранные статьи. Вып. 2. М. : Сов. композитор, 1981. 230 с.

13. Роберт Шуман. О музыке и музыкантах. Т. 1. М. : Музыка, $1975.407 \mathrm{c.}$

14.Сидельников Л. Симфоническое исполнительство. Исторический очерк. М. : Сов. композитор, 1991. 286 с.

15.Сидельников Л. Чайковский-дирижер. К. : Муз. Україна, $1991.217 \mathrm{c.}$

16. Тибальди-Кьеза М. Паганини. М. : Молодая гвардия, 1981. $303 \mathrm{c}$.

17.Щедровицкий Г. П. Избранные труды. М.: Шк. Культ. Полит., 1995.800 с.

Information about the author: Loshkov Yu. I., Doctor of Fine Arts, Professor at the Department of Folk Instruments, Vice-Rector, Kharkiv State Academy of Culture 4, Bursatski Uzviz, Kharkiv, 61057, Ukraine 
DOI https://doi.org/10.36059/978-966-397-215-2/64-83

\section{PLACE OF THE JEWISH THEATER \\ ON THE THEATER MAP OF UKRAINE AND ODESSA \\ (REVIEW AND ANALYSIS OF THE ARCHIVE MATERIALS \\ OF THE ODESSA PRESS)}

\section{Ovcharenko T. S.}

\section{INTRODUCTION}

The Jewish Theater has gone through a difficult and striking path of attitude and affirmation. From the very beginning, he identified himself as national, revealing his identity in forms of existence (badhani singers, Broadzingers, mobile and stationary theaters), in genres of dramatic works (liturgical drama, mysteries, purimspiels, musical comedies, historical operettas, historical operettas), location (Middle East, Europe, Galicia, Romania, Poland, Ukraine). Despite years of being banned from playing Yiddish, being banned from living in big cities, the Jewish theater has proven to be resilient and the Jewish nation is able to adapt in difficult circumstances.The formation of Jewish theater has evolved (birth, formation, decline, rebirth), and this path has been associated with changes in socio-economic, historical and political events in society. It can be noted that the evolution of Jewish theater was continuous, and the developed traditions of theatrical art were passed on from generation to generation, from director to director. Unfortunately, we must admit that Jewish theater art was deprived of such iconic personalities as K.Stanislavsky in Russian, and L.Kurbas in Ukrainian theater. Therefore, in our opinion, it is legitimate to speak not about the traditions of a certain Jewish director, but about the peculiarities of a theatrical formation.

The mystery is not the fact that Ukrainian culture is often compared to Jewish culture.This concerns both the historical stages (the banning of language, resettlement), and the development of theatrical culture (closing down theaters, destroying theatrical figures). There are known facts when the actors and directors of Jewish theaters are compared to the actors and directors of Ukrainian theaters. There has always been applause from the Jewish theater. For example, Esther Kaminskaya, who was compared to M. Ermolova, E.Duse and Maria Zankovetska. Goldfaden himself was called the Jewish «Mark Kropyvnytskyi», and B. Stupka is considered «the main Jew of Ukraine». This gives reason to particularly study the genesis of the existence of Jewish theater in Ukraine, in particular in Odessa. 


\section{Analysis of publications on the topic of the study}

For this purpose, we have analyzed a number of archival materials that contain the overwhelming majority of reviews of relevant performances, as well as information about the common life of Jews in the area. For a complete analysis of the current state of the problem of the study of the evolution of Jewish theater, we have analyzed the sources that we have divided into such groups (memoir literature; literature on the theory of theatrical art; publications in the press and archival materials; fiction; reference literature; academic literature; historical sources; sources) subjects; literature of psychological direction).The analysis of archival documents, research, memoirs, fiction, historical literature, allowed us to consider the theatrical art of Jews in the context of world culture and proved that the «Jewish issue» was always considered one-sided, not deep, subjective and therefore needs further study.

One of the critics of the Jewish theater Chaim Flexer (Akim Volynsky) believed that: «...Jews are naturally theater-like. All of them - conversation, intonation, gesture, movement, plastic, all figure and posture are expressive and must exist on stage» ${ }^{1}$. He regarded the gesture of the Jews as a peculiar language - «real, lively, sharp, sharp, and the Hebrew language - «a fragment of opera from life, «which «turns into a real aria in the synagogue and is the second nature of the Jew»; he noted that the course of the Jews, both in life and on stage, was «clear and solemn». The clothing of the Jews retains the characteristic features of the whole nation, since the Jews «always remain themselves», bearers of what they live». ${ }^{1}$

The most valuable in the Jewish actor is his «temperament, his quick excitability and vulnerability, his emotionality, which is a component of strength and often interferes with the expectation of artistic drawing» $^{2}$. Other researchers also note the emotionality and theatricality of Jews: M. Beregovsky, V. Levitina, M. Loev, J. Roth. In their opinion, «Lets», «clown», «Jester», - is a characteristic feature of almost every Jew from birth.

The first mention of Jewish theatrical performances in Ukraine dates back to the sixties of the nineteenth century, when Gerl Broder

${ }^{1}$ Волынский А. Еврейский театр. Статья 1. Ипокрит // «Жизнь искусства». Л., 1925. № 27 (901). 2-4 с.

2 Волынский А. Еврейский театр. Статья 2. Походный ковчег // «Жизнь искусства». Пг., 1923. № 28. 2-4 с. 
(Margolin) created the first troupe of professional Yiddish singers in the town of Brody.The singers were called «Broadensingers», and they performed in the taverns, food outlets, outdoor summer venues, which greatly expanded the number of viewers. The Brodengzingers were a new type of Jewish folk actor both in terms of the performance technique and the nature of the repertoire. The origins of the art of «Brodensingers» originate in folk shows related to religious rituals and biblical subjects, but, unlike ritual shows dedicated to religious dates or events, the performances of «Brodensingers» were systematic and regular, accompanied by parody, accompanied by improvisation. Basically, the actors played songs, dramatized them, and used makeup and dressing. Very soon Jewish troupes of professional singers-actors appeared in Podillya, Volyn, and in other cities of Ukraine.

The first memories of the creation of a large number of national amateur troupes in the city, which gave performances in different languages, including Hebrew and Yiddish, date back to 1817. There is very little documentary evidence on this page of Jewish theater art, or they are purely informational. E. Binevich noted that the theatrical performances of that time were religious in nature, were devoted to religious holidays, kept folk elements of the Purimshpil, national traditions of parody and improvisation. Given the above, we believe that the emergence of a national Jewish theater in Odessa should be attributed to the first half of the nineteenth century, supporting the opinion of $\mathrm{V}$. Karp and O. Karp, not to 1876, which is the official date of foundation of the Jewish theater.

This fact comes from the analysis of the genesis of Jewish theater art in Western Europe, where stable Jewish theater companies emerged in the eighteenth century, from the analysis of the level of economic and social status of Jews in Odessa, and finally from the analysis of the psychological and national peculiarities of the representatives of this people, and also loyal to them representatives of city government. In this opinion, we are also encouraged by the analysis of the influence of Jewish culture on the peculiarities of the character of the inhabitants of Odesa, language, humor, the tendency of the inhabitants of Odesa to theatrical events, games, improvisation, which made it possible for a whole galaxy of researchers and writers to note the dissimilarity of the inhabitants of Odessa to other residents. 


\section{Formation and self-determination of Jewish theatrical art}

Second half of the nineteenth century, and the beginning of the twentieth century, especially the period 1878-1883 became an important stage in the establishment of the Jewish National Theater. At that time, theatrical life in the city was raging. In 1871, the first National Theater in the Russian Empire was opened at the expense of the Markov counts. In 1912 the summer theater began to operate at the Seventh Station of G. Fontana, in which the Russian troupe under the direction of A. Sergeyev performs. In 1893, a national audience or a national reading audience was opened in Moldavanka to educate the population. «It was a one-story room with a wide and long hall of 1,000 seats, a stage and a lobby, a bookstore, workshops and artistic rooms. Thirty-four dramatic, fifteen literary and musical performances and eleven musical evenings were held here between 1894 and 1895. Another National Audience is working at Slobodka. It seems that Moldavanka seeks to compete with the aristocratic city center in the development of theater arts. In 1899, another theater appeared at the corner of Preobrazhenskaya and Staroyaznichny streets - the Bocharov Theater, better known as the Sobriety Theater, because it was located in the premises of the Society for the Care of Folk Sobriety. Professional troupes of Ukrainian and Jewish actors play in the theater. In 1902, another 1,500-seat theater opens in Moldavanka - Brunstein Drama Theater. The auditorium housed one and a half thousand spectators and had three tiers. In the lobby of the theater exhibitions of artists were constantly held. In 1903 the Sibiryakov Theater was opened (now it is the Ukrainian Theater named after V. Vasylko). In the same year the German club «Harmony» and a small theater in Arcadia under the name «Manchuria» are opened ${ }^{3}$. These theaters did not have state support, permanent premises, and therefore permanent troupes, repertoire, directors, they quickly emerged and suddenly disappeared from the life of the inhabitants of Odessa. Until 1915, only Bolgarova Theater with a Jewish troupe existed from the above mentioned theaters ${ }^{3}$.

Against the background of such theatrical diversity, associated with the growing national and cultural identity of the peoples living in the city, there has been a formation of professional Jewish theater since 1876, theater began to exist. The Odessa press, which also ranked third in the Russian Empire by number of publications, was very interested in

\footnotetext{
${ }^{3}$ Голота В. В. Театральная Одесса. К.: Мыстэцтво, 1990. 245 с.
} 
the vicissitudes of the Jewish theater, but in most publications there is no deep analysis, it is only about news reports: what, when, where a particular troupe played. Often, Jewish troupes are associated with the name of the theater venue where they perform, and many correspondences do not have an author. The insufficiency of the actual material or its substandard quality hinder the full analysis of the formation of Jewish theater in the city in the first years of its existence.

\section{"Odessa period" of Jewish theater}

The first Jewish troupe to appear in Odessa was a theatrical troupe A. Goldfaden, who was touring in Romania at the time, and at the beginning of 1879 received an invitation from her supporters from Odessa. A. Fiszon describes this fact: «Grodner proposes to go to Odessa. Srulik hired a large hall, it is located on Rishelevskaya Street. It is impossible to convey what happened in Odessa. They played not only on Saturdays, but every day. People were spending the night at the ticket offices to get a ticket for at least the fifth day». However, the press in Odessa does not very much approve of A. Goldfaden's performances. So, the reviewer of the «Odessa Bulletin» M. Halperin after attending the performance of «Witchcraft» («Di Kishefmahern»), writes: «The best forces of the troupe take part in this play, but, nevertheless, the play goes sluggish, and there is no way to listen to her, the orchestra is weak and leaves much to be desired. It is worth mentioning only the chief choirmaster of Mr. Hirsfeldfeld (grandfather of I. Dunaevsky), who has done a great deal since the day he joined the troupe of A. Goldfaden. «However, the average audience did not agree with the criticism - in the theater there were sell-outs at almost every performance. The newspaper «Odessa City Council» (January 1880) notes that when the Goldfaden Theater visited the great tragedian Tomazo Salvini, who carefully followed the content of the play, and she was amazed by its originality, he spoke about Jewish theater «This evening they gave «Witchcraft» one of the favorite Jewish plays produced by Goldfaden. The theater was, as usual, almost full, and there was no shortage of applause. It is strange to see how the audience who applauded yesterday for the salvation of Salvini - Othello or Hamlet - is admired today. «Witchcraft», which, moreover, is performed by homegrown celebrities» ${ }^{4}$.

${ }^{4}$ «Глядач». 1922 р. № 6. -8 с.; № 8. - 9 с.; № 9. -8 с.; № $10 .-7$ с. 
In the same 1880 performances of A.'s troupe Goldfaden were banned. One of the Odessa newspapers wrote in August 1880: «Readers already know that a few months later, in Odessa, a troupe of Jewish actors playing the slang play of A. Goldfaden's works, under the direction of the same A. Goldfaden, who calls himself a famous poet, opened performances in the hall of artisans, and then took shelter in the Mariinsky Theater. But it turned out that the plays performed by the troupe were not viewed at all by dramatic censorship.The General Directorate of Press asked the local authorities whether Jewish performances were allowed at all. The result of the request was the termination of performances» ${ }^{5}$.

Summing up the Odessa period of the Goldfaden Theater, the Jewish magazine «Dawn» noted: «The performances attracted a lot of Jewish, and even even non-Jewish, audiences. This fact alone shows that, despite the aversion many people have felt to the Jewish troupe, this troupe, or rather, some slang plays, satisfy the tastes of a large portion of the Jewish public. Considering that the mass of the Jewish population considers attending this theater one of the best pleasures, it suffices that the beggars accumulate money during the week to buy tickets. Goldfaden will be followed by other writers; the ground is laid and the building quickly rises» ${ }^{6}$.

The magazine's correspondent was right. Under the influence of the Goldfaden Theater, Jewish theaters began to be created in the city. At the end of the seventies of the X1X century. many of them, the most famous among them were the corpses of Z. Mogulesco, R. Friedman, I. Grodner, J. Spivakovsky, M. and A. Fiszonov. Odessa becomes a city of Jewish theater art. In 1878 - 1883 the Jewish theater was established in Odessa. With great success at the Mariinsky Theater are the performances of the troupe of Sigmund (Zeliga) Mogulesco: «On Thursday, March 27, the first performance of the invited Jewish troupe was held at the Mariinsky Theater. The comedy «Obsessed by the devil» is presented. Despite the length of the play and the intolerance of the individual types, it was a success due to its careful staging and good execution.The theater was full, and, judging by the first performance, one could foresee a success for the new Jewish troupe, under the direction of comedian Mogulesco» ${ }^{7}$.

\footnotetext{
${ }^{5}$ «Відомості Одеського градоначальства». 1880 р. 31 січня до 31 грудня. 3 с.

${ }^{6}$ Гальперин М. «Рассвет». СПб.1880., № 5. 168-171 с.

${ }^{7}$ «Відомості Одеського градоначальства». 1879 р. № 50. 251.2 с.
} 
After Mogulesco's departure from Odessa, I. Lerner becomes the entreprener of a new Jewish drama troupe still touring in London. St. Petersburg magazine «Souffler» wrote about this: "At the stage of the Odessa Mariinsky Theater now gives its ideas of a troupe of Jewish artists, which was under the direction of I. Lerner and directed by Z. Mogulesco. The repertoire is quite wide, most important of the songs: «Love of Jerusalem», «Obsessed by the devil», «The Rainy Daughter», «Polish Mantis» ${ }^{8}$. I. Lerner dreamed of elevating the Jewish theater to the height of the European one, using a «serious» repertoire, highlighting pressing issues, attracting talented actors from other corpses. For the first time, a classic play by Uriel Acosta's European repertoire appeared on the stage of his theater. This performance amazed viewers and critics alike: «We are honest to say that we were biased at the performance of the Jewish troupe Uriel Acosta. In our understanding, it seemed absurd to choose a Jewish troupe of serious and classical works. The role of Acosta overseas is taken by first-rate actors. Indeed, our assumptions have been misled G. Sheingold skillfully fulfilled the role of Acosta» ${ }^{9}$.

New Jewish acting groups are born in Odessa, which have their audience, their repertoire, their directors. Odessa constantly replenishes professional theaters with its fans. Contemporaries noted that if the Jewish theater did not have this «Odessa» period from 1876 to 1883, it would not have been possible to revive after the tsarist order banning Yiddish performances in the Russian Empire in 1883. For fifteen years in Odessa, Jewish troupes did not speak their native language because they were allowed to play only German in the government's order.These times are not the best period for Jewish theater to preserve the folk traditions, the manner of the play, to convey to the viewer Jewish dramaturgy. The corpses move from city to city, rent the premises under the «German Theater», and play the repertoire of Jewish dramatists in Yiddish, using its similarity to the German language. An important role is played by entrepreners, who not only rented the premises, setting flower prices, but also chose a repertoire, actors to perform roles, agreed with the city or city authorities about touring, and discussed what language they would play. The famous entrepreneurs of the Jewish corpses of that time were S. Adler, I. Berman, M. Weisfeld, N. Eidelman, A. Kaminsky, A. Kompaniets, S. Lobel, D. Sabsai, J. Spivakovsky, A. Fiszon.

\footnotetext{
${ }^{8}$ «Відомості Одеського градоначальства». 1879 р. № 50.251 .2 с.

${ }^{9}$ Ibid.
} 
This fact is described in his memoirs about Jewish actors by I. Fayl: «At that time Jewish performances were banned and organized in a semilegal manner, thanks to bribes given to the police» ${ }^{10}$. The same fact is described by another actor, Boruch Chemerynsky: «Persecuted for their ardent desire to play in their mother tongue, the Jewish actors followed the lines of least resistance. Leaving the big city where a number of Cerberians, headed by a sergeant, bailiffs, stood in their path, the actors scattered throughout the small towns. Here, gathering a few lovers, with the help of «some friends», for a small bribe, the bailiff and the clerk floated to the nearest village, tempted the guards with an arbitrary binge, and by the time the regular denunciation had reached the clerk, the performance had already been played, and the same operation was already underway, in the another other town with other superiors» ${ }^{11}$.

In 1898, after a 15-year break, the first Jewish troupe came to Odessa was the troupe of A. Kaminsky and I. Berman, who left the city after some time because the actors were not allowed to play Yiddish. But almost simultaneously with them there is a troupe of Y. Spivakovsky, who calmly showed all planned performances to the inhabitants of Odessa. S. Lobel's next troupe is again censured by the local authorities and has to leave the city, but in two years in Odessa the troupe of M. Weisfeld, which lasted until 1905, when the united troupe of A. Kaminsky and D. Sabsay returned to Odessa. It can be assumed that such unequal treatment of Jewish theater companies was caused not only by the political situation in the country at that time, but also by problems of the national Jewish theater, the main ones being the lack of qualification of the actors and the lack of quality repertoire consisting mainly of comedies, melodramas and historical operettas of A. Goldfaden, I. Latiner, N. Shaykevich, J. Gordin, which became a cause for concern of the Jewish intelligentsia. That is why the prominent Jewish playwright Sholom Aleichem in 1905 signed an agreement with the touring troupe of A. Spivakovsky and S. Adler to establish a professional Jewish art theater in Odessa. Under this agreement he becomes the artistic director of the theater and undertakes to provide the theater with a repertoire. However, these plans were not destined to come to fruition as the pogroms began in Odessa.

${ }^{10}$ Файль И. Жизнь еврейского актера.М.: Всероссийское театральное общество, 1938.98 с.

${ }^{11}$ Ibid. 
Thus, from 1898 to 1905, there were many Jewish theater groups in Odessa who performed separate troupes or united, staged performances in full sold-out, or disappeared after the first screening. Almost all the Odessa editions of that time paid attention to Jewish theatrical performances. The problems of the national Jewish theater are addressed not only by newspaper reviewers but also by authoritative critics and writers, such as Sh. Asha, I. Pepper. They believe that, in keeping with the national orientation, it is necessary to create a repertoire of theater that would consist of highly artistic dramatic samples of Jewish literature. And in 1906 A. Kaminsky's troupe showed in Yiddish (translated) the plays by M. Gorky «At the bottom», by F. Schiller «Robbers», and the play by the Jewish playwright J. Gordin, who began writing for the Jewish theater as early as the eighties of the nineteenth century, but its melodies were hardly used by Jewish entrepre- neurs and directors.

In 1908, a stationary Jewish theater began operating in Odessa, founded by the renowned playwright P. Hirshbein.The latest ideas of director, entreprener, playwright and actor P. Hirshbein was not always understood by the mass audience, condemned by the Jewish intelligentsia because of the low professional level of the actors, so the theater only worked for two years. The insufficiency of the modern theatrical repertoire made the directors of both Ukrainian and Jewish theaters turn to the plays of A. Goldfaden, J. Gordin, Sh. Ash, A. Shomer and other playwrights who used folk and biblical motifs. Compared to the dramatic works of such well-known playwrights, the plays by J. Gordin and P. Hirshbein were more diverse, showing bright characters and different roles. The dramatic works of these well-known Jewish playwrights were also widely used in the Ukrainian theater of M. Sadowski. It was the first time that the play by the Russian playwright E. Chirikov «The Jews» was translated into Ukrainian, where Leah Zankovetsk played the role of Leia. Unfortunately, the play was banned in 1907 by the local authorities, and it came to light later - in the production of prominent Ukrainian theatrical figures - L. Kurbas and G. Yuri.

In $1908 \mathrm{~K}$. Mardzhanov showed the play of P. Hirshbein's play «On the Other Side of the River», and during this time the Jewish troupe, I. Spivakovsky, decided to show the play «Paval» («Di Newayle») in the city. It premiered on November 23, 1908. Qualified actors were employed in it: D. Fachler, V. Silberberg, E. Mendele-Krause, B. Dalskaya, M. Schwartz. Both plays were a great success.Theatrical news columnist D. Goldstein summed it up: «..two Hirshbein plays were staged. Both the first and the second are definitely valuable contributions 
to Jewish theater. The impression was very pleasant. People have been seen to be serious and affectionate about their commitments.Everything that the rich scene of the Harmony Theater could do was done. We hope that the Jewish intelligentsia will meet and assist the artists» ${ }^{12}$. This may have prompted P. Hirshbein to create his own theater. He invited actors already known in Odessa from the troupe of Y. Spivakovsky: V. Zilberberg, B. Dalsk, J. Ben-Ami, as well as actors beginning the artistic career who graduated from the Odessa drama school: L. Rogov, I. Verite, S. Estrin, Suvorin and others.

On January 26, 1909, P. Hirshbein's Literary and Art Theater opened with his play Engagement. An unknown reviewer of the Odessa News wrote: «Today is a holiday on the street for fans of Jewish theater» ${ }^{13}$. On February 28, the premiere of «With the Wave» («David») was played by $\mathrm{S}$. Ash. «This beautiful play has caused a violent hobby of the overcrowded theater with the passion of the language, the depth of the subject. This is a play of subtle moods, quiet inner longing, unclear searches and, at the same time, a play of everyday life, "wrote an unknown columnist of the Odessa News». On April 1, the troupe showed the premiere of another play by Hirshbein's «Joel» with I. Believe in the lead role, which according to the press reports «...conveyed to the audience with all the talent of the intelligent and intelligent actor, movement, language and feelings of the main character», and his talented partner Noemi «...enhanced his performance with the impression left by the performance» ${ }^{14}$ Along with P. Hirshbein's plays, two premieres were shown to the need of viewers: D. Rosenblitt's «Women's Hearts» and B. Schreiberg's «Unhappy», which the audience and reviewers met coolly. One of them, referring to «Women's Hearts», wrote that «on the stage, which is to replace the old Jewish theater and show a new one, this play cannot take place».The play Unlucky spoke of the tragedy of mixed marriages, and the critic, though acknowledging the «undoubted truth of life», but noted that «the truth of life can speak from the stage scenery in clear, convincing language only when it has turned into the artist's soul, vivid images», and the play by Schreiberg, «not inspired by the breath of

12 Гольдштейн Д. Еврейская труппа П. Гиршбейна. Театральные вести. № $1 /$ 31 января / 1909 г. 2 с.

13 Перец Гиршбейн. «Обручение» Одесские новости, 1909. 5 с.

14 Ibid. 
a real creator - the artist creates an impression not holistic, but sometimes confusing» ${ }^{15}$.

The new season of 1909-1910, the theater began on November 10 with the play «Wandering».Then there were the «Jankel Koval» and the «Avreil Schuster» - melodramas in which «.. Jewish poverty, which has established its residence within the limits of settlement, looks from the stage with its hungry, terrible eyes», S. Steinberg wrote. "The performance of the play is wonderful. G. Ben-Ami attracted the attention of the whole public» ${ }^{16}$.

December 16 saw the premiere of Isaac Sheftel by D. Pinsky. «According to the performance, this performance is one of the best of the season», the Odessa News reviewer said. New premieres are being prepared: «In the City» by S. Yushkevich, «White Bone» by Sh. Ash. Suddenly. «the performances of the Jewish troupe of Hirshbein at the Harmony Theater were suspended by order of the local administration» ${ }^{17}$. Two days later, the performances were allowed to show, but without the participation of the theater director P. Hirshbein. «There was neither explanation nor details. Now the troupe has become known as the «Jewish Dramatic Theater Society of Artists», and J. BenAmi has assumed the role of director. On January 1, 1910, the troupe showed the White Bone. S. Basmanov (Ber), a well-known entrepreneur in the twenties, and V. Schwartzer, who later became a leading actor of the Odessa State, made his debut in this performance. Another premiere of «God of Revenge» by Sh. Ash took place on January 10. Then came the benefits: the benefit of W. Silberberg, whose game was well liked by critics; Beneficiary J. Ben-Ami, who in the play «Satan» by J. Gordin «received great success in the public»; Benefice Noemi, whose play has been criticized for "vividly staging" images of an old Jewish mother and a blind old woman. On February 20, Odessa said goodbye to the theater going on tour. Satan and the White Bone were shown. "The hall was full, It seemed that all the Jewish intelligentsia were in a hurry to express their sympathies to the troupe, apologizing and apologizing for the indifference that manifested itself in relation to Jewish art theater. The game of artists this evening was so good that many will still have a

15 Биневич Е. Гиршбейн П.: Рождение и гибель его театра. «Народ мой». № 23 (315) от 15.12.2003. 7 c.

16 Ibid.

17 Гольдштейн Д. Еврейская труппа П. Гиршбейна. Театральные вести. № $1 /$ 31 января / 1909 г. 2 с. 
good memory of this evening and the regret that the troupe has left the city. It was a beautifully organized troupe with artists who had high expectations, who were waiting for the renovation and revival of the Jewish theater» ${ }^{18}$. The touring of P. Hirshbein's troupe in Belarus and Lithuania was met with coolness by the Jewish public, and only in Warsaw did they become the "event of the day»: "There was some special love and appreciation for the troupe for her arrival, even without regard to the game. The audience, without getting tired, summoned Hirshbein as if emphasizing that she was aware and aware of what a heavy cross this person was carrying so selflessly. And the audience was not just Jewish-theatrical, but quite different: students, technicians, high school students and realists; many students and high school students; but, all in one way or another involved in Jewish art - some artists, sculptors, many writers, musicians - in short, the color of the local national intelligentsia. There were many workers from the more conscious and intelligent. Only the Polish-Jewish intelligentsia, who was hostile to any endeavor in the field of national culture, was amazed by its absence» ${ }^{19}$.

Having received neither material nor moral support from the Jewish intelligentsia, P. Hirshbein disbanded the troupe in July 1910. «The first Jewish art theater died», A. Ardov wrote. - The agony lasted a long time. The agony was unbearable. Under such conditions, only martyrsintellectuals could engage in artistic work» ${ }^{20}$. We did not find a new theater of rich patrons, our own, educated on the best theater models of the public, experienced financial managers.The Hirshbein Theater was ahead of its time and was therefore not always perceived by the audience. Subsequently P. Hirshbein and several actors of his theater emigrated to America (1911). His plays were staged by Jewish theaters in different countries. The new theater wanted the theatrical performances to be one-of-a-kind and thought-out, free from the improvisations of the actors, who had to have a high stage culture, discipline, and clearly follow the directors' text and instructions. The acting skills of the Jewish theater from that time included the ability to show real characters, to convey the psychological state of heroes.

It should be noted that together with the National Theater of the New Direction in Odessa, which existed for only two seasons, remained a

18 Биневич Е. Гиршбейн П.: Рождение и гибель его театра. «Народ мой». № 23 (315) от 15.12.2003. 7 c.

${ }^{19}$ Ibid.

${ }^{20}$ Ibid. 
popular Jewish operetta, whose repertoire was supplemented by original pieces by Jewish composers or the best models of European operetta. Among the stars of the operetta were noted N. Neroslavskaya, J. Zailbert, K. Jung.

In one of the Odessa editions of 1911 we found information about the stay of the Jewish troupe M. Fiszon in Odessa: «Our Odessa is happier than other cities. Sometimes it seems that it is not very safe on the streets of the city, and yet the theaters are not empty. The new theater is not easy to live with. In recent times, Fiszon's corpse, nestled in its walls, does not work worse than in other years.The explanation is simple. Only Jews, most of whom make up the Moldovanka contingent and generally distant from the city center, are visiting the shows, and they do not dare to go out in the evening because of the often recurring "troubles" on the streets. It is nice to note that in the repertoire of the Jewish theater, apart from the melodramas, there are songs of the last movement. There are many good forces in the troupe ${ }^{21}$. About the troupe of M. Fiszon and D. Sabsay are written in other Odessa editions. For example, Theatrical Review applauds Ms. Zaslavskaya's benefit. Sholem Aleichem's play «God of Revenge» and two paintings from A. Fischon's play «Ioiklik and Zeylikl» were staged at the benefit.The author writes that the benefit was worthy. Noting the talent of Ms. Zaslavskaya, who acted as the girl of Manka, the author notes that "other actors were only her background and the choir was indistinct» ${ }^{22}$. After a while the benefit of A. Fischon and the actress of the troupe E. Braginsky took place.The play «Three Weddings in One Evening» was successfully passed and was intended for Jewish teachers. In the same year, viewers saw A. Goldfaden's operetta in A. Fischon's treatment of «Jacob and His Sons (The Sale of Joseph)» and a play for Jewish children with hearing impaired «Der Griner Actor» with songs and dances, which were noted in Odessa the press.

Meanwhile, the formation of Jewish theater art is difficult, as truthfully told in an interview with the scene and life correspondent of Odessa Jewish troupe M. Fiszon. Asked if there was a future for Jewish theater, he said that there was no dramatic material, a low level of spectator culture that needed only «...humor and fun», an insufficient professional level of actors, and a lack of a single cast: «...Our aim was to show to whom:

21 «Відомості Одеського градоначальства». 1881 р. № 2, 3, 4, 7 / від 2 січня до 10 січня. 3 с.

22 «Театр». 1940 р. № 3 - 157 с.; № 5 - 183 с.; № 7 - 160 с.; № 12 - 46-49 с. 
«... Jewels of pearls of dramatic art, create a repertoire, but there is no such thing! There are almost no authors. I firmly believe that both the authors and the plays will be there, and in eight to ten years the Jewish theater will be in full reverence and prosperity!» ${ }^{23}$.

Later, appraising the pre-revolutionary Jewish theater, prominent theatrical figure S. Michaels noted: «The past of a Jewish actor is as bleak as that of his audience. The harsh and cruel way of life for a long time hindered their meeting, the actor and the spectator. However, finally, fifty years ago this meeting took place. Their spiritual world was equally low. The stage material is poor, an actor who has just separated himself from the viewer, differs little from him in both technique and ability to act as a hypocrite. However, the actor appeared to be a worthy viewer - he was a full-time shopkeeper, a man of the household, a tradesman. He became his master, his ethical legislator. He sought solace and assertion in the theater. And the actor sang to him» ${ }^{24}$.

These confessions of a well-known Jewish actor and director coincide with the confession of the actress of the Jewish theater of Mrs. V. Zaslavskaya: and for the first time I created for the Jewish scene the role of "Khasi Orphans», and about other Jewish types who have the right to be named exemplary. We tried to click, to lead a mass, but as you can see, forced to follow her. This does not mean that the fate of the Jewish theater has been resolved. I am deeply convinced that even now, if the case had a practical basis, a «joint stock» or a «mutual» company, now it would be possible to combat the power of operetta. But the interesting thing is that other provincial cities require drama, and only serious ideological things. In Odessa, the operetta is flourishing! Amazingly! Impoverished! But the authors are few! It was Gordin, and he died! The rest is all pale! As for the future of Jewish theater, there can be no two thoughts about this.Sooner or later, but the Jewish theater will gain citizenship rights, and then more talented authors and a more regular audience will emerge!» ${ }^{25}$. It must be stated that such confidence in the future of Jewish theater was astounding. But in fact, in about a decade, a professional Jewish theater is emerging that is steadily

${ }^{23}$ Міллер Є.М. «Одеський огляд», 1909 р. № 332. С. 6.

${ }^{24}$ Михоэлс С. М. Статьи, беседы, речи: Статьи и воспоминания о Михоэлсе. Вступ. статья, ред. и примечания К. Л. Рудницкого., 3-е издание., доп. М.: Искусство, 1981. 557 с.

25 «Жизнь искусства». 1922 г. № 36.3 с. 
evolving, gaining strength, going beyond the Jewish scene. The playwrights, directors, talented actors appear in the theater.

\section{XX century - forecasts, problems and aspirations}

The beginning of the twenties of the twentieth century, characterized by the emergence of a significant number of theater studios throughout Ukraine, including in Odessa (1922). Theatrical studios were created by unemployed actors. Lack of professional directors and actors, poorly thought out repertoire, heterogeneity of corpses led to conflicts. Such corpses did not exist for a long time. Spectator Magazine tells the story of the establishment of a Jewish theater in Odessa: «A small troupe of Jewish artists has formed a collective whose task is to serve the Jewish masses. The troupe is performing on the outskirts, choosing social plays. Performed by artist Basmanov, Authorized Comrade Kotlerman. With the addition of the troupe with new forces, it is located in one of the central theaters». ${ }^{16}$ The same issue of the magazine is about the beginning of the work of the acting parliament.Forty delegates were present at the convention.The Stolyarov-led congress noted the plight of Jewish and Ukrainian actors. It was proposed to open permanent Ukrainian and Jewish theaters in Odessa, because «...the absence of a Ukrainian and Jewish theater troupe in such a large theater center as Odess» ${ }^{16}$.

After a while, the Jewish team received a room at the Mirror of Life theater, but the problems remained: «The troupe is not impressed with known names and talents, but it is completed well, and the performances are performed in full house. The plays are old. Ordinary Jewish songs with screams, shouts, shots, blood. Plays are frivolous, idle, bourgeois content. There are no new Jewish plays. He puts the traditional Basmanov - Di istifmame, Zurik Funtorge, Der ehive bucher, and others like that, because the bourgeois audience is brought up on these plays, has become obsessed with them and sees the reflection of their own lives. However, director Basmanov tries his best to smooth the sharp corners, reduce the amount of blood, shots, and refine the characters, but still the mold remains moldy» ${ }^{26}$.

Prominent literary and artistic critic of the late nineteenth - early twentieth centuries. Akim Volynskyi (Chaim Flexer) thus characterizes the dramatic twenties and the place of theatrical art in them: "When a country is broken and humiliated or destroyed, the theater falls fatal.The

${ }^{26}$ «Глядач». 1922 р. № 6 - 8 с.; № 8 - 9 с.; № 9 - 8 с.; № 10 - 7 с. 
scene follows, fair melodies, rough farces, clowns» ${ }^{27}$. He calls for the theater to be «a place of healing for the soul».

Until the thirties, the Odessa Jewish Theater existed in search of new stage techniques and in disputes between disparate corpses.The dream of M. Fischon and W. Zaslavskaya about the future of Jewish theater began to come to fruition: the theater found its audience, improved the repertoire, came contemporary creative directors, appeared talented actors who sought to learn, improving the professional level. The life of Jewish theater in Odessa is widely covered in the city press. Tours of the Odessa Jewish Theater are a success, and the Odessa spectator emotionally meets the tour of the Jewish Theater of Belarus, which showed performances in Odessa: «Bar-Kohba» (S. Galkin), «Sulamif» (A. Goldfaden), milkman «(Sholom Aleichem), «People in White Coats»(S. Kingsley), «Leibke Soldiers»(I. Levin).

In 1939, the theater celebrated outstanding dates dedicated to the five years of the merger of the Odessa and Vinnytsia Jewish theaters, which made it possible to replenish the Odessa State Jewish Theater with new forces and to make the repertoire more interesting and the 20th anniversary of the Moscow State University. As part of these holidays, a solemn meeting of writers, journalists, and art workers took place. Theatrical figures with reports on the creative path of the Odessa State were made by I. Drucker and artistic director E. Leiter.The theater noted significant dates by the resolution of the play «Girl from Moscow» by A. Huberman. In November 1939 the Odessa State Committee celebrated another solemn holiday - the centenary of the birth of the founder of the Jewish Theater A. Goldfaden.His famous play «Witchcraft» - one of the most popular plays - was shown. In fact, it is a musical comedy, a vaudeville satire for the life of local Jewishness. «Performance directors - M. Meyerson and E. Leiter gave the performance a light, dynamic feel.Decorative installations, stylish Memel, successful use in the mass scenes of a small stage - all this speaks to the taste and skills of the producers.Lots of music material, instrumental composer J. Feintuh.The role of Baba Yahne was played by actor Brandesko, according to the tradition of the National Theater.The production was a success, «the Black Sea Commune wrote». ${ }^{28}$ This newspaper also emphasized the

27 Волынский А. Еврейский театр. Статья 2. Походный ковчег. «Жизнь искусства». Пг., 1923. № 28. 2-4 с.

28 . «Чорноморська комуна». 1939. № 2-135. 3 с. 
diversity of the repertoire: "Led by its leader Comrade E. Leiter theater seeks to draw up a repertoire plan so that it meets the viewer's requirements. Jewish classical literature is represented by the plays of Scholom - Aleichem «Stepen Libe», «Tevier der Milhiker» and A. Goldfaden's play «Don't Be Like Me». The European Classical Playwriting is presented by L. Feuchtwanger, The Oppenheim Family, and K. Goldoni, The Tractor Room. ${ }^{19}$

The Odessa State Department, under the leadership of E. Leiter, successfully worked in the city before the Great Patriotic War, then was evacuated to Tashkent and, on returning, resumed its activities to the delight of the Odessans.But the city's post-war press paid less attention to theater, and subsequently began an anti-Semitic campaign to combat cosmopolitanism. Art persecution, arrests, and liberation began. On May 4, 1948, the Jewish Odessa State Theater played its latest Freilechs performance, which concluded a whole stage in the activities of the national theater.

In the eighties and nineties of the twentieth century, the city's theater artists tried to revive the Jewish National Theater in Odessa, but at best, it came down to the creation of amateur Jewish theater groups and groups. Later, Jewish-themed plays appear on other Odessa theaters. In 1985 at the Ukrainian Theater of Odessa a play «Tevye-milkman» was staged according to Sholom-Aleichem (directed by I. Ravitsky), that is five years earlier than at the Kiev Theater of I Franko (1990), where the famous role was played by the famous Ukrainian actor B. Stupka and which became a prominent event in the history of Ukrainian theater. In 2006, the Russian Drama Theater showed a play based on a novel by renowned French writer of Jewish origin R. Gary, «The Dance of Genghis-Chaim», which became an event in the theatrical life of the city. The director of the play is the famous Odessa actor O. Shkolnyk, who a few years later staged «Random Happiness» based on the works of J. Singer, translated from Yiddish. His interest in the work of R. Harry lies in the biography of the classic French literature of the twentieth century. «Son of Vilensky tradesman and actress of Odessa; military pilot, resistance member, friend of Charles de Gaulle; a prominent diplomat, he has written more than thirty novels and is known as the winner of two Honkurov Prizes». ${ }^{29}$ The Genghis-Chaim Dance is the most significant work in the writer's work. Director A. Shkolnik and

29 Бржестовская Н. Тень Чингиз-Хаима. «Культура» от 29 мая 2006. № $117-118.5$ c. 
production director B. Antin based on the best samples of Jewish theater of the 20-40s successfully created the atmosphere of the play (closed stage space, limited number of objects on stage) and symbolically developed the characters of the characters. The Odessa audience received the performance warmly, the premiere was sold out, this performance was positively noted by the Odessa critic. But these isolated performances of Jewish life, staged by Odessa theaters over the last twenty years, certainly cannot meet the demand of the Jewish public in the city.

\section{CONCLUSIONS}

Theoretically, Jewish traditional theater is entitled to revival. This theater should be a theater of Jewish culture. His scenic means must not «portray something Jewis» but grow from the same roots as all Jewish culture. He must carry out a Jewish mission in the world, be Jewish «soulful» in which «a believing Jew, without compromising on his own upbringing and conviction, can be present both in the auditorium and on stage». In other words, «..a Jewish theater is a theater whose artistic narrative embodies the Jewish tradition, and expressive stage aids do not violate the ethical and aesthetic norms of that tradition» ${ }^{30}$.

In examining the problem of the revival of Jewish theater, we have analyzed objective and subjective factors. Among the objective factors behind the revival of the Jewish National Theater are: equality in the rights of national and cultural development guaranteed by the Constitution of Independent Ukraine to all nationalities; the opportunity to seek financial assistance from the international Jewish community if necessary; theoretical foundations of the revival of theater art, developed by scientists. However, the factors that testify to the great difficulty in reviving the Jewish National Theater in Odessa are even more serious. First, the number of Jews who lived in Ukraine, and in particular in Odessa, decreased almost three times during the three waves of emigration to other countries. We can no longer speak about the ethnic group of Jews, but only about the Jewish diaspora in Ukraine «qualitative and quantitative dispersion of an ethnic group that is losing compact settlement in one region» ${ }^{31}$. «Today, the «revival» is rather support for the minimal national and cultural needs of the disappearing

\footnotetext{
30 «Театральний тиждень». 1926 р. № 2 (33). 6 с.; № 4 (35). 3 с.

${ }^{31}$ Новая еврейская школа. Педагогический альманах: № 12 / Ламэд; Отв. ред. Ротман X. // Ривка Менович. Еврейский театр? Мыслимо ли это? С.-Петербург, 2002. 336 с.
} 
Jewish diaspora in Ukraine» ${ }^{32}$. The process of revival cannot be interpreted as the resuscitation of the past. It is, first and foremost, a psychological process when a nation must go through the maturation of its own chronotope as a system of ideas about the historical past of a people living in a foreign country, its present and future existence, surrounded by other nations and minorities. Only in this way can the lifegiving ties of the broken tradition be strengthened, and the continuity of generations restored, reviving the «cultural matrix of the Jewish mentality, the inherent value system, special spirituality» ${ }^{33}$.

\section{SUMMARY}

The study is aimed at studying the scientific concepts of the existence of the Jewish theater, its role in the development of the theatrical art of Ukraine and Odessa, as well as the possibilities of its revival in the modern cultural space. Analysis of scientific, methodical, artistic and memoir literature, archival and newspaper materials, allowed to determine that Jewish theatrical art is an original space-time system, which lives certain stages evolutionary development. We have identified objective and subjective factors of the impossibility of the existence of a professional stationary, repertory, national Jewish theater in Ukraine and Odessa.

\section{REFERENCES}

1. Волынский А. Еврейский театр. Статья 1. Ипокрит. «Жизнь искусства». Л., 1925. № 27 (901). 2-4 с.

2. Волынский А. Еврейский театр. Статья 2. Походный ковчег.«Жизнь искусства». Пг., 1923. № 28. 2-4 с.

3. Голота В. В. Театральная Одесса. К.: Мыстэцтво, 1990. 245 с.

4. «Глядач». 1922 р. № $6-8$ с.; № $8-9$ с.; № $9-8$ с.; № $10-7$ с.

5. «Відомості Одеського градоначальства». 1880 р. 1 січня. 3 с.

6. Гальперин М. «Рассвет». СПб.1880., № 5.168-171 с.

7. «Відомості Одеського градоначальства». 1879 р. № 50. 251.2 с.

8. Файль И. Жизнь еврейского актера. М.: Всероссийское театральное общество, 1938.98 с.

${ }^{32}$ Финберг Л. К. Еврейские проблемы и украинское общество. Сб. «Пам'ятати заради життя». К, 126 с.

33 Ляховицький Ю. Черная книга Холокоста и агония еврейского галута. Сб. «Пам’ятати заради життя». К,1993.158 с. 
9. Гольдштейн Д. Еврейская труппа П. Гиршбейна. Театральные вести. № 1 / 31 января / 1909 г. 2 с.

10. Перец Гиршбейн. «Обручение». Одесские новости, 1909. 5 с.

11.Биневич Е. Гиршбейн П.: Рождение и гибель его театра. «Народ мой». № 23 (315) от 15.12.2003. 7 с.

12. «Відомості Одеського градоначальства». 1881 р. № 2, 3, 4, 7 / від 2 січня до 10 січня. 3 с.

13. «Театр». 1940 р. № 3 - 157 с.; № 5 - 183 с.; № 7 - 160 с.; № 12 - 46-49 c.

14. Міллєр Є.М. «Одеський огляд», 1909 р. № 332. - с. 6.

15. Михоэлс С. М. Статьи, беседы, речи: Статьи и воспоминания о Михоэлсе. Вступ. статья, ред. и примечания К. Л. Рудницкого., 3-е издание., доп. М.: Искусство, 1981. 557 с.

16. «Жизнь искусства». 1922 г. № 36.3 с.

17. «Глядач». 1922 р. № $6-8$ с.; № 8 - 9 с.; № 9 - 8 с.; № $10-7$ с.

18. Волынский А. Еврейский театр. Статья 2. Походный ковчег. «Жизнь искусства». Пг., 1923. № 28. 2-4 с.

19. «Чорноморська комуна». 1939. № 2-135. 3 с.

20. Бржестовская Н. Тень Чингиз-Хаима. «Культура» от 29 мая 2006. № 117-118. 5 c.

21. «Театральний тиждень». 1926 р. № 2 (33). - 6 с.; № 4 (35). - 3 с.

22. Новая еврейская школа. Педагогический альманах: № $12 /$ Ламэд; Отв. ред. Ротман Х. Ривка Менович. Еврейский театр? Мыслимо ли это?.С.-Петербург, 2002. 336 с.

23. Финберг Л. К. Еврейские проблемы и украинское общество. Сб. «Пам'ятати заради життя». К, 1993. 126 с.

24. Ляховицький Ю. Черная книга Холокоста и агония еврейского галута. Сб. «Пам’ятати заради життя». К,1993.158 с.

\section{Information about the author: Ovcharenko T. S.,}

Candidate of Cultural Studies, Associate Professor of the Department of Cultural Studies, art and philosophy of culture Odessa National Polytechnic University 1, Shevchenko av., Odesa, 65044, Ukraine 
DOI https://doi.org/10.36059/978-966-397-215-2/84-110

\section{SUCCESSFUL SPEECH: PLANNING AND PREPARATION}

\section{Ovchynnikova A. P.}

\section{INTRODUCTION}

Good orator's skills are vital for politicians or lecturers, but not only for them. We all heard that people judge by appearance, and while your looks is what the others first see about you, your speech is "the mind's appearance", it is what allows people to make some first conclusions about your personality and inner world. We never get the second chance to make good first impression: whenever you meet people for the first time, you have to say at least a couple of words, so the people first see you - make some judgments from the way you look and then hear you get some idea about what kind of person you are.

It is even more essential when you present your ideas to a group of listeners - audience (have to make a public speech): the way you pronounce the words, have (or do not have) eye-contact with the listeners, put the ideas in order, give some supporting information, affects the audience's perception of your speech and you as an orator. Mastering public speaking skills provides you with great advantage of open and effortless communication.

Therefore, any public speech has to be structured and prepared in advance to minimize the influence of the current moment on the speaker's confidence and thoughts, to save the main idea of the performance and to make that good impression. What an orator should know before planning a speech? Let us discuss the essential steps to successful speech preparation.

\section{Selecting and Analyzing the Subject of the Talk}

One of the most difficult questions a lot of speakers face is choosing a subject. The invitation to speak gives you a lot of space to decide for yourself what the emphasis of your talk should be. In order to select a subject that is appropriate to the rhetorical situation, you should follow some guidelines.

First of all, select a subject you already know something about. Research is easier if you know some facts about the subject, because you 
have a better idea regarding potential sources of information. Selecting a familiar topic also increases your personal self- confidence. Then, a subject you have selected should interest you and your prospective audience. Resist the temptation to choose a subject that is of greater interest for you listeners than for you. This may be a disasterous choice as your presentation will reveal the lack of enthusiasm. Conversely, talking without regard to your audience may leave you with the subject that interests only one person in an auditorium - you! So, you need to balance your needs and concerns with those of your audience. A topic must be of a particular interest for listeners, if: it concerns issues that are important for most of people (health, happiness, success), it gives solutions to some problems the listeners face, it provides opinions on a controversial issue or presents information about a misunderstood phenomenon. Finally, a topic must be appropriate for the speaking occasion. Consider whether the occasion is the right setting for what you are going to accomplish. A talk on body-building may be interesting for you group-mates in the speech class, but it may not be appropriate at the dedication of a new senior citizens' centre, however a speech on the benefits of exercising at any age will get the attention of various age and gender groups.

Your speech topic may be limited by the group you will speak to; in a classroom the instructor might limit your choice by requiring to consider only certain issues. Whether the topic is a free choice or a part of the assignment, your speech must reflect interests you and the listeners share, and it must be appropriate to the occasion on which you are going to talk.

A general subject is of a little value until it is narrowed down to a manageable size. Narrow the subject to be sure you can discuss it sufficiently in the time allowed for the speech. Constrict the subject to meet the specific anticipations of the audience. Gauge your subject to the comprehensive level of the listeners. If you are going to discuss some technological or scientific innovations with a group of non-experts, focus on basic principles of their work (use) and possible applications, which might attract more attention than speaking about some technicalities. If the audience is a group of professionals, the complexity of the material you present will be completely different. 


\section{Analyzing Audience and Occasion}

Centuries ago, public speaking was mostly the Art which was bridging the gap between Past and Present, allowing people to pass on cultural heritage (e.g. myths and legends) from one generation to another; then the Art of oration became the means of conveying ideas from one person to a group of people. Nowadays, with all the modern communication technology, the main task of a public speech is somehow different. When planning a speech, you know exactly what your speech is supposed to do for your audience. Unless you decide what effect your words are to have your speech will lack direction and effectiveness. So, in the modern world public speaking is audience centered.

You always speak to affect the others in some ways. So, you need to know as much as possible about those who is going to listen to your talk. According to L. Fletcher, a speaker should analyze the audience just after he/she has chosen a general topic of a speech, and only on completing this analysis, one can make any further decisions on gathering and organizing the material, planning the speech, including the specifics and other.

First of all, the audience has to be analyzed demographically, i.e. on the basis of the common social and physical traits of its members. An experienced speaker tries to find out the age, gender, education, cultural background of the listeners in advance.

Teenagers, middle-aged listeners and the retired will definitely have different interests and background knowledge, and while a talk on the modern IT advancements might contain more familiar information for the representatives of the first two groups, a speech about the pros and cons of early retirement may be interesting only to the third. If you are giving a talk in front of the mixed-aged audience, think what in your speech can be more appealing to one or another age group.

Despite all the liberation movements, your choice of the facts and style should also be affected by the sex of the audience. It is clear that a skillful speaker will want to speak differently to mostly female (or male) listeners. Beware of the topics which may divide the audience along the gender line!

You should also adapt your speech to the educational level of the listeners. First of all, find out how much the audience may already know about the subject. Will your information be new and valuable for them? As an expert you might have the profound knowledge of the subject and wand to make your talk as informative as you can, however, if you overload it with complicated descriptions, terms, technical jargon and 
specifics, non-professional listeners may lose interest in what you say very soon after the beginning.

When you know that your listeners belong to a particular cultural or ethnic group, it also helps you to adjust your speaking to them and even to choose appropriate clothes.

"Demographic analysis can help you select and phrase your key ideas, and it sensitizes you to crucial factors that may influence your choice of themes, examples..."1

Psychological analysis of your audience involves getting to know your listeners' attitudes, beliefs and values. Bearing in fact such factors will help you understand what your audience's attitude to the subject of the talk and to you as a speaker might be. You should, for instance, find out which of their beliefs could make the listeners supportive of your views and which may urge them to contradict your ideas; then, you analyze if the latter are so called fixed (resistant to change) beliefs or variable ones. After that it is easier for you to organize the material in the way which allows influencing and changing their variable beliefs to go along with your ideas and claims.

So, analyzing you audience's psychological profile will help you frame your ideas, find appropriate supportive material and formulate adequate personal expectations of their possible reaction to your speech.

Another essential step in a speech preparation is the analysis of the speaking situation or occasion. An occasion is "a set of activities that occurs in a time and place set aside expressly to fulfill the collective goal of people who have been taught of the special meaning of this activity"2.

R. Zeoli supposes that apart from analyzing the audience demographically, a speaker should also realize what he/she expects from the listeners and answer such questions as: "What traits do I have in common with this audience? What is the message I going to convey to this audience? What do I want the audience to say about my speech when it is over? What do I want the audience to feel about my speech when it concludes? What do I hope to accomplish with this speech?”3.

L.Fletcher speaks of six important points a speaker should consider when analyzing the speaking situation, they are the following: 1) the

\footnotetext{
${ }^{1}$ Principles and Types of Speech Communication e. / Rayme McKerrow...- 14th edition. - Longman, 2000. P. 99.

${ }^{2}$ Ibid. P. 107.

${ }^{3}$ Zeoli R. Seven Principles of Public Speaking/ R. Zeoli. - Skyhorse Publishing, 2008. P. 39.
} 
purpose of the meeting; 2) the place where it is going to be held; 3) the facilities you may use (e. g. a lectern, a board, air-conditioning); 4) the time when you will talk (people's attention will differ in the morning and at the end of a workday); 5) what other events may be on the program; 6) what is after your speech.

The authors of "Principles and Types of Speech Communication" emphasize that the most important for people speech situations are: regular occasions, such as religious services or days of remembrance, these events occur at special times and often in special places (e.g. places of warship) designed to capture the value orientations of the audience, the occasions intended to meet the needs of particular groups of people (worship, justice, remembrance, recognition to leadership, etc.) Most speech occasions are governed by the rules, roles (duties of the participants), and assessment of a speaker' competency. Knowing and understanding what is expected from you as a speaker are signs of belonging to this particular group. As you face audience's expectation you may:

a) ignore the rules ( to make it work either a speech should of great interest for the listeners or a speaker should be a prominent orator to make the audience take no notice of his/her rules violation);

b) cave in (accept all the rule even if they go against you own beliefs and opinions, which may be as dangerous as the first way);

c) adapt to the rules (accept the rules that you do not find contradicting to your values).

\section{Choosing the Type of the Speech in Accordance with}

\section{a Speaker's Goals}

In the theory of Speech Communication according to general purposes of the speaker "all the ... speeches are reducible to four; every speech being intended to enlighten the understanding, to please the imagination, to move the passion, or to influence the will" ${ }^{4}$. In other words, all the variety of public orations can be condensed to four main types: a speech to inform, a speech to persuade, a speech in order to actuate, and a speech to entertain, performed on special occasions (including speeches of introduction, tribute, nomination, and speeches to create goodwill). Although these types are not mutually exclusive, they are sufficiently discrete to be regarded as individual ones.

${ }^{4}$ Principles and Types of Speech Communication e. / Rayme McKerrow... 14th edition. - Longman, 2000. P. 295. 
General purpose of a speech to inform is to help listeners understand the idea. This type of speeches is employed by teachers explaining new topics, or officials when they seek to explain their actions to the public. Conveying new information changes the level or quality of knowledge your listeners possess. So, the message must be comprehensive, accurate and timely to accomplish your informative goal.

The purpose of a speech to persuade or a speech to actuate is to influence listeners' minds or actions. It may be agreed that all the speeches are persuasive to some degree, but in many situations speaker sees persuading the audience as the main communicative goal. Speeches which intend to change beliefs or attitudes are referred to as persuasive speeches. If a speech aims to go further and move the audience to adopt specific action ("join”, "vote” for etc.), it is called a speech of actuation. "To influence or alter your listeners' beliefs or actions, you need to present well-ordered arguments that are supported by facts, figures, examples, and the opinions of experts... To change minds and move people to action, you must be sensitive to both rational and motivation aspects of audience psychology..."

To entertain, amuse, or provide other enjoyment for listeners is the general purpose of various talks on different occasions. A travel lecture, a school reunion, a final of a competition or a local club meeting may provide a necessity to make an entertaining speech: to share unusual experience, to greet the newcomers, to congratulate the winner, etc. A speech to entertain is not just a comic talk; it may employ humor as an attention getter or a way to make people feel at ease, but generally such speeches intend to convey the sense of identity, group community, or express appreciation or/and respect.

\section{Essential Features and Types of Informative Speeches. Motivation Appeals in Informative Speaking}

The main purpose of informative speaking is to provide listeners with new knowledge, i.e. information. Speeches to inform include such subtypes as definitional and instructional speeches, and speeches of demonstration. "Information is a collection of facts associated with some topic... The challenge is to turn this collection of information into human knowledge. This is what informative speaking is about: turning facts into

${ }^{5}$ Principles and Types of Speech Communication e. / Rayme McKerrow... 14th edition. - Longman, 2000. P. 26. 
information and then information into knowledge"6. The authors of "Principles and Types of Public Communication" refer to the TV series character J. Friday as to a role model for an orator giving an informative speech, as he "put (the) facts into a coherent order than turned them into elements of a scenario - a story of a crime... Only after that information was patterned and hooked in cause-effect chains, and only after those chains were contextualized into the lives of particular people, did the fact produce the story. Without structuring, clarifying and interpreting facts, the information at hand is all but useless" ${ }^{7}$.

To make the most of the informative speaking an orator should think about the answers two such questions as: 1) what must the knowledge I give my listeners do to them? 2) why will they find it essential (interesting, useful, important) to listen to my talk? So, a speaker must consider the motives people may have for listening to this particular speech. Human behavior can be divided into two categories: activities that result from biological needs and acts that derive from social motives. The latter are individual goals or behaviors that come out of acting in accordance with your understanding of what the others expect or value. According to McClelland there three main types of motives: affiliation motives (they focus on desire to belong to a group), achievement motives (relate to desire for success, adventure, self-fulfillment) and power motives (involve desire to influence other people).

A basic understanding of human motivation and various kinds of appeals can be used to enhance your rhetorical effectiveness. A motivation appeal is an attempt to code or translate these social motives into words.

Affiliation motives are dominated by desire for acceptance or public approval, and in this case an orator can focus on the interpersonal bonds attributed to people, appeal to their feelings of companionship, sympathy, loyalty or tradition. Such phrases as "Nine out of ten people in this case agree that..." or "I hope you will make the same choice as the most prominent specialists in this sphere and...” (or any reference to the ones respected and appreciated in this social group) will make audience feel that taking your side they will do something that may be approved by the others.

${ }^{6}$ Principles and Types of Speech Communication e. / Rayme McKerrow...14th edition. - Longman, 2000. P. 299.

${ }^{7}$ Ibid. P. 298. 
Achievement motives are based on a concern for excellence and prestige; in this situation a speaker's appeals are aimed at individual members of an audience. It is quite hard to do speaking publically or making a group presentation, however, a skillful speaker should be able to make each member of the listening group believe that he/she is the one and only target listener of this particular speech.

Power motives focus on influence or control over the others or the circumstances. With power comes social responsibility; the demand that power be used in socially approved ways to benefit the group or the society. Appeal to power does not mean forcing people to do something, it is about making audience understand that the information you convey will improve their influential position. You need to reconcile the power appeals with those of affiliation to maximize your chance of success.

Usually the choice of appeals depends on the type of a speech one is going to give and the demographic characteristics of the listeners. Worked by an expensive and skilful speaker the motives can convert the individuals in the audience into a cohesive group, ready to think in a way consistent with a specific purpose. When speaking in the court a lawyer should bear in mind that his discourse is intended to reveal the truth on the case and to aid the judges and the jury in reaching the just verdict. So, his speech has to tap into collective motivation.

The goal of an informative speech is to make it easy for listeners to acquire and retain new information, which is why a speaker needs to strive for clarity, the association of new ideas with the old ones, effective packaging of the ideas and relevant visualization. Clarity is the result of two factors - the accurate wording and effective organization (see the previous lectures). Association and visualization help make information relevant to the interests, anxieties and needs of the listeners. You cannot associate new ideas with familiar ones if you do not know what is familiar for them. To visualize information is to depict its place in someone's life, so use metaphor, imagery and ostensive definition.

\section{Speeches to Persuade and Actuate. Enhancing Personal Credibility}

"The speaker who persuades makes a very different demand on an audience than the speaker who informs. Informative communicators are satisfied when listeners understand what's been said. Persuaders, 
however, attempt to influence listeners' thoughts or actions... The general purpose of all persuaders is to convince audience in something" ${ }^{8}$. Some problems that a speaker may face as a persuader are the following:

1. The need to adapt your work to listeners' psychological state.

2. The selection of motivation appeals that will work for the particular audience.

3. Facing the diverse listeners in the audience.

Psychological state refers to the complex of beliefs, attitudes and values that listeners bring to a speech occasion. Few speakers scientifically assess psychological state of the audience; however, good listeners' analysis allows you to adjust your appeals and plans of action accordingly. Beliefs and attitudes are based on the traditions and customs of a group the people attribute themselves to. The collections of people or organizations that affect individuals' views and attitudes are called reference groups. Each person voluntary or involuntary is a member of some reference groups (you may not hold actual membership but be a part of a group just by sharing their beliefs and views). Aligning your views those of positive membership groups important to the listeners helps you to create long-lasting acceptance. However, a speaker usually faces various people listening to him/her, so you must work several reference groups into most speeches to reach different segments of the audience.

An audience can have five possible attitudes towards an orators topic and views: 1) favourable but not aroused to act; 2) apathetic towards the situation; 3) interested but undecided what to do; 4) interested in the situation but hostile to the speaker's opinion; 5) hostile to any change from the present state of affairs.

A message that incorporates two sides of a controversial issue might be the most effective if you include arguments which refute the side opposing your own position. A one-side message, which focuses on the argument in favour of your position, may be more efficient than just the outline of the two sides of an argumentative issue without refutation of the opposing to your views point.

Also, you may have to deal with the saliency of attitudes and opinions. Saliency refers to the current interest level of a belief or

${ }^{8}$ Principles and Types of Speech Communication e. / Rayme McKerrow...14th edition. - Longman, 2000. P. 330. 
attitude for an individual. The more often the issue is in the new or on the front pages, the more likely the audience will have opinions about it. The more they know the more careful you should be selecting and wording your arguments in order to persuade the listeners.

A priory, you may stumble upon the different degree of willingness of audience members to accept your ideas. You cannot expect that all the listeners will see the situation eye to eye with you as a result of your speech. You should strive for incremental change: gradual- step by stepmovement to your goal.

Finally, the higher your credibility, the better are your chances to be a successful persuader. The factors that affect an orator's credibility are: the sense of speaker's expertise, trustworthiness, competency, honesty, friendliness, and personal dynamism.

You can increase your audience's perception of your competence by: 1) carefully setting forth all the competing positions and ideas, relevant to your topic before you come to your own judgment, 2) reviewing various criteria for judgment to show that your positions flow from the accepted criteria, and 3) showing that the steps which you propose will solve the problem you identify in your speech.

Expertise can be shown by: 1) using various sources of information; 2 ) documenting the sources of information, 3) presenting your information in a logical, well-organized way, 4) using clear visual aids when appropriate, 5) providing necessary background information, 6) competently separating causes from effects, long- term from shortterm effects, facts from assumptions, 7) delivering your speech in a calm, self-confident and friendly manner.

You increase sense of sincerity by: 1) showing that you are open to criticism or corrections, 2) showing friendly and warm attitude to the audience, 3) maintaining eye contact with your listeners, 4) recognizing everyone, who has helped you to work on the issue.

An audience's sense of a speaker's dynamism can be enhanced through speaking vibrantly, drawing vivid images and using various expressive means; and expressing your ideas with short, hard-hitting oral stile rather than a long, cumbersome written style.

A sense of friendliness for others can be created by treating yourself and the others as human beings, regardless to how intensely you disagree with them, and talking in terms of the "real world" problems rather than in terms of personalities or ideologies. A public speaker's principle virtue is to be a person who embodies a message and whose own values are expressed in and through this message. 
Any persuasive speech can be attributed to one of the sub-types:

1) a speech of reinforcement (they seek to increase people's adherence to a particular set of values, in such a speech an orator calls up to the original beliefs that caused the listeners to join the particular group);

2) a speech of modification (they seek psychological change in the peoples beliefs, or basic values);

3) a speech of actuation (intended to move apathetic audience to agreed and effective action).

A lawyer often has to combine these types in order to create an oration which will bring about some changes in the judges' and jury's vision of the case considered and make them see the evidence or facts eye-to-eye with him/her.

\section{Gathering Ideas and Information}

When you decided on the subject of the speech or got an assignment to speak on a particular issue from your teacher, boss, or the chairman of a local society, you should not rush right down to the library or start searching the Net at once. The first source for the content of your speech should be your own head. Start by thinking through what you already know about your speech subject.

Write down all the facts and points that come to mind. Make just rough notes. Note your ideas in whatever order you think of them. Don't worry about the sequence. Sorting them out into some logical pattern will be easy if you wait until later.

A speech should present your ideas, your views. Or it should present facts and figures you've discovered. At the very least, your speech should present your own new structure or understanding of a subject or problem. So, start with gathering your ideas and the information you might have already known to support these ideas. They may be your concerns, opinions or even feelings about the subject matter of the prospective talk. And then you will need to find more information - data, facts, specifics to make your speech credible and effective. Specifics serve four main purposes:

1) prove a point

2) clarify a point

3) make a point memorable

4) add interest to your speech 
That's what specifics can do for your speech. There are various types of specifics you can present to increase your speech effectiveness:

1. Examples

2. Quotations

3. Statistics

4. Stories

5. Definitions

6. Comparison

7. Contrasts

8. Audiovisual aids

Not all of those types of information can be used equally as well for each of the four purposes of data we have mentioned. You have to select your information depending on your needs and the speaking situation.

1) Examples are one of the most frequently used-and misused-types of information. Consider the use of an example from a speech given by a student: "Our state camp grounds are too crowded. Last weekend we went camping in a state park, and the tents and trailers were so close together we had no privacy." That example explains what the speaker means by "too crowded." The example also makes the point a bit more memorable-listeners can visualize the problems of people camping close to one another. And that example also serves the fourth purpose of specifics-to add interest to a speech-people like to hear about what others do on vacations. But remember, there's another purpose in using specifics in a speech-to prove a point.

An example is NOT valid proof!

That's how a lot of speakers misuse an example. That's an ineffective-incorrect-use of an example because the speaker is trying to convince listeners on the basis of just one isolated experience.

To use an example to prove a point, the speaker needs to show that the example is truly representative of conditions as they are most of the time.

So do use examples in your speeches. They're valuable. Interesting. But if you use examples to try to prove a point, be sure the examples show a true picture of the situation.

2) A speaker is using a quotation when he presents a statement made by someone else. Usually it's from a person who is an authority or who has special experience with the subject.

Quotations can range from ones you may pick up yourself, or, quotations can be dug out of research reports, reference materials, books, and such. Another way to get quotations for your speeches is to collect 
your own - not only when you're preparing to give a speech, but gathered as you come across them. If you give speeches now and then, it may be worth your time to write down good quotations whenever you find ones that relate to your job, hobbies, or whatever subjects you might speak on.

Quotations are valuable because they add authority to your speech. They tend to show that you're not alone in thinking as you do-that there are experts who say the same thing.

On the other hand, you may notice the big weakness in using quotes. Someone can almost always find someone else to quote who has said just the opposite. When Mediterranean fruit flies infested California orchards, politicians were busy quoting ecologists on the dangers of using sprays to get rid of the dangerous bugs. But other politicians quoted other ecologists who claimed the sprays were not harmful to humans. Who was a listener to believe?

The value of a quotation depends largely on who said it. If the person is knowledgeable, objective, and honest, the quotation may be accepted.

3) Often, the audience can be impressed and persuaded by the language of figures, that is why statistics may be accepted as a criterion of your speech trustworthiness. However, statistics, too, can cause problems for a speaker.

First, some listeners reject all statistics. 'Figures can lie and liars can figure" is a popular line in some circles.

One basis on which to decide if you should use a particular statistic is to consider the source. Will your listeners believe whoever provided the figure? If your listeners are members of the same profession as the source of your statistic, your audience may believe your statistic. On the other hand, if you're speaking to a group of union members, they might not accept a statistic you use from a management source.

Another problem with statistics: They can be very dull! But they don't have to be. For example, president Reagan made a statistic memorable when he spoke to the Joint Session of Congress about his first budget. He said:

"A few weeks ago I called such a figure - a trillion dollars incomprehensible. I've been trying to think of a way to illustrate how big it really is. The best I could come up with is to say that a stack of $\$ 1,000$ bills in your hand only four inches high would make you a millionaire. A trillion dollars would be a stack of $\$ 1,000$ bills seventy-six miles high.” 
Another technique to help your listeners remember numbers is to round them off. An audience doesn't always need the exact figure.

4) Stories: One of the main values in telling a story is that people like to hear about what happens to other people. And many listeners will be more impressed with stories than statistics. The major danger in telling stories is that a speaker can overload them with too many details, so that the audience will lose interest in the main subject before an orator gets close to the point.

5) Definitions are statements of what you mean when you use certain words or phrases. The main value of a definition in a speech is to make sure you and your listeners are considering the same point. In speeches presenting one side or the other of controversial issues, definitions are especially important. Try listening to a couple of people as they talk about their ideas on some debatable topic. Don't let yourself get involved in the argument. Just listen carefully. Often, in just a few minutes, you'll hear that they only seem to have different opinions. What they're not agreeing on, really, may be definitions.

6) Comparisons are often a very effective type of specifics to use in a speech. A comparison presents characteristics, features, or qualities which are similar. Often it may show an audience a connection between what they know and what they don't know. Or a comparison may state a relationship which is a surprise.

7) Contrasts present differences, for example, Liz Carpenter, a writer and an assistant of one of the USA presidents once said: "In 1960 there were three and a half million college students in this country. ... Today there are twelve million"

8) Audiovisual aids can centre the listeners' attention and add more interest to your speech. They often help the listeners understand your point better and remember the main idea for long. Nowadays, with the advance of the modern electronic devices, such as tablet PC and laptop PC, interactive boards and blue -ray video, a speaker has almost unlimited access to a wide range of visual materials. It is essential to feel the measure and not to overload a speech with them when it is not necessary; audio-visual aids should be appropriate to the speaking situation: a short talk that does not contain any complicated information will not definitely require any video support. Also you need to practice using the aids before making a speech in order not to face an unexpected problem turning the equipment on. 


\section{How to Use the Time Effectively. A Typical Speech Format}

One of the secrets of successful professional speakers is the following: "Get your speech organized very clearly-in a few very specific, precise points-and it's much more likely that your audience will get your message."

Failure to know-or use-that secret is usually the main reason so many speeches do not achieve their main goal: to get your listeners to accept your ideas, remember what you say, and take the action you want. According to L. Fletcher there is a format or a general guide for the design of a speech.

This format can be used for a talk on any topic, at any speaking occasion, for any speaking situation, whether you're giving a short, casual talk or presenting a formal appeal to a committee of your state legislature; the general speech planning pattern includes:

\section{Introduction}
A. Attention getter
B. Preview

\section{Discussion}
A. Main Points
B. Arranged logically
C. Supported with data

\section{Conclusion}

\section{A. Review \\ B. Memorable statement}

This format is referred to as the essential key to designing an effective speech by L. Fletcher. Note that it includes three main parts to a speech-the introduction, the discussion, and the conclusion. There are two very good reasons for designing the discussion first, leaving the introduction and the conclusion until later.

First, the discussion contains most of the content of your speech. As a general guide, the length of a speech usually breaks down to be about: $10 \%$ for the Introduction, $75 \%$ for the Discussion and $10 \%$ for the Conclusion.

Thus, for a typical twenty-minute speech, the time you'll have for each main part of a speech would be about:

3 minutes for the Introduction

15 minutes for the Discussion

2 minutes for the Conclusion 
If you consider a five-minute talk, that's all the time you're allowed at many public meetings: the typical introduction of a speaker, announcement of an event, and many other speeches of today are often briefer. The time you have for each part of a five-minute talk is:

45 seconds for the Introduction

3 minutes and 45 seconds for the Discussion

30 seconds for the Conclusion

Remember: while those time guides to the length of a speech work for most speeches, you may have to adjust them in special speaking situations.

The second reason you should plan the discussion part of your speech before you plan the introduction and the conclusion is that it's much easier.

Note that the format states that the first words of your speech should present an attention-getter. That's a statement that will instantly grab the interest of your listeners. However, it's hard to begin planning a speech by first dreaming up a really stimulating opening. It's much easier to go ahead with the design of the rest of your speech - the discussion - while keeping alert to finding that fascinating bit you need to open your speech. In order to organize the discussion part of your speeches, first, you need to decide what form you're going to use as you write down the ideas and information you'll present in your speech. You have three options:

1. A full script

2. An outline

3. Notes

Writing your speech out word-for-word takes much more time and effort. And delivering a speech from a script is difficult. Finally, a speech should be closer to conversation than to written expression. Most speakers find it best - by far - to prepare an outline of what they want to say in a speech. The outline doesn't have to be formal and full sentences are not needed.

After completing an outline of a speech, some speakers then prepare note cards to use while they speak. Others prefer to skip the outline. They find it easier to prepare note cards as they plan their speeches. Either way, your note cards, too, should be specific. When you're standing up there before an audience, trying to remember what to say next, you don't want to look at your note card and find that the next point you've written down is simply. In the pressure of presenting the speech, one word may not be enough to remind you just what you wanted to say about the future. Again: be brief, but specific. 
And write your notes large enough so you won't have any trouble seeing them, even if stage lights are shining in your eyes or there are other distractions. It's far better to use several cards, rather than trying to crowd an entire speech on one card, using tiny writing. Finally, number your cards clearly, to help make sure you keep them in sequence.

Next, remember our format for a speech. Start with the first item in the discussion part of the speech-the main points.

Begin by making a list-a long list-of the points you might present in your speech. The list should include a dozen or so point; take time to make a long list to help insure you'll include all of the significant points you'll want to present. Then cut that list down to the two-to-five best points.

Many listeners are not able to remember more than five points. On the other hand, it is not always efficient to present just one point: if your listeners do not accept this one point, they may reject the rest of the ideas you present. It's much safer to give your listeners at least two points to consider. Then if they doubt one, they still may accept your basic idea.

Your main points should not be confused with your facts. Facts, remember, are the statistics, quotations, and such which support your points-prove them; clarify them make them memorable and more interesting.

\section{Patterns for Internal Speech Organization}

It is essential to sequence your points-put them in the most logical, effective order possible. This is one of the most important steps in planning a speech. Arrange your points clearly and you've greatly increased the chances that your speech will be successful.

According to L. Fletcher, too arrange the main points in your speech, there are four main patterns you can use. They are:

1. Time

2. Space

3. Topic

4. Problem-solution

Which pattern is best? It depends on your speaking situation, the impact you want to make on your listeners, the information you have to present.

1) Time Pattern is the pattern that usually works best if you're talking about how to do something, or about an activity, an historic event, or such. 
For instance, if you're talking about how to plan a trip, you could organize your ideas and information into these main points:

A. Planning before you leave

B. Planning during the trip

C. Planning after the trip

Under that first point - planning before you leave - you might present facts about how to gather information, how to work with a travel agent, how to budget, and such. To support that second point - planning during the trip - you could talk about how to plan for changes that may come up in your schedule, or how to plan side trips that you might find interesting. For the third point - planning after the trip - you might offer tips on how to use what you learned on this trip to improve your next one.

2) Space Pattern is used when you organize the points of your speech on the basis of some physical or geographic sequence. For example, if you're talking about the tax problems in your state, you might organize your ideas this way:

A. Tax problems of coastal towns

B. Tax problems of farm communities

C. Tax problems of major cities

Those points illustrate another major advantage of picking particular pattern for the design of your speech. Once you start sequencing your material, you often discover either one of two, problems.

One: You might be trying to cover far too much material. The solution: limit your topic.

Your second possible problem: You might not really have enough to talk about. What should you do? Either dig out morel material, or expand your topic into related information.

3) Topic Pattern is effective in any speaking situation. It's used more than any other pattern. For a speech about the joys of sailing, your points might be:

A. The lure of the open sea

B. Relaxation at its best

C. A real change of pace

The topic pattern doesn't allow you to be very creative. All you do is present a series of statements, following each with your information. Often, the points don't have much relationship to each other. Sometimes the logic in a topic pattern is harder to follow. The result: Many listeners seem to forget these speeches faster. Still, the topic pattern is a good one 
because it gives the speaker so much flexibility. Whatever your subject, it will fit into the topic pattern.

4) Problem-solution Pattern (or casual pattern) is useful when you're proposing a change or trying to get something improved, offering a new idea, or recommending a plan of action. For example, to argue that deforestation of the Amazon River must stop this pattern is used:

A. Problem

1. Deforestation (cause)

2. Imbalance in the region, air pollution, destructive run-off (effect)

B. Solution: Stop cutting down the woods

A well-constructed problem-solution pattern can be very effective indeed. It presents your ideas in a very logical, very clear sequence. However, in such a speech you should analyze the causes that seem to have produced the problem (effect, consequence) and prove that the action you propose must change the situation, e.g. eliminate the cause. You should think what kind of support would be necessary to illustrate the connection between the cause and the effect, to show that this particular reason has lead to the problematic situation you are trying to solve. Finally, it is better to start your speech with a cause when listeners are generally acquainted with a cause (cause-effect format), and, on the contrary, with an effect if the effect is better-known than a cause.

\section{Using the Motivated Sequence to Organize a Speech}

People actively seek organization in their life, and language is the main means of differentiation and structuring of the world. The words and phrases show relationships between ideas, events and object, and as listeners we depend on a speaker's use of specific phrases to cue us to the sequencing his/her ideas. We look for the same sense of order in a speech as the speaker moves from the central ideas to explanatory points or from claim to reasoning. There is a convenient orientation to how listeners' process structure. It is known as Monroe's Motivated Sequence.

The steps of the motivated sequence conform to a listener's desire for coherence and order. From the listener's perspective, the major reasons for listening can be reduced to two broad classes: reasons serving a person's biological needs, and reasons, supporting a person's social desires. Social motives are individual goals that result from acting in accordance with your understanding of other people's expectations. Your desire to succeed in making a speech, to feel needed by the others, to be 
a person others admire are the examples of social motives. Presenting your ideas in a way that maximizes your listeners' ability to adhere to these social motives will urge them to listen to you more attentively.

The motivated sequence includes five basic steps for the natural progression of audience queries.

1. The Attention Step. The first task of a successful speaker is to get listeners' attention. Surely, you capture your audience's attention through the type of ideas you present. It is essential to begin your speech with a so-called attention getter, a phrase or sentence which will make them think "I want to listen to this". Your manner of delivery also affects the audience's attention. The flexibility of your voice, the variety of gestures and body movements, the impressiveness of your language will definitely push them for listening to your message alertly.

2. The Need Step. A speaker must set forth the reason for the listeners being concerned with the ideas presented, use the supporting materials that demonstrate why listening to him/her is important for the audience. In the need step you have two main goals: to make your subject clear, and to relate your subject to the concern of your audience.

3. The Satisfaction Step. The purpose of this step is to help your listeners understand the information you are presenting. A listener should see how the reasons support a speaker's claim.

4. The Visualization Step. The function of this step is to motivate listeners to feel or act in a certain way. The primary strategy is to project listeners into the future and illustrate vividly the results of accepting or denying the proposed belief or acting or not acting as the speaker directs. This step can be developed in three ways: 1) the positive method of visualization describes the favourable conditions that will prevail if the audience accepts your proposal; 2) the negative method of visualization describes the adverse conditions that will prevail if the listeners will not accept your ideas; 3 ) and the contrast method of visualization combines both positive and negative perspectives of the future.

5. The action step seeks specific action on the part of the audience. You seek in this step to answer the question: "What do you want me to do with this information?" Urging further study of the topic, illustrating a moral point through humour or seeking to strengthen a belief or attitude are the ways the action step is used to answer this question. The action step should be relatively brief.

For example, in a speech to actuate this sequence can be used to lead directly to an action step. 
TOPIC: Urging classmates to join a blood donors' group being formed on the campus.

Attention step: If you had needed an emergency transfusion for a rare blood type in... (place) on the ...(date) you might not have received it.

Need step: Blood drives seldom collect sufficient quantities of blood to meet the emergency needs in our region.

Satisfaction step: A blood donors' association guaranties predictable, steady supplies of blood to medical community.

Visualization step: Without steady supplies of blood our community will face out needless deaths, with it, emergencies can be met with prompt treatment.

Action step: What do I want you to do? - You can help by filling the blood donors' card I'm handing to you.

\section{Planning the Beginning of a Speech}

Although a speaker places the most essential information in the main body of the speech, it is the beginning will definitely influence the audience's desire to listen to him/her. Within the very first moments of your talk a listener makes some judgments about your speech, thinking about it as interesting or boring, relevant or irrelevant, well-prepared or impromptu, etc. You will never get the second chance to create a good first impression. Therefore, the best speakers find it most effective to present an attention-getter first. To put it another way, to get your audience's attention should be the first and total purpose of the opening words of your speech. You need to tie your speech to your listeners' interests to hold their interest, and there are some techniques that aim at this goal. You may choose to start your speech with:

1. Stating a startling fact

2. Asking a question

3. Telling a joke

4. Presenting a quotation

5. Giving an example, illustration, or story

6. Referring to the occasion

7. Pointing to an historic event

8. Complimenting the audience

9. Using a gimmick

10. Emphasizing the importance of the subject

Here are some examples and tips for using each of those techniques.

1. Stating a startling fact 
The power of unusual facts is illustrated by the syndicated column called "The Grab Bag," written by L. M. Boyd. It appears regularly in newspapers throughout the nation. It consists of nothing but a couple of dozen unrelated, uncommon facts. 'Ketchup 150 years ago hereabouts was a patent medicine." "Polls show: ninety-seven percent of university students don't know the words to their school songs."

You could use such facts as attention-getters in your speeches. This approach is especially useful when the listeners are distracted or apathetic. It rivets their attention to the topic of your speech.

2. Asking a question

This is one of the easiest techniques to use. There is always something you can ask your audience about the subject of your speech.

If a visitor from abroad asked you what should be seen in your town, what would you reply?

Do you wonder what causes the many changes in our society today?

But some questions may not be effective attention-getters. Consider these:

Do you know the name of the richest country in the world?

Have you ever noticed how many people wear braided belts?

What might some of your listeners respond-mentally-to those questions? The richest country? Some may think: With my budget problems, who cares?

Such negative reactions to your opening question will make it harder for you to get your audience thinking with you. To be effective, your opening question should get your listeners thinking positively. They should be stimulated, wanting to hear more of what you've got to say.

Questions which get listeners involved with your speech are most effective. Try to get them to listen actively-to think along with you, for instance

If you could-or had to-live the rest of your life in another country, which would you select?

What's the one thing you own that you could absolutely not do without?

3. Telling a joke

Many speakers find that the ideas they present in their speeches are accepted more readily when their audiences are put in a jovial mood. So they open their speeches by telling' a joke.

But don't feel that your speeches must include jokes. Some of us aren't good at telling jokes. Others feel that using humor just isn't their style. A joke poorly told can backfire-help the audience lose confidence 
in you as a speaker. And, of course, many speech subjects are not suitable for jokes.

A basic guide is to be sure your jokes have some logical relationship to your speeches. Everything you say in your speech should, of course, relate directly to the subject of your speech. If you can't find a joke that fits, don't use one.

Still, there are a couple of tricks you can use to make many jokes fit many speech subjects.

One technique is the switch. Comedians sometimes call this "changing the peg." That means changing the setting, characters, or subject of the joke.

Another way to tie a joke to your speech subject is through a transition. That's a phrase, sentence, occasionally, a couple of sentences which link the point of your joke to the point of your speech.

In addition, humor used to open speeches should usually be short and to the point.

Finally, the appropriateness of a joke should be considered carefully.

The point: Study every joke you're thinking about using to make sure it will not offend someone and thereby detract from the success of your speech.

\section{Presenting a quotation}

Quotations are a good way to open a speech-to get the attention of your listeners-because people like to hear what others have said about the subject of your speech. Sometimes it's effective to open a speech with a quotation made years ago about the subject of your speech. But remember the one big weakness in using a quotation. With a little digging, someone can almost always find another quote that says just the opposite of the quote you've used. Often the source of that conflicting quotation is every bit as important, knowledgeable, or respected as the person you've quoted. But then, chances are rare that someone in your audience will be able to remember an opposing quote at the very moment you start your speech.

5. Giving an example, illustration, or story

A real -life accident, a passage from a novel, or a hypothetical illustration can get a speech off to a good start. An illustration should be interesting to your listeners, as well as relevant to the central idea of your speech.

At a management seminar in Stockholm, Loet Velmans, chairman of Hill and Kowlton Inc., began his speech by saying: 
There seems to be something in the human psyche that makes years ending in nine or in zero important. In the nine-ending; years, we tend to look back and assess where we have been. In the zero-ending years, we tend to look forward to see where we're going. Both are fascinating exercises and both assume that there is something magical about an artificial construction called a decade. But the future is important.

His example led clearly, directly, to his statement of the subject of his speech. That's one of the main advantages of beginning a speech with an example, illustration, or story.

Another advantage is that stories about people in particular are especially effective openers for speeches. Again, people like to hear about people.

6. Referring to the occasion

Instead of referring to the subject you may first refer to the occasion that has brought you and your audience together. Beginning your speech with a statement of the reason for the meeting gives the tone to the whole meeting, e.g. the grand or solemn occasion demands serious listening. Or, tell the audience what problem brought about the meeting at which you're speaking.

While this opening is usually not very dramatic or stimulating, it does have the advantage of letting you emphasize the reason you're speaking. You can point to the mutual interest or subject that brought you and the audience together for your speech.

7. Pointing to an historic event

Every day of the year has been the occasion of at least several variedoften quite interesting-events. Many newspapers publish a short column entitled “Today's Almanac.” For October 20, for example, the column listed, among other events:

Today is the 294th day of the year, with 72, days to come.

1977: first takeoff by supersonic Concorde airliner from New York's Kennedy Airport.

1968: Mrs. Jacqueline Kennedy married Aristotle Onassis, the Greek shipping magnate.

1918: Germany accepted terms to end World War I.

One or more of these events can refer to the subject of you talk. If not you can always find some other reference in the interned or in media.

8. Complimenting the audience

This can be a good opener for a speech because we all love to be complimented. But compliments have been used by speakers so often that they've become stale. To be effective, a compliment must be sincere. 
To make it so, it should contain honest praise for specific and worthy features. If you are going to compliment your audience, mention a common goal, a recent honor, or perhaps a successful campaign they've achieved.

\section{Using a gimmick}

Novelty openings-usually presented with the help of a visual or audio aid-can be especially effective attention-getters. They work on more than just the ears of your listeners. They appeal, also, to their eyes, sometimes even to their noses.

Examples from speeches I've heard over the years include:

Tearing a $\$ 100$ bill in half as an attention-getter to a speech on banking.

Starting a controlled fire to introduce a talk on safety.

Releasing a pigeon to fly around the room to introduce a presentation on how to train animals.

What makes such openings effective is their shock value. They are unexpected, usually, because they're used so rarely. A creative gimmick can indeed help make your speech memorable. But there are hazards.

A speaker talking to a group in a small classroom opened a talk about refereeing by firing off a blank in a pistol; his point was importance of knowing the rules. But the loud sound reverberating around the small room hurt the ears of several of his listeners. Others were frightened. Few could concentrate on the words for several minutes. After his speech, there was more talk about his attention-getter than his ideas. Still, such gimmick openings do indeed get the attention of audience. Just be sure you use ones which are safe.

10. Emphasizing the importance of the subject

This opening is last on the list because it's been over-used s much. Furthermore, simply telling an audience that what you have to say is important rarely impresses them. Indeed, if you have $t$ tell them your speech is important, it may well be that it really isn't very important!

Typical of this opening are such lines as:

My topic today is of tremendous importance to every individual here in this hall - and to all the people across the nation as well.

In the next few minutes I'm going to talk to you about the most important decision you'll ever make.

Yes, they do arouse a bit of interest. After reading those, you may be wondering: What comes next? What is the speech about? 
But unless your topic does indeed live up to those introductions, you may have difficulty getting your audience to believe to accept-much of what follows.

As frequently used as this technique is, you'll usually find it better not to tell your audience your subject is important, but to show it to them through the startling statistics, unusual facts, and vivid examples.

The preview of a speech should contain a clear, specific statement of its subject. It should be a sentence or two long. In the preview you can either state the purpose of speaking, the central idea of the speech, or you may briefly list the main points that you included into it.

There are also some tips which allow you to avoid typical mistakes in the speech introduction:

Do not be too long-winded, the introduction should be only $15 \%$ of the entire speech.

Don't antagonize or offend your listeners. Some speakers find it effective to "shock" the audience into listening by starting a speech with a negative opening. It may sometimes work as an attention-getter, however, there are risks of making some listeners reject the ideas that you will present in your speech.

Do not use irrelevant materials. Everything you say should have direct connection with the speech subject.

Don't do a pointless time check; time your speech in rehearsal.

Do not show your ego. Do not speak about yourself unless this information is vital for the subject; do not put the audience by any comments or remarks.

\section{How to Make an Effective Ending of a Speech}

The ending of a speech is not less important than the beginning. The conclusion should be no more than $10 \%$ of the entire speech. A longer ending may be appropriate when a strong appeal for the action by the listeners is needed. To make the review of you speech more effective you should:

1) State that you are about to conclude by saying for example "Let me summarize...”, such a phrase will signal to the audience that they should listen more closely, some of them may even think "That is the part I should remember”.

2) Summarize the main idea of the speech. The summary should be brief and clear, not too wordy. 
3) Repeat your main points. You should say again the two to five points you presented in the discussion part of your speech.

4) It is quite effective to combine the summary with the repetition.

\section{CONCLUSION}

The aims of public performances are different but every speaker may use the same kit of psychological tools to reach their own horizons speaking effectively. We have explored the ways to prepare a consistent and captivating speech to take and hold your listeners' attention during the whole action.

\section{SUMMARY}

A speech is better remembered by the audience when a speaker presents a memorable statement after the review. The techniques which were suggested as attention-getters (stating a startling fact, asking a question, telling a joke, presenting a quotation, giving an example, referring to the occasion, etc.) can also be use at the end of the whole speech. At the end a speaker may as well point to the future which often leads the audience into further discussion. Especially appropriate ending of a speech to persuade is calling the listeners for action (First thing tomorrow be sure you go to vote). If your speech is a part of a conference, discussion or a debate, and there are speakers presenting their ideas after you, consider some tie-ins with whatever may follow your speech.

\section{References}

1.Аверинцев С. С. Риторика и истоки европейской литературной традиции. - М.: Языки русской культуры, 1996. - 447 с.

2. Барт Р. Избранные работы: Семиотика. Поэтика: Пер. с фр. M., 1989.

3. Бредемайер К. Черная риторика: Власть и магия слова / Карстен Бредемайер ; пер. с нем. - 2-е изд. - М.: Альпина Бизнес Букс, 2005. - 224 с.

4. Макдермот Я., Яго В. Практический курс НЛП. М.: Эксмо, 2006. $-464 \mathrm{c}$.

5. Овчиннікова А. П. П'ять кроків до гарноі мови: Мовна комунікація: Техніка мовлення/ А. П. Овчиннікова. - О.: Фенікс, 2008. - 192 c. 
DOI https://doi.org/10.36059/978-966-397-215-2/111-132

\section{FORMATION OF MEDIACULTURE AS A DIRECTION OF SCIENTIFIC RESEARCH}

Uvarova T. I.

\section{INTRODUCTION}

Culture is a continuous process of transformation of information paradigms. A new civilizational turn of the beginning of the XXI century caused by the information technology revolution. Changes have occurred in all areas of culture, including institutional changes the media culture (media culture) is undergoing. The relevance of cultural studies of media culture lies in the scientific understanding of the essence, potential and prospects of the impact of new media on all spheres of life.

\section{The concept of "mediaculture"}

Despite the fact that a new type of culture, which began to take shape with scientific and technological discoveries and related technological changes as early as the twentieth century, mediaculture as a special type of culture of the information society, weathered in an independent direction only in the early twenty-first century. It became the subject of scientific discussions and research by cultural scientists, philosophers and sociologists, etc. In their understanding, media culture becomes a manifestation of culture itself and is interpreted as universal access to culture for people through mass media products.

A significant role in the study of mediaculture functioning belongs to scientists T. Adorno, G. Arneheim, A. Bazen, R. Bart, V. Benjamin, J. Bodriar, J. Derrida, J. Deleuze, S. Zhijek, M. Castells, M. McLuena, H. Marcuse, N. Luman, H. Ortega-and-Gasset, M. Foucault. Foreign scientists (D. Bell, W. Boltz, P. Bourdier, A. Gouldner, Y. Kristeva, C. Levi-Strauss, C. Pierce, G. Pollock, F. de Sossiur, E. Toffler, D. Rushkoff, and R. Harris), Russian scientists (V. Kristeva, C. LeviStrauss, and M. Foucault) also devoted their research to the specifics of media and their impact on society. Bibler, V. Borev, A. Elyakov, I. Erofeeva, M. Zhizhina, A. Kalmykov, N. Kirillova, L. Kohanovo, K. Razlogov, A. Chernykh) and Ukrainian researchers (N. Korableva, 
N. Lupak, D. Sizonov, A. Sobol, V. Sudakova, G. Chmil, R. Shulga, etc.). In spite of the fact that a wide range of problems related to the content, functions and specificity of media have become the object of theoretical attention of a number of scientists, there are still many "white spots" in the research space of this phenomenon, which actualize the need for further scientific research, including the definition of the concept of "mediaculture" and understanding of the peculiarities of "new media" functioning in modern culture.

Marshall McLuen, a Canadian sociologist and publicist, was one of the first to use and introduce the term "media" to a wide range of scientific uses, investigating the daily life of a person in the information society. The term itself comes from the Latin medium - something middle, something that occupies an intermediate position, a middle, a center. In mythological tradition, the medium is a priest, shaman, sorcerer, fortune teller who combined semantic opposition: earth and sky, spirit and body, asserting their existence. In different languages the word medium means "means", "mediator", "medium" and others. Despite its origin, "media" has never been interpreted as a simple "intermediary" in the transmission of information. Especially in modern times, when media does not appear as a participant in a communication act, but can influence all its elements. Most often today, the term "media" refers to the totality of channels for transmitting and storing information of various types.

Mediaculture should be viewed from the perspective of studying two main terms: media and culture. The definition of media is interpreted as a means of communication and transmission of information of various types - from the oldest (gestures, pictures, etc.) to modern ones, using integrated hybrid digital telecommunication networks (Internet, mobile telephony, etc) ${ }^{1}$. Culture is the basis of this phenomenon in the context of its functioning as a sign system, as a "code" through which information about a person in the surrounding world is transmitted.

According to the scientist V. Vozchikov, media culture is a "coded" reality, a symbolic existence of real experience in the form of media messages intended for perception ${ }^{2}$. Media culture is a complex means of human exploration of the surrounding world.

1 Землянова Л. М. Коммуникативистика и средства информации. Англорусский толковый словарь концепций и терминов. Москва, 2004. 416 с., С. 197.

${ }^{2}$ Возчиков В. А. Философия образования и медиакультура информационного общества: дис. ... д-ра филос.: 09.00.11 / Вячеслав Анатольевич Возчиков. - СанктПетербург, 2007. - 413 с, С. 359-360. 
Mediaculture is also understood as "an independent form of culture, generating new languages and meanings" ${ }^{3}$. Mediaculture is seen as "part of the general sphere of human culture. It, like culture as a whole, is designed to regulate human behavior, to organize human activity, knowledge and creativity, to form a field of preservation of traditions and emergence of innovations" ${ }^{4}$. This anti-entropic essence of culture, its ability to develop structures, improve the level of social organization and counteract chaos is reflected in the history of the word culture.

According to S. Alferova, media culture is "a multifunctional type of culture of the modern era. Mediaculture makes it possible to accumulate and multiply public information at a rapid pace and in geometric progression" 5 . The researcher considers modern media culture to be "the guarantor of the nation's social memory, an effective catalyst for the exchange of cultural information and a component of communication between the authorities and society, different countries, nations, social groups, individuals, etc". <..> Mediaculture provides ample opportunities for people to communicate in time and space, overcoming centuries and distances, but the paradox of the current situation is the numerous contacts through the media and, at the same time, the lack of communication, acquires signs as a socio-cultural and psychological problem. Mediaculture is responsible for the process of socialization of the individual, acquisition of social experience, knowledge, norms, ideals inherent in society or a social group. These include customs and traditions, etiquette, laws, that is, everything that together forms complex complexes such as law, morality and ideology. In addition, media culture has become the backbone of today's entertainment industry, which offers

${ }^{3}$ Верховская С. Б. Медиакультура как фактор трансформации сознания // Вестник угроведения № 2 (5), 2011. Философия, социология, політологія. C. 93-99.

${ }^{4}$ Етимологічний словник української мови: В 7 т. - Т. 6: У-Я / Ред. кол.: О. С. Мельничук (гол. ред.), В. Т. Коломієць, Т. Б. Лукінова, Г. П. Півторак, В. Г. Скляренко, О. Б. Ткаченко; Укладачі: Г. П. Півторак, О. Д. Пономарів, I. А. Стоянов, О. Б. Ткаченко, А. М. Шамота. НАН України. Ін-т мовознавства ім. О. О. Потебні. - К.: Наукова думка, 2012. - 568 с., С. 138.

${ }^{5}$ Алферова 3. И., Алферов А. Н., Національне та європейське в сучасній українській медіаосвіті // Культура України. Сер. Мистецтвознавство: зб. наук. пр. / Харків. держ. акад. культури; за заг. ред. В. М. Шейка. - Харків: ХДАК, 2016. - Вип. 53. - 372 с., С. 174-185. 
a wide range of special relaxation means - from films of different genres to interactive computer games ${ }^{6}$.

D. Kellner defines media culture as: "Mediaculture is the culture of images, sounds and images transmitted through certain technical means: radio, film, television, music, printed media such as magazines, newspapers, comics, etc" ${ }^{7}$.

Researchers F. Jamison, J. Bodriard, P. Virillo considered mediaculture as a field of culture, which is associated with the broadcast of dynamic images, which are widely used by modern technical means of recording and transmission of image and sound (film, television, video, multimedia systems).

The notion of mediaculture is seen as part of mass communication. As well as socio-cultural phenomena related to media (world of books, world of television, world of newspapers and magazines, world of radio, world of Internet resources). From a personal point of view - as a human culture, and more narrowly - as a mediaculture of a person - his creative expression and possession of communication tools that ensure full involvement of a person in society.

Mediaculture united peoples, social groups and states. And, to a certain extent, thanks to it, the process of cultural self-consciousness, the definition of one's own unique identity, takes place. So, mediaculture is a social mediator, which establishes links between the structures of society ${ }^{8}$.

Mediaculture in research also appears as a management tool. "It is natural that media are called the "fourth power", given its multifaceted and far-reaching power over people's feelings and consciousness"" .

Summarizing the aforesaid, it can be stated that there is no unambiguous opinion on the definition of "media culture" at present. The majority of authors of scientific works, publications on the issues of

${ }^{6}$ Алферова 3. И., Алферов А. Н., Національне та європейське в сучасній українській медіаосвіті // Культура України. Сер. Мистецтвознавство: зб. наук. пр. / Харків. держ. акад. культури; за заг. ред. В. М. Шейка. - Харків: ХДАК, 2016. - Вип. 53. - 372 с., С. 174-185.

${ }^{7}$ Kellner D. Media Culture: Cultural studies, identity and politics between the modern and postmodern / D. Kellner. - London ; New York, 2000. - 357 p., P. 1-3.

${ }^{8}$ Алферова 3. И., Алферов А. Н., Національне та європейське в сучасній українській медіаосвіті // Культура України. Сер. Мистецтвознавство: зб. наук. пр. / Харків. держ. акад. культури; за заг. ред. В. М. Шейка. - Харків: ХДАК, 2016. - Вип. 53. - 372 с., С .174-185.

${ }^{9}$ Ibid. 
formation and development of information space culture tend to the position, according to which the basis of media culture should be the system (totality) of material and intellectual values in the field of media, the level of development of a personality capable of perceiving, analyzing, evaluating the media text, getting involved in media creativity, learning new knowledge through media means. However, most researchers believe that the most complete definition is presented in the works of N. B. Kirillova. She defines media culture as "a set of information and communication means, material and intellectual values developed by mankind in the course of cultural and historical development that contribute to the formation of public consciousness and socialization of the individual" ${ }^{10}$.

From this point of view, media culture includes a culture of provision and transmission of information, as well as a culture of perception of it. In addition, media culture can, to a certain extent, be an indicator of the level of development of a person capable of engaging in media creativity, learning new knowledge about media, perceiving, analyzing and evaluating media text.

\section{The phenomenon of mediaculture in research approaches}

Modern science is characterized by a growing interest in the theoretical justification and practical formation of mediaculture. A significant number of strategies of media phenomenon research have been defined in the theoretical plane.

The communicative approach allows exploring media culture as a form of communication relations. One of the first to apply this approach was H. McLuen. Proceeding from the fact that communication is one of the key notions of media theory, in H. McLuen's works media culture appears as a set of dissimilar subjects and phenomena of the modern level of cultural development. In essence, he created a new cultural typology, which considered the history of culture through the prism of evolution of types of communication - from tactile and oral through written and printed to audiovisual. M. McLuen explained the notion of communication media in a rather broad, comprehensive way: not only radio, cinema, telephone, but also housing, road, wheel, mirror, clothes, road, etc. This understanding of culture radically shifts the emphasis

${ }^{10}$ Кириллова Н. Б. Что такое медиакультура // ТелеЦЕНТР. 2005. № 4 (12). C.19-21. 
in the study of cultural development, all interactions in it arise before the researcher Culture as a form of communication relations. "All these "technologies", or "mediators", the introduction of which will significantly change the communication of man with the world around him (both natural and social) and reorganizes his way of thinking and way of life," - writes G. McLuen in his paper "Media Understanding: the external expansion of man"11. These "funds" are considered by D. McLuen as "External Extensions" of a person, as a direct technical extension of a person, his body, organs, his abilities. In his book, he wrote that the effect of this expansion occurs much earlier than mankind has time to realize it and understand what happened. "We are moving into the future as the driver of a car who looks only in the rearview mirror when driving," says the author, emphasizing that the impact of the latest technology we begin to realize only when they become obsolete ${ }^{12}$.

Analyzing the dynamics of culture on the basis of a communication approach, YM Lotman wrote that "no culture can do without a single language. The minimum system is formed by a set of two parallel languages - for example, verbal and visual"13. The distribution of information also depends on the choice of language. From the point of view of the choice of the language of communication, media culture is a complex phenomenon, because when broadcasting a message through media channels, several languages are always used simultaneously, which creates different semantic layers, complicates understanding and generates ambiguity of interpretations. "Media speech, like any other language, is technology," wrote G. McLuen.

The civilization approach allows exploring media cultures through the correlation of the notion of "civilization". The development of communication media, in this vein, is considered as a powerful factor in accelerating historical development. Functioning of mass media in each cultural-historical epoch forms the corresponding type of media culture, which creates the image of this epoch. Modern media, which are constantly transformed under the influence of scientific and technological progress, influence the sphere of production, management and communication, and generally accelerate all civilizational processes.

${ }^{11}$ Маклюэн Г. М. Понимание Медиа: Внешние расширения человека / пер. с англ. В. Николаева; закл. ст. М. Вавилова. М.-Жуковский: «КАНОН-прессЦ.», «Кучково поле», 2003. 464 с.

12 Ibid.

${ }^{13}$ Верховская С. Б. Медиакультура как фактор трансформации сознания. С. 98. 
American mediologist Douglas Rushkoff introduces the term "Infosphere", which means numerous means of transmitting and modifying information. The Infosphere, or media space, according to D. Rushkoff, is "a new territory open to human interaction, economic expansion, and especially to social and political machinations" ${ }^{14}$. It is the infosphere that it interprets as a continuation of human species evolution, as an expansion of the planetary ecosystem, as a nutrient environment in which culture develops. That is, according to D. Rushkoff, the only environment in which civilization is able to develop is the media environment. And the power, which a man can be endowed with, is already reduced not to the number of human property, but to the media hour, which he can get. D. Rashkoff notes that the continuously growing media sphere has become quite real. Information that mankind will not be able to manage over time, in his opinion, can lead to significant social changes. Thus, the civilizational approach allows to consider media culture as a subsystem of society. It emerges as a civilizational factor that leads to changes in society, culture, spiritual life of the society.

Anthropological view on the study of media culture focuses on innovative shifts that change the basic for the civilizational development of mankind anthropological characteristics. The man lives in the world filled with meanings and values of creative activity of the community which has constructed the social reality. Norms of behavior, which would be generally accepted, are produced in the process of communication, including through mass media, which smooth out the traditional differences in the worldview of people, mixing private life realities in a common stream. The media are changing the way people perceive the world, think and behave. It informs them about the state of the world, fills their leisure time, and affects the type of culture in society at a certain historical period.

Proponents of E. Durkheim's structural-functional approach concentrate on the problem of public perception of media content, analyze methods of forming collective ideas, in particular, investigating the problem of manipulation of public opinion and considering the possibilities of media integrative function in society. The original concepts of media research belong to M. McLuen ("ecological" concept of "world

${ }^{14}$ Рашкофф Д. Медиавирус. Как поп- культура тайно воздействует на ваше сознание [Электронный ресурс] // Библиотека Гумер - гуманитарные науки. URL: http://www.gumer.info/bibliotek_Buks/ Gurn/Rashk. 
village") ${ }^{15}$, E. Toffler and M. Castells (Post-industrial Information Society concept) ${ }^{16}$, G. Deboru (society of the play) ${ }^{17}$, which are an attempt to create models that describe the regularities of functioning and make it possible to predict the future development of media.

The followers of M. Weber's antipositivist paradigm analyze and build a system of meaning of the rational component in cultural activities, focusing on the issues of media organization and their inclusion in the social organism.

Important for studying the influence of media on the regulation of human behavior is the socio-psychological approach, in which the Freudo-Behavioral Concept of Communication of G. Lassuella is noted ${ }^{18}$ and W. Lippman's concept of public opinion ${ }^{19}$.

The studies of neo-Marxist direction, which pay attention to the symbolic meanings of media texts, considering them through the prism of the relationship between the base and superstructure, in which the media are presented as an element of the superstructure, are quite widely presented. According to the neo-Marxist tradition of the Frankfurt School (M. Horkheimer, T. Adorno) ${ }^{20}$. works by the Birmingham "Centre for Contemporary Cultural Studies" ${ }^{21}$. There is increased attention to the impact of media on cultural formation and development. Media in neo-Marxist tradition are considered not only as a "mouthpiece" of power for propaganda of the prevailing ideology, but also as a part and even a characteristic of culture. In this context, we can

\footnotetext{
${ }^{15}$ McLuhan M., Fiore Q. War and Peace in the Global Village. - N.Y.: Bantam, 1968.

${ }^{16}$ Кастельс М. Информационная эпоха: экономика, общество и культура / Мануэль Кастельс; [пер. с англ. под науч. ред. О. И. Шкаратана]. - М.: ГУ ВШЭ, 2000. - 608 с.

17 Дебор Г. Общество спектакля / Ги Дебор; [пер. с фр. С. Офертаса и М. Якубович]. - М.: Логос, 1999. - 224 с.

18 Лассуєлл Г. Д. Психопатология и політика [Ел. рес.] / Г. Д. Лассуєлл. Режим доступу: http://sbiblio.com/biblio/archive/lasuel_psi.

19 Липпман У. Общественное мнение / Уолтер Липпман; пер. с англ. Т. В. Барчунова, под ред. К. А. Левинсон, К. В. Петренко. - М.: Институт Фонда «Общественное мнение», 2004. - 384 с.

20 Хоркхаймер М., Адорно Т. В. Диалектика просвещения. Филофоские фрагмен- ты / Макс Хоркхаймер, Теодор В. Адорно; [пер. с нем. М. Кузнецова]. М.-СПб.: Медиум, Ювента, 1997. - 312 с.

${ }^{21}$ Черемушкина Е. Ф. Основоположник британських «культурных исследований» Ричард Хогарт. [Електронний ресурс] / Е. Ф. Черемушкина. Режим доступу: http://study-english.info.
} 
consider the concept of the famous French sociologist Pierre Bourdier ${ }^{22}$, who, in his theory of the social field, considers the social space in which the human being functions.

The scientific views presented above demonstrate a variety of interpretations and vectors of research of such a complex and multifaceted phenomenon as mediaculture.

\section{Mediaculture: culturological interpretations of basic concepts}

The notion of mediacultures is associated with a number of notions "mass media", "media space", "new media", "social media", etc. These terms can hardly be called equivalent to the notion of "media culture", as they reflect only one aspect of the existence of this complex phenomenon. Therefore, in our opinion, we should resort to a more precise interpretation of these concepts.

In research media cultures use the term "media space". As a separate scientific phenomenon "media space," Western scientists began to think about it only in the mid-twentieth century. In English-language literature, the concept of "media space" has been used since the $1980 \mathrm{~s}$. In studies by M. McLuen and R. Stults and S. Harrison. In Ukrainian scientific thought, the term "media space" was introduced into scientific circulation in the $90 \mathrm{~s}$ of the 20 th century, primarily due to the fact that this concept is inextricably linked with the terms "media" and "mass media". In spite of the fact that nowadays the term "media space" is widely used in scientific literature, today there is no unambiguous interpretation of the term, which is connected with several factors. "Firstly, next to the concepts of media space "other terms are used as synonymous or close in meaning, in particular "media sphere", "information space", "informationcommunication space", "mass-media space", etc. Secondly, the absence of a generally accepted definition of the notion of "media space" is due to the fact that representatives of various sciences addressed the scientific understanding of the essence of this phenomenon, who considered the "media space" as "human cultural heritage, artificially created environment"'"23, as "a set of organically ordered institutions responsible for the development, collection, processing, design, transmission of

22 Бурдье П. Социология политики / Пьер Бурдье // Социология политики; [пер. с фр. Н.А. Шматко]. - М.: Socio-Logos, 1993. - 336 с.

23 Нові медіа в сучасному суспільстві: культурологічний вимір: монографія / В. М. Судакова, М. Ю. Наумова та ін. - К.: Інститут культурології НАМ України, 2017. - 352 с., С. 24. 
socially significant information through various levels of information technology and information-material complexes that affect a particular social environment, whose representatives are able to perceive and understand information messages ${ }^{24}$.

Consequently, according to the Canadian scientist M. McLuen, "media space is a way for people to expand. In other words, the expansion of human capabilities and, at the same time, the narrowing of space itself, accessibility to viewing and participation in events in different parts of the world" 25 . The scientist points out in his works that the development of technologies creates prerequisites for the formation of a global media space and "the transformation of communication into a productive force, which leads to the need to go beyond the European socio-cultural system and subordinate it to the new global management trends associated with overcoming national and state borders and cultural and civilization processes.

Reflection on the notion of "media space" is also observed in the research of Jean Beaudriard, who in his work "Simulacra and Simulations", paying attention to the impact on the personality of media, concluded that they form a hyper-reality that does not correspond to reality-there is a displacement of reality and its replacement by simulacra - certain iconic symbols that are not related to the basic reality, but form a parallel reality. Mass media, under such conditions, is not just a set of technical means to disseminate the content of information, it is a system of imposing models, so the media strengthen the demonstrative nature of any political action ${ }^{26}$.

The culturological approach considers the media space as part of the symbolic space of signs, which leads to its definition as a hypertext structure. In particular, Arjun Appadurai and Malcolm Waters speak about media space as a special symbolic sphere of culture. At the same time, Appadurai singles out the media space into one of five cultural and symbolic spaces-landscapes-in the global cultural flow. Appadurai's

${ }^{24}$ Нові медіа в сучасному суспільстві: культурологічний вимір: монографія / В. М. Судакова, М. Ю. Наумова та ін. - К.: Інститут культурології НАМ України, 2017. - 352 с., С. 19.

${ }^{25}$ Маклюэн М. Понимание медиа: внешние расширения человека [Электронный ресурс] / Маршалл Маклюэн; [пер. с англ. В. Николаева]. - М.: Канон-Пресс, 2003. - 458 с., С. 301.

${ }^{26}$ Бодріяр Ж. Симулякри і симуляція / Жан Бордіяр. - К.: «Основи», 2004. $-230 \mathrm{c}$. 
media space gets the characteristics of a fluid, unstable space, which is a "building block" of those "imaginary worlds" in which people interact with each other ${ }^{27}$. M. Waters subsequently modifies the classification of flow spaces by A. Appadurai and combines it with the concept of J. Bodrijar's simulacres. Thus, the media space ("sacroprosdtransism" in M. Waters' theory) is one of the "dimensions" of the culture formed by the flow of simulacrum information ${ }^{28}$.

Another angle on "media space" in culurology is its consideration in the aspect of interaction of national cultures. The "media space" can be seen as a "channel of transmission of spiritual values at the level of the world community. $<\ldots>$ All substantive texts that are included in the flows of media space have certain meanings and ideas in mind. <...> Media space is a chaotic system of spiritual and value information, which offers, in accordance with different interests and needs of users, the necessary spiritual and cognitive environment, free from dictate and comfortable for social choice of individuals" - says S. Kulibaba. In his opinion, "the key task of individuals, social groups and the state as a whole is to find drivers in the media space for the transmission of integrating terminal spiritual values" ${ }^{29}$.

Such an understanding of the "media space" is presented in the works of L. Zubanova, who understands the media space as "the value space of modern mass media - the "arena" of value interaction of communication participants, the "tribune" of broadcasting significant guidelines for social development. <...> We are dealing with a special organization of space associated with symbolic forms - a wide range of texts and images that are created and recognized by subjects as semantic constructions that form a cultural order through models of explaining reality" ${ }^{\prime \prime 2}$.

27 Appadurai A. Disjuncture and Difference in the Global Cultural Economy [Electronic resource] / Arjun Appadurai // Theory Culture Society. - 1990. Vol. 7. - P. 295-310. - Access mode www.unc.edu/ jbecks/comps/pdf/appadurai_ disjuncture.pdf (Accessed 20 Febrary 2015) 12. 1, p. 296-299.

${ }^{28}$ Waters M. Globalization / Malcolm Waters. - L.: Routledge. - 1996. - 185 p.

29 Кулибаба С. И. Медиапространство и трансляция духовных ценностей [Электронный ресурс] / Сергей Иванович Кулибаба // Материалы Международ. науч. конф «Медиакультура новой России: методология, технологии, практики» / [под ред. Н. Б. Кирилловой и др.]. - 2007. - Т.2 - С. 125-134. Режим доступа: http://vk.com/doc-54830594_213541276.

${ }^{30}$.Зубанова Л. Б. Современное медиапространство: подходы к пониманию и принципы интерпретации [Электронный ресурс] / Л. Б. Зубанова // Вестник Челябинской государственной академии культуры и искусств. - 2008. - № 2 (14). C. 6-17. Режим доступу: http://elibrary.ru/contents.asp?issueid=521114. 
Culturologists also consider the media space in the context of the new challenges of our time, namely the globalization of the media space. According to N. Kirillova, these are "preservation of national identity in the communicative space", "dialogue of cultures" and "cultural pluralism", "interpretation of cultural heritage", "risks and alternatives of the future culture", "possibility of existence of a single world culture" ${ }^{31}$.

The sociological approach sees the "media space" as a component of a social space with the ability to design social constructions based on specific, inherent means (print and electronic media). In sociology, the idea of media space has been formed through the prism of the influence of mass media as a separate social institution on social processes, the formation of public opinion, political image, etc. Media space is seen as an open system of relations between media producers and consumers, which always takes the form of the social and political structures within which it functions" ${ }^{32}$. Since the media space is a social system, all its structural elements: TV space, radio space, press space, Internet, etc., are interconnected and subject to the general laws of the whole development. Therefore, this approach sees the media space as a special sphere of relations between people and communities (individuals and groups) in the process of collecting, producing, disseminating and consuming information.

Media space, as part of the physical environment, is also viewed through a technological approach, where it is perceived as a collection of databases and databases, technologies for their use, information and telecommunication networks and systems.

From the perspective of journalism theory, synonymous to the notion of media space is the notion of "media environment", which is understood as a set of technical and software media (technical means) that are used to create, record, copy, replicate, store, distribute, perceive and exchange information between the author of the media text and those who perceive it. That is, the media space is a collection of sources from which people receive information and the semantic field that these

${ }^{31}$ Кириллова Н. Б. Многообразие культур в глобальном медиапространстве [Электронный ресурс] / Н. Б. Кириллова // Известия Уральского государственного университета. Сер. 2, Гуманитарные науки. - 2006. - № 47, Вып. 12. - С. 58-68. - Режим доступа : http:// hdl.handle.net/10995/23304

32 Пискун Т. В. Медиапространство как особая социальная структура: к методологии вопроса [Электронный ресурс] / Т. В. Пискун // Режим доступа: www.readera.org/article/medyeaprostranstvo-kak-osobaja-sotsyealnaja-0-10118474.html. 
sources form ${ }^{33}$. In the modern world of intensive information exchanges the media space has turned into an important component of modern society functioning, because it influences the modern culture through all totality of channels of formation, transfer and storage of information.

Obviously, the notion of "media space", from the point of view of its multidimensionality and synthetic character, gravitates towards its interdisciplinary definition. At the same time, it should be noted that despite the ramified web of interpretations, which entangles the definition of the notion of media space, the majority of authors point to the necessity of its integral understanding in connection with the notion of "mass media", since media are an important subject of media space formation.

The concept of "mass media" comes from the lat. Massa - pile and media - medium, medium, medium, mediator. This term has appeared relatively recently. In the domestic culturology, the concept of "mass media" and means of mass communication was more popular, while in the foreign scientific space the concept of "mass media" was used. The term "mass media" (short for "mass communication media") in scientific thought is understood as a set of methods and means by which centralized suppliers transmit, distribute and distribute information and other forms of symbolic communication to a large, diverse and geographically dispersed audience. The term "mass media" so far also applies to organizations that control these technologies, such as television channels or publishing houses.

"Mass media" - is a means of mass communication in society and reaches a fairly wide audience. Characteristic features are appeal to a mass audience, accessibility to a mass audience, and the industrial nature of content production and distribution. The stages of media development are closely linked to changes in society. Thus, the emergence of the first newspapers in the 18th century is most directly connected with the entry into the political arena of a new class - the bourgeoisie, for which they have become a means of realizing economic, political and cultural goals (it was then that the metaphor "fourth power," which recorded their great importance in society, authorship of which is attributed to both English novelist H. Fielding and political philosopher E. Burke). Subsequently, the mass media

33 Литвинович М. Как интернет меняет медиапространство. Интеллектуальная Россия. [Электронный ресурс] / Марина Литвинович // Интерлос. - Режим доступа: www.intelros.ru/intelros/reiting/reyting_09/ material_sofiy/8763-kak-internetmenyaetmediaprostranstvo.html. 
became almost the main instrument of economic and political interactions and conflicts, a necessary prerequisite for the establishment of liberal economy and constitutional democracy, as well as bureaucratic economies, authoritarian and totalitarian political regimes. The development of mass media was in step with progress in social and cultural organisation. "Urbanization, the rise of life standards and free time, the formation of modern bureaucracy and other global socio-cultural processes would have been impossible in the absence of mass media, which is not only one of the symbols of the modern world, but also a very active catalyst for all social changes ${ }^{34}$.

Behind the concept of "mass media" there is a complex and diverse set of structures and activities, each of which has its own way of communication and audience: television, radio, journalism, photojournalism, press, music industry, cinema, sound and video recording, news agencies, publishing business, Internet.

The term "new media" is associated with the notion of "mass media". The emergence of the concept of "new media", with an emphasis on the characteristic of "new media", indicates the beginning of a different stage than the previous one. What has become the driving force and the factor of new shifts in culture, including media culture as one of its important components? The notion of "new media" is connected with the history of mass media development and grand social transformations. First of all, due to the change of the traditional model of information dissemination at the beginning of the XXI century. With the advent of the interactive Internet, the information flow began to be regulated not only by producers, but also directly by consumers of information.

For the first time, the term "new media" appeared at the end of the last century. The starting point of the new media era is considered to be April 19, 1995, when the terrorist attack in the city of Oklahoma American journalists began to actively post all the facts on the Internet. In fact, within one day the global network turned from a simple means of storing information into a fairly strong competitor to television. Thus, the notion of "new media" began to be used to separate

34 Наумова М. Ю. Нові медіа та традиційні 3МІ: моделі співіснування / М. Ю. Наумова // Актуальні проблеми соціології, психології, педагогіки. 2011. - Вип. 13. - С. 86-92. - Режим доступу: http://nbuv.gov.ua/UJRN/apspp_ 2011_13_16. 
traditional media (television, radio and press) from the Internet ${ }^{35}$. Until then, the basis for media - periodicals, radio and television - was analogue and printed media. "However, with the rapid development of digital, network, computer, information, game (and later mobile) technologies and communications, the media have undergone significant transformation. New achievements not only affected traditional media in the classical sense, but also led to the emergence of new media. Based on new, digital media, directly related to the evolution of computers and the Internet, and widely implemented in various spheres, they have become more interactive than traditional media, which also significantly differed from them. However, at the beginning of the emergence of new media, this term was often understood as the actual process of emergence and development of digital and network technologies and communications ${ }^{36}$. As A. Lyakhov put it, "technologies are the environment where media live $<\ldots>$ new media are the ones that live in the wrong place where traditional media exist ${ }^{37}$. So, new media is media based on new technologies. At first glance, everything seems obvious. However, the question of what technologies to refer to the new ones further arises. The Canadian Broadcasting and Telecommunications Commission proposes the following definition: "New media are media services that are distributed over the Internet and include a wide range of communication products and services using video, audio, graphics and alphanumeric text. Such services include, but are not limited to, video games, email, online paging, fax, e-commerce and IP telephony" ${ }^{38}$.

D. McQuale gives the following main characteristics of new media: they are computer-based; they are flexible, hybrid; they have

${ }^{35}$ Рогалева О. С. Новые Медиа: эволюция понятия (аналитический обзор) / О. С. Рогалева, Т. В. Шкайдерова. - Вестн. Омского ун- та, 2015. - № 1. C. 222-225.

${ }^{36}$ Нові медіа в сучасному суспільстві: культурологічний вимір: монографія / В. М. Судакова, М. Ю. Наумова та ін. - К.: Інститут культурології НАМ України, 2017. - 352 с., С. 50.

37 Ляхов О. Доповідь на круглому столі, проведеному 22 листоп. 2012 р. в Києві за ініціативи Громадської Ради при Національній Раді України з питань телебачення та радіомовлення [Електронний ресурс] / О. Ляхов. Режим доступу: http:///www.nrada.dov.ua/2012/22/19.

${ }^{38}$ Проценко Д. Тупчієнко «Огляд підходів до регулювання нових конвергентних аудіовізуальних засобів масової інформації: міжнародний досвід», К. 2012, 112 с. 
interactive potential; they perform both private and public functions; they are characterized by a low degree of regulation; they are internally integrated, non-localized and omnipresent; they have access to other communications; they are an environment for both mass and individual communication $^{39}$.

However, does this imply a gradual withdrawal of traditional media, their destruction by new media? - asks a question in her article ${ }^{40}$. "The answer is definitely no. In fact, there is not a single "deadly" confrontation between traditional and new media, only competition, struggle, rather than even a search for the consumer. The technogenic civilization of the information society implies a new strategy of interrelation between media, information and the Internet. It consists in their mutual influence, which is expressed in the interinetration of media and medialization of the World Wide Web.

Among a large number of definitions of new media, there is an example of their interpretation presented in the WEBopedia dictionary: "New Media" - "a common term for many different forms of electronic communication based on computer technology. Term separates the notion of old (traditional) media, such as printed newspapers and magazines, which represented texts, graphics and photos. New media include: websites; audio and video streaming; all kinds of interactive chats; e-mail; on-line communication; electronic advertising; dvd and cd-rom media; electronic virtual games; integrated databases for the phone, such as Internet telephony; digital broadcasting; mobile communications, etc" ${ }^{41}$. However, although such a definition is generally accepted, technological evolution will obviously still make appropriate adjustments.

So, "new media" is a phenomenon of the modern information space. The content of new media means new forms of communication between content creators and consumers, which is especially evident in "social media" as one of the types of new media.

Social media has since its inception been identified solely with the blogosphere, but today it includes, in addition to blogs, social networks,

39 [McQuail D. Mass Communication Theory / D. McQuail; 6th edition. London: SAGE, 2010. - 632 p., P.41.

40 Нові медіа в сучасному суспільстві: культурологічний вимір: монографія / В. М. Судакова, М. Ю. Наумова та ін. - К.: Інститут культурології НАМ України, 2017. - 352 с., С. 50.

41 Webopedia / new media [Електронний ресурс]. - Режим доступу : http://www.webopedia.com/TERM/N/new_media.html. 
Internet forums, Wikipedia projects, podcasts and videos. There are many definitions of social media. Some identify with social networks, as in the Oxford Dictionary, which defines social media as websites and applications used for social networking. "The Social Media Guide website" has identified around 50 definitions of social media. Andreas Kaplan and Michael Henline define social media as: "Social media is a group of Internet applications that build on the ideological and technological principles of the second web and allow users to create and share content ${ }^{42}$. The possibilities of social media allow users to interact with each other and with society, to create communities.

Social media are distributed to blogs, social networks, data exchange services, social databases, social question and answer sites, referral, social sites.

Social media are understood as online communication in which the individual changes his or her role smoothly and flexibly, acting both as an audience and as a participant. Thus, interactivity and the large amount of content created by users is the main feature of social media. All these characteristics distinguish them among new media and make them social.

\section{CONCLUSIONS}

Modern media actively influence the state of culture. The media world of culture is filled with new meanings, images and signs. The values of the modern man are being reformatted. In modern scientific research, the research of transformation processes caused by technological innovations is becoming more and more relevant, including the scientific understanding of the phenomenon of media culture, the potential and prospects for the impact of new media on all spheres of life.

The study of the formation of media culture as a direction of scientific research, allows us to conclude that media culture is a type of culture of the newest era.

Thus, research into the formation of media culture as a direction of scientific research leads to the conclusion that media culture is a type of culture of the newest era. It should be understood as a set of material and intellectual values in the field of media.

42 Social Media and its Origins [Електронний ресурс] - Режим доступу до ресурсу: http://www.defence.gov.au/pathwaytochange/Docs/SocialMedia/ 1.\%20Social\%20media\%20and\%2 0its\%20origins\%20SM.pdf. 
The scientific views analyzed in this article demonstrate a variety of interpretations and vectors of research of such a complex and multifaceted phenomenon as mediaculture.

In modern times, there is a growing interest in the theoretical basis and practical formation of mediaculture. In research approaches mediaculture is considered as a form of communication relations, a powerful factor of acceleration of historical development, in which the media environment is a way of civilization development, as a factor of anthropological shifts, etc.

We believe that these terms cannot be considered equivalent to the notion of "media culture", as they reflect only one aspect of the existence of this complex phenomenon. Therefore, the article clarified the interpretations of these concepts and established a correlation to the notion of "mediaculture".

\section{SUMMARY}

The article deals with formation of mediaculture as direction of scientific research. Mediaculture becomes a manifestation of culture itself and is interpreted as universal access to culture for people through mass media products. Cultural interpretations of concepts related to modern mediaculture - "mass media", "media space", "new media", "social media", etc.

The article attempts to make a culturological interpretation of the basic concepts of mediaculture - media space, mass media, new media, social media. The definition of the main characteristics of the notions "media space", "mass media", "new media" and "social media" allows concluding that despite the interrelationship and general conceptual orientation, these notions have certain semantic differences. Namely, the media space in the broad sense acts as an asset of culture, an environment of information functioning, which with the development of technologies becomes a global media space. The media are understood as media that function in the media space. "New Media" - a term that began to be actively used with the advent of new interactive electronic publications, new forms of communication for content producers. New media are considered as a set of digital, network, communication technologies in the media industry. New media are a type of communication "from many to many", as opposed to media where communication is "from one to many". New media as a phenomenon of the modern information space, combine phenomena and processes that are different in nature and are changing dynamically. Their form is social media, characterized by interactivity and 
a large amount of content created by users. Social media as new channels of communication are gradually becoming the main drivers of change. Social media, more than traditional, focuses on discussion and the creation of new values. This is their natural property.

New media are transforming mediacultures, influencing not only traditional media, but the entire spectrum of social communications, changing their form and content and affecting daily life.

\section{REFERENCES}

1. Алферова 3. И., Алферов А. Н., Національне та європейське в сучасній українській медіаосвіті // Культура України. Сер. Мистецтвознавство : зб. наук. пр. / Харків. держ. акад. культури ; за заг. ред. В. М. Шейка. - Харків: ХДАК, 2016. - Вип. 53. - 372 с.

2. Appadurai A. Disjuncture and Difference in the Global Cultural Economy [Electronic resource] / Arjun Appadurai // Theory Culture Society. - 1990. - Vol. 7. - P. 295-310.

3. Бодріяр Ж. Симулякри і симуляція / Жан Бордіяр. - К.: «Основи», 2004. - $230 \mathrm{c.}$

4. Бурдье П. Социология политики / Пьер Бурдье // Социология политики; [пер. с фр. Н.А. Шматко]. - M.: Socio-Logos, 1993. -336 с.

5. Верховская С. Б. Медиакультура как фактор трансформации сознания // Вестник угроведения № 2 (5), 2011. Философия, сочиология, политология, С. 93-99.

6. Возчиков В. А. Философия образования и медиакультура информационного общества: дис. ... д-ра филос. : 09.00.11 / Вячеслав Анатольевич Возчиков. - Санкт Петербург, 2007. - 413 с.

7. Дебор Г. Общество спектакля / Ги Дебор; [пер. с фр. С. Офертаса и М. Якубович]. - М.: Логос, 1999. - 224 с.

8. Етимологічний словник української мови: В 7 т. - Т. 6: У-Я / Ред. кол.: О. С. Мельничук (гол. ред.), В. Т. Коломієць, Т. Б. Лукінова, Г. П. Півторак, В. Г. Скляренко, О. Б. Ткаченко; Укладачі: Г. П. Півторак, О. Д. Пономарів, І. А. Стоянов, О. Б. Ткаченко, А. М. Шамота. НАН України. Ін-т мовознавства ім. О. О. Потебні. К.: Наукова думка, 2012. - 568 с.

9. Землянова Л. М. Коммуникативистика и средства информации. Англо-русский толковый словарь концепций и терминов. Москва, 2004. $416 \mathrm{c}$.

10.Зубанова Л. Б. Современное медиапространство: подходы к пониманию и принципы интерпретации [Электронный ресурс] / Л. Б. Зубанова // Вестник Челябинской государственной академии 
культуры и искусств. - 2008. - № 2 (14). - С. 6-17. - Режим доступу : http://elibrary.ru/contents.asp?issueid=521114.

11.Кастельс М. Информационная эпоха: экономика, общество и культура / Мануэль Кастельс; [пер. с англ. под науч. ред. О. И. Шкаратана]. - М.: ГУ ВШЭ, 2000. - 608 с.

12. Kellner D. Media Culture: Cultural studies, identity and politics between the modern and postmodern / D. Kellner. - London ; New York, 2000. - 357 p.

13.Кириллова Н. Б. Что такое медиакультура // ТелеЦЕНТР. 2005. № 4 (12). С. 19-21.

14.Кириллова Н. Б. Многообразие культур в глобальном медиапространстве [Электронный ресурс] / Н. Б. Кириллова // Известия Уральского государственного университета. Сер. 2, Гуманитарные науки. - 2006. - № 47, Вып. 12. - С. 58-68. - Режим доступа : http:// hdl.handle.net/10995/23304.

15. Кулибаба С. И. Медиапространство и трансляция духовных ценностей [Электронный ресурс] / Сергей Иванович Кулибаба // Материалы Международ. науч. конф «Медиакультура новой России: методология, технологии, практики» / [под ред. Н. Б. Кирилловой и др.]. - 2007. - Т.2 - С. 125-134. - Режим доступа: http://vk.com/ doc-54830594_213541276.

16.Лассуєлл Г. Д. Психопатология и політика [Ел. рес.] / Г. Д. Лассуєлл. - Режим доступу: http://sbiblio.com/biblio/archive/ lasuel_psi

17. Липпман У. Общественное мнение / Уолтер Липпман; пер. с англ. Т. В. Барчунова, под ред. К. А. Левинсон, К. В. Петренко. М.: Институт Фонда «Общественное мнение», 2004. - 384 с.

18. Литвинович М. Как интернет меняет медиапространство. Интеллектуальная Россия. [Электронный ресурс] / Марина Литвинович // Интерлос. - Режим доступа: www.intelros.ru/intelros/reiting/ reyting_09/material_sofiy/8763-kak-internetmenyaetmediaprostranstvo. html.

19. Ляхов О. Доповідь на круглому столі, проведеному 22 листоп. 2012 р. в Києві за ініціативи Громадської Ради при Національній Раді України з питань телебачення та радіомовлення [Електронний pecypc] / О. Ляхов. Режим доступу : http:///www.nrada.dov.ua

20.Маклюэн Г. М. Понимание Медиа: Внешние расширения человека / пер. с англ. В. Николаева; закл. ст. М. Вавилова. М.-Жуковский: «КАНОН-пресс-Ц.», «Кучково поле», 2003. 464 с. 
21.Маклюэн М. Понимание медиа: внешние расширения человека [Электронный ресурс] / Маршалл Маклюэн; [пер. с англ. В. Николаева]. - М.: Канон-Пресс, 2003. - 458 с.

22. McLuhan M., Fiore Q. War and Peace in the Global Village. N.Y.: Bantam, 1968.

23. McQuail D. Mass Communication Theory / D. McQuail ; 6th edition. - London : SAGE, 2010. - 632 p.

24.Наумова М. Ю. Нові медіа та традиційні 3МІ: моделі співіснування / М. Ю. Наумова // Актуальні проблеми соиіології, психології, педагогіки. - 2011. - Вип. 13. - С. 86-92. - Режим доступу: http://nbuv.gov.ua/UJRN/apspp.

25.Пискун Т. В. Медиапространство как особая социальная структура: к методологии вопроса [Электронный ресурс] / T. В. Пискун // Режим доступа: www.readera.org/article/ medyeaprostranstvo-kak-osobaja-sotsyealnaja-0-10118474.

26. Проценко Д., Тупчієнко Д. «Огляд підходів до регулювання нових конвергентних аудіовізуальних засобів масової інформації: міжнародний досвід», К. 2012, 112 с.

27.Рашкофф Д. Медиавирус. Как поп-культура тайно воздействует на ваше сознание [Электронный ресурс] // Библиотека Гумер - гуманитарные науки. URL: http://www.gumer.info/ bibliotek_Buks/Gurn/Rashk.

28. Рогалева О. С. Новые Медиа: эволюция понятия (аналитический обзор) / О. С. Рогалева, Т. В. Шкайдерова. - Вестн. Омского ун-та, 2015. - № 1. - С. 222-225.

29. Судакова В. М С.24 Нові медіа в сучасному суспільстві: культурологічний вимір: монографія / Судакова В. М., М. Ю. Наумова та ін. - К.: Інститут культурології НАМ України, 2017. - 352 с.

30. Social Media and its Origins [Електронний ресурс] - Режим доступу до pecypcy: http://www.defence.gov.au/pathwaytochange/ Docs/SocialMedia/1.\%20Social\%20media\%20and\%20its\%20origins\% 20SM.pdf.

31. Waters M. Globalization / Malcolm Waters. - L.: Routledge. 1996. -185 p.

32. Webopedia / new media [Електронний ресурс]. - Режим доступу : http://www.webopedia.com/TERM/N/new_media.html.

33. Хоркхаймер М., Адорно Т. В. Диалектика просвещения. Филофоские фрагмен- ты / Макс Хоркхаймер, Теодор В. Адорно; [пер. с нем. М. Кузнецова]. - М.-СПб.: Медиум, Ювента, 1997. - 312 с. 
34. Черемушкина Е. Ф. Основоположник британських «культурных исследований» Ричард Хогарт. [Електронний ресурс] / Е. Ф. Черемушкина. - Режим доступу: http://study-english.info.

\section{Information about the author:}

\section{Uvarova T. I.,}

PhD in Arts, Associate Professor at the Department of arts and humanities studies, International Humanitarian University, 33, Fontanska Road St., Odessa, 65009, Ukraine 
NOTES 
NOTES 
NOTES 
Publishing house "Liha-Pres"

9 Kastelivka str., Lviv, 79012, Ukraine 44 Lubicka str., Toruń, 87-100, Poland

Printed by the publishing house "Liha-Pres"

Passed for printing: August 12, 2020.

A run of 150 copies. 